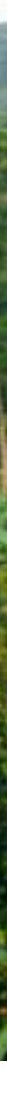

\title{
Opportunities for implementing REDD+ to enhance sustainable forest management and improve livelihoods in Lombok, NTB, Indonesia
}

$\begin{array}{lll}\text { Jae Soo Bae } & \text { Mansur Afifi } & \text { Jintaek Kang } \\ \text { Cheolmin Kim } & \text { Larry A. Fisher } & \text { Raehyun Kim } \\ \text { Yeon-Su Kim } & \text { Soo Min Lee } & \text { Jeong Soo Kim } \\ \text { Sitti Latifah } & \text { In-Ae Kim } & \end{array}$





\title{
Opportunities for implementing REDD+ to enhance sustainable forest management and improve livelihoods in Lombok, NTB, Indonesia
}

\author{
Jae Soo Bae \\ Korea Forest Research Institute (KFRI), Seoul, Republic of Korea \\ Cheolmin Kim \\ Korea Forest Research Institute (KFRI), Seoul, Republic of Korea \\ Yeon-Su Kim \\ Northern Arizona University (NAU), Flagstaff, AZ, USA \\ Sitti Latifah \\ University of Mataram (UNRAM), Mataram, Lombok, Indonesia \\ Mansur Afifi \\ University of Mataram (UNRAM), Mataram, Lombok, Indonesia \\ Larry A. Fisher \\ University of Arizona (UA), Tucson, AZ, USA \\ Soo Min Lee \\ Korea Forest Research Institute (KFRI), Seoul, Republic of Korea \\ Center for International Forestry Research (CIFOR), Bogor, Indonesia \\ In-Ae Kim \\ Korea Forest Research Institute (KFRI), Seoul, Republic of Korea \\ Jintaek Kang \\ Korea Forest Research Institute (KFRI), Seoul, Republic of Korea \\ Raehyun Kim \\ Korea Forest Research Institute (KFRI), Seoul, Republic of Korea \\ Jeong Soo Kim \\ Korea Forest Research Institute (KFRI), Seoul, Republic of Korea
}


Working Paper 151

@ 2014 Center for International Forestry Research

Content in this publication is licensed under a Creative Commons Attribution-NonCommercial-NoDerivs 3.0 Unported License http://creativecommons.org/licenses/by-nc-nd/3.0/

Bae JS, Kim C, Kim Y-S, Latifah S, Afifi M, Fisher LA, Lee SM, Kim I-A, Kang J, Kim R and Kim JS. 2014. Opportunities for implementing REDD + to enhance sustainable forest management and improve livelihoods in Lombok, NTB, Indonesia. Working Paper 151. Bogor, Indonesia: CIFOR.

ISBN 978-602-1504-44-4

Photo by Jintaek Kang/Korea Forest Research Institute

Forest of Mountain Rinjani, North Lombok, Indonesia

\author{
CIFOR \\ Jl. CIFOR, Situ Gede \\ Bogor Barat 16115 \\ Indonesia \\ $\mathrm{T}+62(251) 8622-622$ \\ $F+62(251) 8622-100$ \\ E cifor@cgiar.org
}

\title{
cifor.org
}

We would like to thank all donors who supported this research through their contributions to the CGIAR Fund. For a list of Fund donors please see: https://www.cgiarfund.org/FundDonors

Any views expressed in this publication are those of the authors. They do not necessarily represent the views of CIFOR, the editors, the authors' institutions, the financial sponsors or the reviewers.

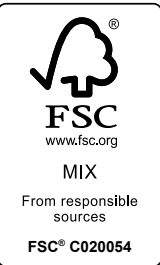




\section{Table of contents}

Abbreviations $\quad$ v

Acknowledgments

Preface viii

1 Introduction 1

2 Lombok: A general profile 6

Forest resources in Lombok 9

Forest governance and the KPHL RB 12

3 The evolution of forest governance in Lombok 13

The pre-colonial era: Indigenous management 13

Dutch colonial period 14

Early independence: 1945-1965 14

Central control: 1965-1998 15

Transition period: 1998-2002 16

Reducing Emissions from Deforestation and Forest Degradation (REDD+) 17

Other actors' role in forest management 18

4 Land-use change 21

Materials and methods 22

Results and discussion 23

KPHL Rinjani Barat

5 Estimation of carbon stock and carbon stock change 28

Methodology and data collection 28

Results and implications 30

6 Understanding drivers of deforestation and forest degradation 33

Methods

Factors driving deforestation and forest degradation 35

Conclusion 40

7 Reference emission level and compensation options 41

Estimating reference emission level 41

REDD+ compensation for climate mitigation: How and how much? 43

Conclusions

8 References 49 


\section{List of figures and tables}

\section{Figures}

1.1 Location maps of the KPHL RB in NTB province, Indonesia 2

1.2 Five elements of REDD project analysis $\quad 4$

2.1 Map of West Nusa Tenggara Province 9

4.1 Landsat satellite images of Lombok from 1990 to 2010 at 5-year intervals 22

4.2 Diagram of multi-date image classification and change detection 24

4.3 Land-use classification of Lombok from 1990 to $2010 \quad 25$

5.1 Location of the sample plots 29

5.2 Sample plot design $\quad 29$

6.1 Map of study village locations

\section{Tables}

2.1 Population change on Lombok Island $\quad 7$

2.2 Annual population growth rate (\%) of Lombok Island 7

2.3 Size, gender ratio, household and average family size of Lombok population in $2010 \quad 7$

2.4 Area, number of districts, sub-districts and villages in Lombok 8

2.5 NTB's GDP at 2000 constant prices for the business sector in 2009-2011 8

2.6 Comparison of total forest area data from Ministry of Forestry, NTB Provincial Planning Board
and NTB Provincial Forest Service

$\begin{array}{lll}2.7 & \text { Forest area by functional classification } & 10\end{array}$

2.8 Forest area in Lombok $\quad 10$

2.9 KPHs on Lombok $\quad 11$

2.10 KPHL Rinjani Barat 11

3.1 Summary of the evolution of forest governance in NTB 19

4.1 Satellite datasets used in the study 22

4.2 Land-use classification of Lombok, from 1990 to 2010 (ha) 24

4.3 Land-use and land-cover transition in Lombok, 1990 to $2010 \quad 26$

4.4 Land-uses of KPHL Rinjani Barat from 1990 to 2010 (ha) 26

$5.1 \mathrm{DBH}$ and height of trees by forest type $\quad 30$

5.2 Soil characteristics by forest type and soil depth 31

5.3 Carbon stock by land use type (tC/ha) 32

5.4 Carbon stock (tC/ha) in other studies

5.5 Carbon stock (tC/ha) changes by forest types (1990-2010) 32

6.1 Forest governance and forest functions of nearby forests for 14 FGDs and household survey locations 34

6.2 Population growth and deforestation rate by village (desa) 36

6.2 Population growth rates and forest change 36

6.3 Fuelwood demand within the study area 37

6.4 Adjudication of forestry-related offenses in NTB (2002-2011) 39

7.1 Annual areas of unplanned deforestation: Population driver approach (ha) 42

7.2 Land-use change and carbon stock changes 42

7.3 Projected emissions from fuelwood consumption in the project area 43

7.4 Potential market values of carbon emission reduction (US\$ millions) 44

7.5 Net present value of US $\$ 1$ million investment at 3\% discount rate over 30-year project period 44

7.6 Most commonly collected forest products and their market values 48

$\begin{array}{lll}7.7 & \text { Fuelwood consumption and market value } & 48\end{array}$ 


\section{Abbreviations}

A/R CDM

BAPPENAS

BAU

CDM

CIFOR

$\mathrm{DBH}$

DNPI

ETM+

FAO

FGD

GDP

GG

GHG

$\mathrm{HA}$

HD

HDI

$\mathrm{HH}$

$\mathrm{HKm}$

HL

HP

$\mathrm{HPH}$

$\mathrm{HPHH}$

HR

HTI

HTR

IPCC

$\mathrm{KPH}$

KPHL

KPHL RB

KOICA

MRV

MSS

NGO

NTB

PES

PRA

REDD

REDD+
Clean Development Mechanism for Afforestation and Reforestation

Badan Perencanaan Pembangunan Nasional (National Development Planning Board)

business as usual

Clean Development Mechanism

Center for International Forestry Research

diameter at breast height

Dewan Nasional Perubahan Iklim (National Council on Climate Change)

enhanced thematic mapper plus

Food and Agriculture Organization of the United Nations

focus group discussion

gross domestic product

gouvernement grond (government lands)

greenhouse gases

butan adat (customary forest)

butan desa (village forest)

Human Development Index

household

butan kemasyarakatan (community forest)

hutan lindung (protected forest)

hutan produksi (production forest)

hak pengusahaan hutan (forest enterprises)

hak pemungutan hasil hutan (forest harvest rights)

hutan rakyat (public forest)

hutan tanaman industri (industrial forest plantation)

butan tanaman rakyat (community plantation forest)

Intergovernmental Panel on Climate Change

kesatuan pengelolaan hutan (forest management unit)

kesatuan pengelolaan hutan lindung (protected forest management unit)

kesatuan pengelolaan hutan lindung Rinjani Barat (West Rinjani protected forest management unit)

Korea International Cooperation Agency

measurement, reporting and verification

Landsat multispectral scanner

nongovernmental organization

Nusa Tenggara Barat (West Nusa Tenggara)

payments for ecosystem services

participatory rural appraisal

Reducing Emissions from Deforestation and Forest Degradation

REDD and conservation and sustainable management of forests and enhancement of forest carbon stocks in developing countries 
REL reference emission level

TGHK tata guna hutan kesepakatan (consensus forest-use plan)

TM Landsat thematic mapper

UNFCCC United Nations Framework Convention on Climate Change

VCS Verified Carbon Standard

WRS worldwide reference system

WWF

World Wildlife Fund 


\section{Acknowledgments}

This research was performed as part of a unique collaboration between the Korea Forest Research Institute, the Center for International Forestry Research, the University of Mataram, Northern Arizona University and the University of Arizona. The authors are grateful for the support of many additional people and institutions during the research. Madani Mukarom, head of the KPHL Rinjani Barat, was involved from site selection to field inventory and social economic surveys, providing his personal insights and organizing technical and field support. Field assistance of many
KPHL Rinjani Barat and University of Mataram staff were also critical to the research effort. Abdul Hakim and staff at the NTB Provincial Forest Service provided essential guidance and access to necessary background reports and project documents. We are also grateful to Sunpil Jin and Kijoo Han, project managers at the Korea International Cooperation Agency (KOICA). Their experience in Lombok with the KOICA-sponsored Climate Change Mitigation project was essential in helping initiate our collaboration network in Lombok, a centerpiece of our research approach. 


\section{Preface}

REDD + refers to a newly established mechanism that aims to reduce greenhouse gas emissions from deforestation and forest degradation, and includes conservation, sustainable management of forests and enhancement of forest carbon stocks in developing countries; it enables developed countries to financially support REDD+ activities in developing countries through sustainable forest management. The Intergovernmental Panel on Climate Change (IPCC) has determined that REDD+ can be a very cost-effective policy option for mitigating climate change, with potential economic, social and other environmental co-benefits, if implemented sustainably. Reducing forest loss could therefore contribute to climate change mitigation, biodiversity conservation, and improved livelihoods for local communities.

However, in order to effectively implement REDD+ in developing countries, a number of constraints must be addressed. First, forest managers must develop the skills and methods to identify landuse change and estimate carbon stock change over time. Local technical capacity remains limited, and significant challenges remain in working effectively with forest margin communities and other local stakeholders. Developing effective forest governance and institutions is a critical aspect of designing and implementing successful REDD+ projects, as is the commitment to provide adequate and sustained financial support. In Indonesia, the development of more localized forest management units (KPHs) represents a promising opportunity to address these challenges.

The Korea Forest Research Institute (KFRI), together with the Center for International Forestry Research (CIFOR), Northern Arizona University (NAU), the University of Arizona, and the University of Mataram in Indonesia, have completed a REDD feasibility study on the island of Lombok, Indonesia, where there are high poverty rates, rapid population growth and complex social dynamics. This study was completed using the five essential elements: (1) identification of land-use changes, (2) estimation of average carbon stocks in forests and shrubland, (3) socioeconomic surveys to identify drivers of deforestation and forest degradation, (4) estimation of future reference emission levels, and (5) developing alternatives to reduce the rates of deforestation and forest degradation.

We hope the results of this study provide important insights for REDD+ implementation for scientists, policy makers, practitioners, and local communities as they work together in planning and implementing REDD+ projects.

Lombok KPH REDD Research Team 


\section{Introduction}

The world's forests decreased at a rate of 8.3 million ha per year during 1990-2000. Although the annual net forest loss decreased to 4.8 million ha during 2000-2005, it rose again to 5.6 million ha during 2005-2010 (FAO 2010). During 2005-2010, the area of tropical forest decreased rapidly in several developing countries, including Brazil $(2,194,000$ ha annual loss), Indonesia (685,000 ha), and Nigeria (410,000 ha); in Australia, severe drought and forest fires have exacerbated the loss of forest since 2000 (FAO 2010). Brazil and Indonesia together accounted for $52 \%$ of the world's net loss of forest during this same period. Especially, decrease of primary forests is particular concern, accounting for $38 \%$ of the 15.79 million ha of forest cover loss for Indonesia for the period 2000-2012 (Hansen et al. 2013). This forest loss has contributed significantly to greenhouse gas (GHG) emissions, with emissions from deforestation and decay of biomass accounting for approximately $17.4 \%\left(\mathrm{CO}_{2}\right.$ equivalent $)$ of the world's GHG emissions in 2004 (IPCC 2007a). The reversal of these trends of net tropical forest loss in developing countries would greatly contribute to mitigating climate change.

Reducing emissions from deforestation and forest degradation in developing countries (REDD) is a results-based mechanism currently under negotiation through the United Nations Framework Convention on Climate Change (UNFCCC). The REDD mechanism seeks to create financial value for reductions in emissions by offering incentives for developing countries to reduce emissions from forested lands and encourage investment in lowcarbon paths to sustainable development (UNREDD 2011). REDD+ extends beyond reducing deforestation and forest degradation to include the additional dimensions of conservation, sustainable forest management and enhancement of forest carbon stocks (UNFCCC 2010).

REDD+ activities were discussed under the UNFCCC as climate mitigation actions that would allow developing countries to be eligible to receive adequate and predictable financial and technical support from developed countries, as a reward for achieving real reductions in emissions (UNFCCC 2010). However, the eligibility of land use, land- use change and forestry activities under the Clean Development Mechanism (CDM) during the second commitment period (2013-2020) under the Kyoto Protocol does not include REDD+ activities (UNFCCC 2012). Since 2013, international negotiations under the UNFCCC have addressed REDD + as a component of a new post- 2020 climate change regime, instead of within the Kyoto Mechanism (UNFCCC 2012). The recent Warsaw REDD+ Framework clarified the structural design of REDD+ implementation, reducing uncertainties about the financial and technical support that developing countries can receive (UNFCCC 2012). A 2012 survey showed that many carbon market experts are optimistic that REDD+ credits will be permitted in California before 2020 and they will have equivalent status to the CDM under the UNFCCC umbrella by the same date (IETA 2012).

Indonesia features heavily in international discussions on REDD+ because its large expanse of tropical forest offers immense potential for reducing GHG emissions. In 2005, Indonesia was the third largest emitter of GHGs after the United States and China; approximately $85 \%$ of Indonesia's total GHG emissions are linked to land-use change and the forestry sector, including destruction of peatlands (Leitmann et al. 2009). The Indonesian Government has set an ambitious target for reducing the country's emissions: $26 \%$ below business-as-usual (BAU) levels by 2020, or $41 \%$ below BAU with international support (Norad 2011). According to this plan, more than $87 \%$ of Indonesias total emission reduction target will be attributable to the forestry sector and peatlands (ROI 2011). Consequently, although REDD+ modalities and procedures have not yet been fully developed under the UNFCCC, Indonesia not only has the most REDD+ readiness and demonstration activities in the world (Cerbu et al. 2010), but it has also received the largest portion of REDD+ funding, through both multilateral and bilateral channels (Simula 2010). Indonesia has great potential to receive funding from the international community, and REDD+ funding would constitute a significant contribution. The estimated market value for avoided deforestation for Indonesia (US\$108 million per year) exceeds the entire Ministry of Forestry budget (US\$102 million) for 2005 (Niles et al. 2002; Phelps et al. 2010). 


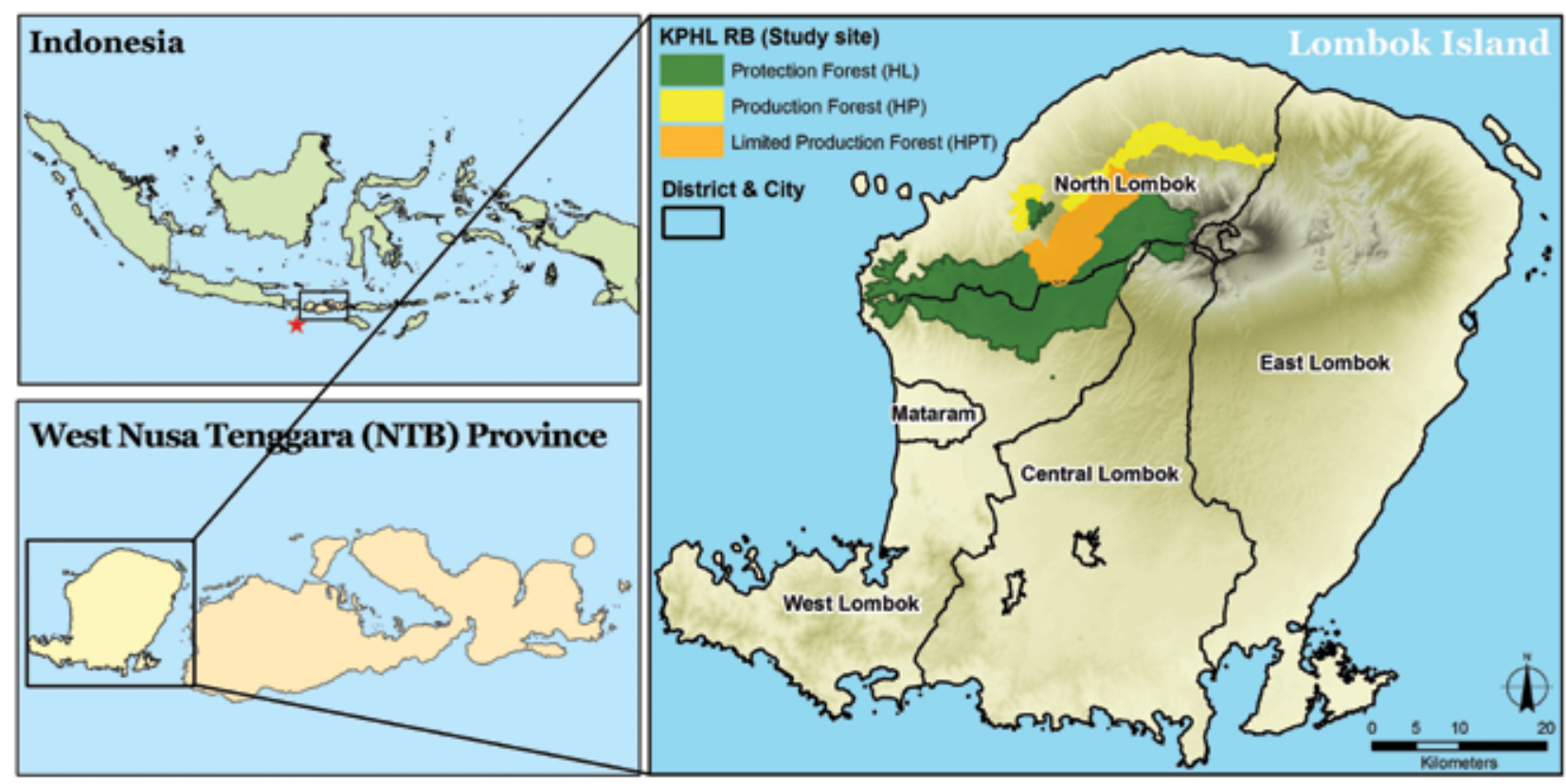

Figure 1.1 Location maps of the KPHL RB in NTB province, Indonesia

Due to the large forest reserves on Sumatra and Kalimantan, and their significant potential to reduce GHG emissions, more than two-thirds of the REDD+ projects conducted to date in Indonesia have occurred on these two islands. However, plans continue for expanded REDD+ programs through Indonesia's vast archipelago of more than 17,500 islands.

The work described in this paper focuses on the dynamics of deforestation and forest degradation on the island of Lombok, in West Nusa Tenggara (NTB) province (see Figure 1.1). We examine Lombok as a potential REDD site for several important reasons:

- NTB is an economically underdeveloped region that has the second-lowest Human Development Index $(\mathrm{HDI})^{1}$ nationally, ranked 32 nd out of Indonesia's 33 provinces (CAS 2014). NTB is considered less favorable for developing REDD+ projects since it has relatively low forest cover, limited financial revenues from forestry activities, and insufficient human resources and management capacity. For this reason, we anticipate opportunities not only to conserve forests but also to strengthen the capacity of various stakeholders through REDD+ project development.

1 The Human Development Index combines life expectancy, educational attainment and income into a composite indicator of development.
- The development of new and more localized forest management units (kesatuan pengelolaan butan or KPH) in Indonesia provides a unique opportunity to work more closely with forest margin communities in understanding the dynamics of deforestation and forest degradation. The Indonesian government has underscored the KPH's role in achieving sustainable forest management at the local level, and particularly in mitigating climate change impacts. In principle, KPHs can have greater familiarity with local conditions (stakeholders, forest status, concession operations and regulatory standards) - an advantage that endows them with the potential to play a critical role in resolving land-use conflicts within and among forest margin communities, and ensures the legitimacy and effectiveness of forest carbon projects (BAPPENAS 2009). In 2012, the West Rinjani Protected forest Management Unit (KPHL RB) in Lombok was recognized as one of the most successful KPHs among the 481 $\mathrm{KPH}$ in Indonesia.

- We also note the KPHL RB's high potential for reducing GHG emissions, given that the forests of Lombok have experienced historically high rates of deforestation (Bae et al. 2012). REDD+ projects have the potential for reducing a large proportion of GHG emissions on the island of Lombok. 
This paper explores opportunities for implementing REDD+ activities in the KPHL RB, with particular emphasis on the potential role of the $\mathrm{KPH}$ as an institutional partner in addressing the drivers of deforestation and forest degradation. In examining the feasibility for implementing REDD+ projects, we relied on five essential elements for our analysis (see Figure 1.2):

1. Identification of land-use changes in both the reference region and project area. As the term 'REDD' suggests, changes in deforestation and forest degradation must be clearly defined and quantified before initiatives to reduce these impacts are considered. Although a universal definition of 'forest' is still under debate (Sasaki and Putz 2009), we have chosen to follow general international guidelines, such as those established by IPCC and FAO, for assessing and monitoring human-induced carbon losses, in order to accurately and costeffectively follow carbon stock changes over time (Guariguata et al. 2009). Deforestation is generally understood to include the longterm or permanent loss of forest cover (FAO 2002) or the direct human-induced conversion of forested land to non-forested land (UNFCCC 2001). Forest degradation is a reduction of the canopy cover or stocking within the forest (FAO 2000). However, precise distinctions between deforestation and forest degradation are difficult to measure through remote sensing analysis when it progresses temporarily, and it requires careful field assessment and direct monitoring. For example, a forest crown cover decrease from $60 \%$ to below $10 \%$ during a project period would be categorized as deforestation. But any forest loss of over $10 \%$ of crown cover would be categorized as forest degradation, because even with its reduction in net carbon stock, the forest still remains.

The Verified Carbon Standard (VCS) requires identification of change in land use at least over 10 years. The IPCC (2006) suggests adopting six land use categories: forest land, cropland, grassland, settlements, wetlands and other land. Our research developed a landuse-change matrix of Lombok Island from 1990 to 2010 by analyzing Landsat imagery and classifying all land areas in accordance with these six landuse categories. We further classified forests into two major subcategories: primary forest and secondary forest, distinguishing these categories from shrubland, which often occurs after forest clear-cutting and in forest transition areas. Classifying shrubland as a distinct sub-class is unique to this study, based upon our analysis of the local context of landuse change. We categorized shrubland as a separate land use class, and noted the change from primary and secondary forest types into shrubland as the intermediate process of forest conversion to agricultural uses, identifying this change in both spatial and temporal dimensions.

2. Estimation of average carbon stocks in forests and shrubland. The IPCC (2006) recommends assessing forest carbon by evaluating carbon stocks in above- and belowground biomass, litter, deadwood and soil organic carbon. The assessment of biomass is generally a mandatory requirement for Afforestation/Reforestation Clean Development Mechanism (A/R CDM) and VCS. We determined a sample size for the survey of primary and secondary forests and shrubland, and developed a field survey manual, conducted training for KPH staff, and carried out forest inventory surveys in 45 sample plots to estimate forest carbon stock. Through this process, we obtained a quantitative assessment of carbon stocks for forests and shrublands within the KPHL RB.

3. Socioeconomic surveys to identify drivers of deforestation and forest degradation. Considerable discussions have focused on the direct and underlying drivers of deforestation (Angelsen 1995; Angelsen and Kaimowitz 1999; Geist and Lambin 2001). An understanding of local social and economic conditions, and livelihood strategies in forest margin communities is an essential element in assessing REDD+ project feasibility and readiness. Our socioeconomic research included an analysis of population census and other secondary data, as well as primary data collection in 14 administrative villages (desa) within the KPHL RB (Figure 6.1), using participatory rural appraisal (PRA) through focus group discussions and in-depth interviews with key informants, as well as household surveys. We used multiple methods to estimate the extent and degree of forest encroachment and to understand community forest-use dynamics that have contributed to deforestation and forest degradation. 


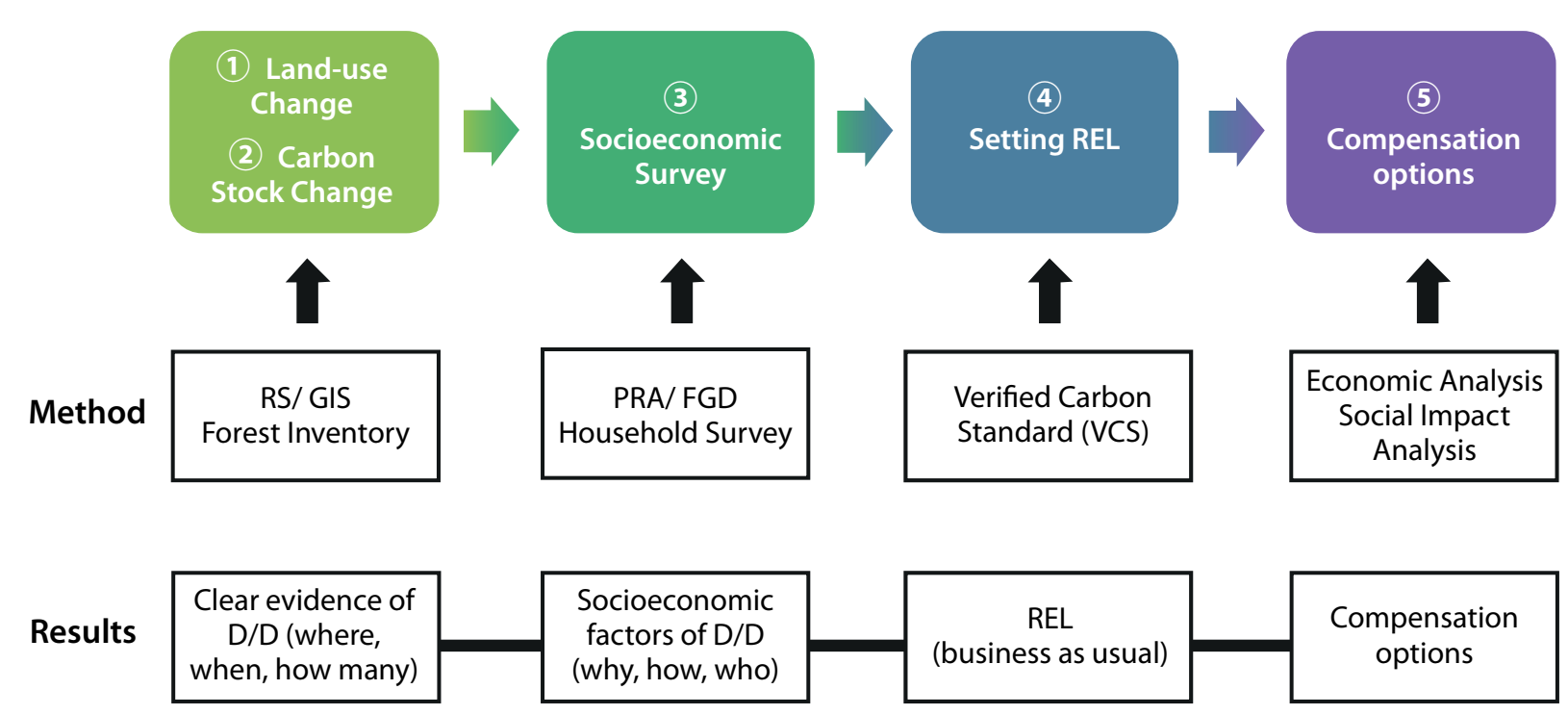

Figure 1.2 Five elements of REDD project analysis

Note: PRA (participatory rural appraisal), FGD (focus group discussion), REL (reference emission level)

Detection of land-use change, carbon stock change estimation, and socioeconomic surveys are complementary means for estimating and projecting carbon stock changes over time. Based on this deeper understanding of ecological and social changes in and around the KPHL RB, and in consultation with the KPHL RB and other local partners, we have proposed compensation options and policy alternatives for addressing deforestation and forest degradation.

4. Establishment of future reference emission levels (REL). For climate mitigation, simply reducing rates of deforestation and forest degradation is insufficient, since the amount of avoided emissions must be quantified and demonstrated. The reference emission level (REL) is the expected carbon emission rate from deforestation and forest degradation in the absence of interventions. Establishing a REL at the start of a project is necessary to determine what is being rewarded, how to measure success, and how to link project-level, subnational and national actions to international reporting (Ashton et al. 2009). We have generally followed VCS guidelines for estimating baseline carbon stock changes from unplanned frontier deforestation. We extrapolated future land-use changes based on population growth and projected new forest cultivation demand; we also projected carbon emissions from unsustainable fuelwood collection.
5. Developing alternatives to reduce the rates of deforestation and forest degradation. Based on lessons learned from other forest and biodiversity conservation projects, we have expanded the scope of analysis beyond the conventional definition of payments for ecosystem services (PES). We evaluated various options of rewards and coinvestments for ecosystem services, which include developing more secure land-tenure schemes and encouraging alternative energy sources. The ongoing challenge for this final phase of the study is to determine how to promote effective and equitable forest governance practices, while ensuring efficient reduction of deforestation and forest degradation that is results-based.

The paper discusses each of these elements in turn. Chapter 2 offers a general description of forest conservation and development in Lombok, including demographics, geography, politics, economics and resources. Chapter 3 provides a general history of forest governance in Indonesia and in Lombok, with particular emphasis on the more recent introduction of the local KPHs. Chapter 4 presents our analysis of land-use changes in Lombok (Element \#1), with a special focus on the KPHL RB, while Chapter 5 provides estimates of average carbon stocks in forests and shrublands (Element \#2). In Chapter 6, we present the results of the socioeconomic surveys, examining the drivers of deforestation and forest degradation (Element \#3). Chapter 7 assesses REL (Element \#4), offers recommendations on alternative 
incentive and compensation schemes (Element \#5) and discusses the challenges and opportunities in addressing deforestation and forest degradation in Lombok.

Our main objective in conducting this research has been to contribute to the growing body of experience and literature for developing sustainable and replicable approaches for promoting co-investment in environmental conservation, particularly in areas with complex social dynamics. We hope that our analysis - particularly the use of mixed research methods combining remote sensing analysis, field surveys, and both participatory and more conventional socioeconomic research methods - will yield important methodological insights for REDD+ researchers and practitioners. Our findings highlight the importance of strengthening local capacity to manage, monitor and provide incentives that reflect the social values of ecosystem services, including enhancing intermediaries' capacity for effective collaboration.

However, as we note in our conclusions, the most important lesson from this analysis is the pivotal role of the $\mathrm{KPH}$ as a viable forest governance structure for implementing these projects.

The KPHL RB was a key consideration in selecting the project area for this initial stage of the REDD+ feasibility study, and KPHL RB staff have been essential partners in sharing data and information, in conducting field research, and in consultations with local communities. In the land-use change and carbon stock change analysis, and in the participatory socioeconomic surveys, the KPHL RB provided leadership support and validation for the analysis, conclusions, and recommendations, based on their on-site knowledge, experience and relationships. The information presented here serves as an essential resource for the KPHL RB in establishing shortand long-term forest management plans, and the accumulated information from this research also provides the foundation for a long-term forest information management system.

Despite the significant contributions of the KPHL $\mathrm{RB}$ in West Lombok, and the high expectations for the role of $\mathrm{KPH}$ in REDD+ implementation in Indonesia, the national capacity for $\mathrm{KPH}$ s to fulfill this role remains limited (Bae et al. 2014), and it is unrealistic to assume that the Indonesian Government can instantly address this need. Indonesia has committed to prioritizing the $\mathrm{KPH}$ system because it serves as a basic tool for building local capacity, improving working relationships with forest margin communities and other local stakeholders, and represents a more flexible and localized approach to forest governance. Nevertheless, a commitment to capacity building and adequate financial support are critical aspects in the early development of the KPH system. In particular, the national government must provide sufficient training and funding to enable the $\mathrm{KPH}$ s to implement their most basic tasks: forest inventory and forest management planning.

The national government can also help connect more advanced KPHs and REDD+ project developers by working to create and promote close working partnerships between REDD+ activities and the KPH. Finding reliable partners is a common and critical challenge for REDD+ project developers in Indonesia because, although the forests belong to the Indonesian government, much of the forest estate is managed by local jurisdictions, and by indigenous peoples and local communities through their customary laws. No specific regulations yet exist to guide the distribution of monetary and non-monetary benefits from REDD+ activities, and accessing information on forest resources in Indonesia remains challenging. In this context, the KPHs that oversee clearly defined forest areas can function as reliable partners for REDD+ project developers and the many affected local stakeholders. Development and implementation of REDD+ activities can also support the KPHs in fulfilling their fundamental tasks in relation to forest inventory and forest management planning. A collaboration of this nature, complemented by technical and financial support from developed countries, can help local KPHs gather more precise forest information and develop more effective forest management plans, and these survey results and plans will be valuable assets for future REDD+ projects. 


\section{Lombok: A general profile}

Lombok is one of two main islands in the province of West Nusa Tenggara (NTB), sandwiched between Bali and the Lombok Strait in the west, and Sumbawa and the Alas Strait in the east (see Figure 2.1). Lombok's topography is dominated by the Mount Rinjani volcanic complex, located in the north-central part of the island and rising to $3726 \mathrm{~m}$, making it the second highest volcano in Indonesia, and the nation's third highest mountain. Central Lombok is hilly, sloping to the relatively flat relief in the southern part of the island. The island is about $70 \mathrm{~km}$ across, with a total area of $4738 \mathrm{~km}^{2}$ (BPS 2012).

Annual precipitation varies greatly by geography, ranging from $400 \mathrm{~mm}$ in the eastern and southern parts of the island, to $4250 \mathrm{~mm}$ in the west and north. Humidity is relatively high, averaging $81 \%$ (Idris et al. 2010, 2011; Fachry et al. 2011).

The 2010 Census reported the population of NTB province at 4.5 million, with 1.25 million households and an average of 3.59 family members per household (see Table 2.1). Seventy percent of NTB's population resides on the island of Lombok, although the island is only about a quarter of the province's total land area. Northern and western Lombok show generally lower population densities and higher forested areas than other parts of the island. Lombok's annual population growth rate decreased from $2.31 \%$ during $1971-1980$ to $1.12 \%$ during $2000-2010^{2}$ (this generally attributed to successful family planning and improved health service programs); however, the population of Lombok has continued to increase significantly during the last three decades, doubling from 1.6 million in 1971 to 3.2 million in 2010. Population growth rates are comparatively higher in West Lombok and Mataram City (see Table 2.2). Urban areas, in particular, have expanded dramatically during this time, increasing five-fold in NTB province (Fachry 2011).

Based on age classification, the population profile in NTB during 2000-2010 is dominated by children under the age of 14; gender distribution is somewhat

2 These growth figures are below the provincial and national rates $(1.17 \%$ and $1.47 \%$, respectively). evenly balanced, with slightly higher numbers of women (see Table 2.3).

Based on census figures for Lombok in 2010, more than 1.6 million people (51.8\%) lived in rural areas (BPS 2012). The World Wildlife Fund (2006) reported that 600,000 people live in the upland areas surrounding Mount Rinjani and are dependent on forest resources for their livelihoods. With population growth rates at $1.7 \%$, it is estimated that the pressure on these limited forest resources will continue to increase.

There are three major ethnic groups in NTB province, the Sasak, Samawa and Mbojo people, with additional populations of Balinese, Javanese and other migrants. Sasak is the indigenous and majority ethnic group on the island of Lombok, comprising more than $90 \%$ of residents, while Samawa and Mbojo people originate from neighboring Sumbawa Island. The traditional language of Lombok is Sasak, which is derived from Javanese and Balinese. More than 96\% of Lombok's residents are Muslim (BPS 2012).

Lombok society remains strongly traditional, with deeply held cultural values and the continued active role of local institutions. Customary and community-based regulations (or awiq-awiq) remain an important aspect of social life, and while largely an oral tradition, continue to bind local community structure and tradition. In many communities, the awiq-awiq related to forest management are still upheld in protected customary forests (butan adat).

Local leaders also retain strong influence within Lombok communities. In North Lombok, traditional adat leaders (such as mangku), continue to play an important role in society, while in other parts of Lombok, the religious leaders (or tuan guru) exercise strong influence. However, changing social and cultural values over the past few decades have brought new influences, particularly in terms of economic development. Despite these changes and the impact of the formal political structure, local culture and institutions still play an important role in the development of local and district regulations and social structure (Sukardi 2009; Fachry 2011). 
Table 2.1 Population change on Lombok Island

\begin{tabular}{lrrrrr}
\hline District & 1971 & 1980 & 1990 & 2000 & \multicolumn{1}{c}{2010} \\
\hline West Lombok & 510,068 & 654,878 & $583,907^{*}$ & 665,749 & $599,986^{*}$ \\
Central Lombok & 477,262 & 576,910 & 678,746 & 745,578 & 860,209 \\
East Lombok & 594,725 & 725,340 & 865,283 & 973,296 & $1,105,582$ \\
North Lombok & - & - & - & - & $200,072^{*}$ \\
Mataram City & - & - & 275,089 & 315,738 & 402,843 \\
Lombok Island & $1,582,055$ & $1,957,128$ & $2,403,025$ & $2,700,361$ & $3,168,692$ \\
\hline
\end{tabular}

* Mataram City and North Lombok district were separated from West Lombok in 1986 and 2008, respectively. Sources: BPS 2012; Population Censuses 1971, 1990, 2000 and 2010 (Fachry et al. 2011)

Table 2.2 Annual population growth rate (\%) of Lombok Island

\begin{tabular}{lcccc}
\hline District & $\mathbf{1 9 7 1 - 1 9 8 0}$ & $\mathbf{1 9 8 0 - 1 9 9 0}$ & $\mathbf{1 9 9 0 - 2 0 0 0}$ & $\mathbf{2 0 0 0 - 2 0 1 0}$ \\
\hline West Lombok & 2.80 & 2.75 & 1.40 & 1.50 \\
Central Lombok & 2.11 & 1.64 & 0.98 & 0.94 \\
East Lombok & 2.19 & 1.78 & 1.18 & 0.78 \\
North Lombok & & & 1.09 & 0.94 \\
Mataram City & & & 1.44 & 1.97 \\
Lombok Island & 2.31 & 2.01 & 1.17 & 1.12 \\
NTB & 2.36 & 2.15 & 1.34 & 1.17 \\
\hline
\end{tabular}

Source: BPS (NTB Statistics 2011)

Table 2.3 Size, gender ratio, household and average family size of Lombok population in $\mathbf{2 0 1 0}$

\begin{tabular}{lrrrrrr}
\hline \multirow{2}{*}{ District } & \multicolumn{3}{c}{ Population } & $\begin{array}{c}\text { Gender } \\
\text { ratio* }\end{array}$ & Household & $\begin{array}{c}\text { Family } \\
\text { size }\end{array}$ \\
\cline { 2 - 4 } West Lombok & 293,528 & 306,458 & 599,986 & 95.78 & 168,813 & 3.55 \\
Central Lombok & 407,079 & 453,130 & 860,209 & 89.84 & 259,968 & 3.35 \\
East Lombok & 515,148 & 590,434 & $1,105,582$ & 87.25 & 324,424 & 3.41 \\
North Lombok & 98,667 & 101,405 & 200,072 & 97.30 & 55,546 & 3.60 \\
Mataram City & 199,332 & 203,511 & 402,843 & 97.95 & 110,184 & 3.66 \\
Lombok Island & 1513,754 & 1654,938 & $3,168,692$ & 91.47 & 918,935 & 3.46 \\
NTB & 2183,646 & 2316,566 & $4,500,212$ & 94.26 & $1,252,581$ & 3.59 \\
\hline
\end{tabular}

* Gender ratio $=$ number of males per 100 females

Source: BPS 2012

NTB province is administratively divided into eight districts (kabupaten), two cities, 116 subdistricts (kecamatan), and 1117 villages (desa), while Lombok consists of four districts and one metropolitan area (Mataram City). Prior to 1986, Lombok was divided into three districts: West Lombok (Lombok Barat), Central Lombok
(Lombok Tengah) and East Lombok (Lombok Timur). Mataram City was separated from West Lombok in 1986, and in 2008 West Lombok district was further divided to establish the district of North Lombok. The current number of sub-districts and villages in Lombok is 53 and 592, respectively (NTB Statistics 2012). 
NTB province ranked the second lowest among 33 provinces in Indonesia in the Human Development Index (HDI). The lowest HDI in Lombok was in North Lombok district: 57.79 in 2008, rising slightly to 60.93 in 2011 . This figure reflects a life expectancy of 60.94 years, a literacy rate of $76.97 \%$, an average 5.60 years of schooling, and per capita annual expenditure of IDR 615,900 (or approximately US\$55 at current exchange rate). The latest figures (BPS 2012, Table 2.4) indicate that Mataram City also ranked highest in HDI (life expectancy, 67.13 years; $91.85 \%$ literacy rate, 9.22 years schooling, per capita annual expenditure,
IDR 648,010 or US\$ 57.86). Although the average income per capita of Lombok is lower than that of NTB province as a whole, Mataram City had the highest per capita expenditure in NTB in 2010 (BPS NTB 2012).

Table 2.5 presents an overview of NTB's economy and the contribution of each sector to the gross domestic product (GDP) of NTB. The largest contribution is from the agricultural sector $(24.3 \%)$, which employs about half of the population (44\%, based on 2007 figures), followed by mining (20.7\%), and trade/hotels/restaurants (16.2\%) (BPS 2012).

Table 2.4 Area, number of districts, sub-districts and villages in Lombok

\begin{tabular}{lccccc}
\hline $\begin{array}{l}\text { District } \\
\text { (Kabupaten) }\end{array}$ & Area $\left(\mathbf{k m}^{2}\right)$ & $\begin{array}{c}\text { Sub district } \\
\text { (Kecamatan) }\end{array}$ & $\begin{array}{c}\text { Village } \\
\text { (Desa) }\end{array}$ & $\begin{array}{c}\text { 2010 Adjusted per } \\
\text { capita income (USD)* }\end{array}$ & $\begin{array}{c}\text { Human Development } \\
\text { Index (2011) }\end{array}$ \\
\hline West Lombok & 1054 & 10 & 124 & 656.6 & 62.50 \\
Central Lombok & 1208 & 12 & 139 & 539.4 & 61.66 \\
East Lombok & 1606 & 20 & 246 & 562.2 & 63.93 \\
North Lombok & 810 & 5 & 33 & 705 & 60.93 \\
Mataram City & 61 & 6 & 50 & 1199 & 72.83 \\
Lombok Island & 4739 & 53 & 592 & 669 (NTB) & 66.23 (NTB) \\
\hline
\end{tabular}

Source: BPS NTB (2012)

Table 2.5 NTB's GDP at 2000 constant prices for the business sector in 2009-2011

\begin{tabular}{clrrrrrr}
\hline Category & Sector & 2009 (USD) & \% GDP & 2010 (USD) & \% GDP & 2011* (USD) & \% GDP \\
\hline 1 & Agriculture & 448,577 & 23.8 & 454,538 & 22.6 & 472,667 & 24.3 \\
1.1 & Food crops & 267,419 & 14.2 & 269,604 & 13.4 & 283,269 & 14.6 \\
1.2 & Estate crops & 52,377 & 2.8 & 51,426 & 2.6 & 51,657 & 2.7 \\
1.3 & Livestock & 66,308 & 3.5 & 68,508 & 3.4 & 70,606 & 3.6 \\
1.4 & Forestry & 1,290 & 0.1 & 1,308 & 0.1 & 1,346 & 0.1 \\
1.5 & Fishery & 61,183 & 3.2 & 63,692 & 3.2 & 65,789 & 3.4 \\
2 & Mining/Quarrying & 490,587 & 26.0 & 549,111 & 27.4 & 403,204 & 20.7 \\
3 & Manufacturing & 90,995 & 4.8 & 94,425 & 4.7 & 97,377 & 5.0 \\
4 & Electricity/Gas/Water & 6,676 & 0.4 & 7,171 & 0.4 & 7,762 & 0.4 \\
5 & Construction & 145,795 & 7.7 & 150,958 & 7.5 & 158,722 & 8.2 \\
6 & Trade/Hotels/Restaurants & 275,020 & 14.6 & 293,950 & 14.6 & 315,192 & 16.2 \\
7 & Transportation/ & 140,985 & 7.5 & 150,818 & 7.5 & 162,288 & 8.4 \\
& Communication & & & & & & \\
8 & Finance/Real estate/ & 97,264 & 5.2 & 102,593 & 5.1 & 113,086 & 5.8 \\
& Business Services & & & & & & \\
9 & Services & 191,542 & 10.1 & 203,425 & 10.1 & 212,930 & 11.0 \\
& NTB Total GDP & $\mathbf{1 , 8 8 7 , 4 4 1}$ & 100.0 & $\mathbf{2 , 0 0 6 , 9 8 9}$ & $\mathbf{1 0 0 . 0}$ & $\mathbf{1 , 9 4 3 , 2 2 9}$ & 100.0 \\
\hline
\end{tabular}

Source: (BPS 2012) (Note that 2011 figures are reported as "preliminary") 


\section{Forest resources in Lombok}

Indonesian Law Number 41/1999 defines 'forest' as an ecosystem unit or natural area dominated by trees and an integral element of the natural environment, while 'forest area' is defined as a particular area designated or classified by the government as permanent forest. Data on the extent of forest area in Indonesia therefore includes forest areas that have been designated and set aside administratively, as opposed to the biophysical definition of forest. This means that figures on forest area in Indonesia do not necessarily represent actual forest cover.

The Indonesian Government classifies forest area based upon the following functional considerations:

- production forest or forests whose primary function is providing forest products;

- protected forest or forests whose principal function is ecosystem protection, for example buffer, water management, flood protection, erosion control, preventing salt water intrusion and maintenance of soil fertility;

- conservation forest or forests with specific characteristics whose main function is biodiversity and ecosystem conservation.

Data on forest area in Nusa Tenggara Barat and Lombok varies considerably by source. Statistics reported by the national Ministry of Forestry, the provincial government and the provincial-level Forest Service are inconsistent, and the figures have also changed over time. For example, the Ministry of
Forestry reported a total forest area of $1,063,273$ ha in $1982,1,021,566$ ha in $1999,1,046,959$ ha in 2009, and 1,071,723 ha in 2011 (see Table 2.6).

Note that the discrepancies in forest area reported above and in subsequent tables are likely due to several factors: (1) differences in the use of base maps (e.g. from the National Topographic Map (Rupa Bumi Indonesia) to the Basic Forest Map (Peta Dasar Tematik Kehutanan)), (2) adjustments in forest boundaries, functions and uses, consistent with development and change within NTB, (3) definition and classification of forests based on the interpretation of satellite images, (4) the result of continued revisions of forest boundaries, and (5) technological advances in the use of remote sensing that allow for more detailed evaluation of forests and landscapes.

The most recent data from the NTB Provincial Forest Service reports that NTB province has $1,071,723$ ha forest area $(53 \%$ of the total area of the province). The forest classification (Table 2.7) includes 173,182 ha conservation forest, 449,141 ha protected forest, 289,313 ha limited production forest, and 160,085 ha production forest in total (Dinas Kehutanan Provinsi NTB 2011).

About $15 \%$ of the forest area in NTB is on the island of Lombok (see Table 2.8). Conservation and protected forests comprise more than $80 \%$ of the total forest area on Lombok, spreading across the four rural districts (Mataram City has no designated

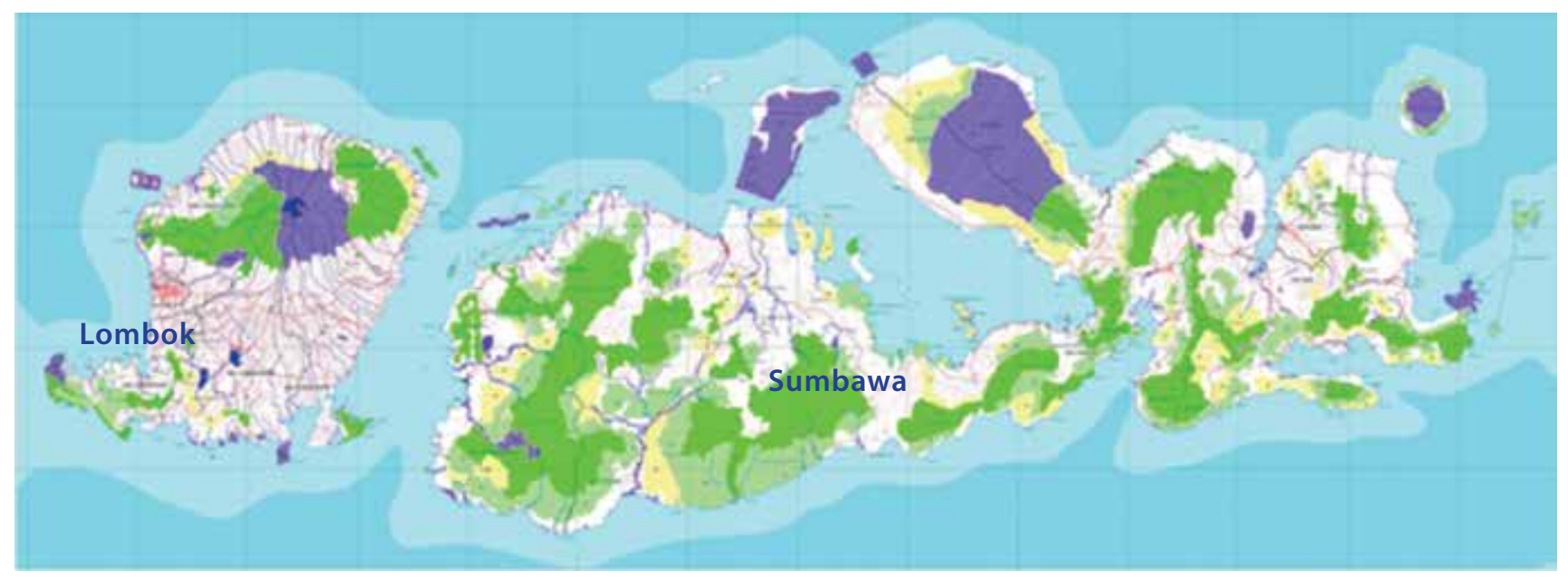

\section{Figure 2.1 West Nusa Tenggara Province}

Note: Protected forests are in bright green, production forests in light green, conservation forests in purple. 
Table 2.6 Comparison of total forest area data from Ministry of Forestry, NTB Provincial Planning Board, and NTB Provincial Forest Service

\begin{tabular}{lccc}
\hline & MoF & NTB Planning Board & NTB Forest Service \\
\hline 1982 & $1,063,273.3$ & - & - \\
1999 & $1,021,566.0$ & - & - \\
2009 & $1,046,959.0$ & $1,069,997.78$ & $1,069,997.78$ \\
2011 & $1,071,722.8$ & $1,069,997.78$ & $1,071,722.83$ \\
\hline
\end{tabular}

Sources: Ministry of Forestry (1982, 1999, 2009, 2011); Bapedda Provinsi NTB $(2009,2011)$

Table 2.7 Forest area by functional classification

\begin{tabular}{|c|c|c|c|c|c|c|}
\hline \multirow{2}{*}{ Forest class } & \multicolumn{4}{|c|}{ Forest area (ha) } & \multirow{2}{*}{ Non forested (ha) } & \multirow{2}{*}{ Total (ha) } \\
\hline & Primary & Secondary & Planted & Total & & \\
\hline Conservation & 35,626 & 124,655 & - & 160,281 & 12,901 & 173,182 \\
\hline Protection & 320,730 & 96,849 & - & 417,579 & 31,562 & 449,141 \\
\hline $\begin{array}{l}\text { Limited } \\
\text { production }\end{array}$ & 109,212 & 104,974 & 2.450 & 216,636 & 72,677 & 289,313 \\
\hline Production & 49,897 & 28,596 & 17.545 & 96,038 & 64,048 & 160,085 \\
\hline Total & 515,465 & 355,074 & 19.995 & 890,534 & 181,188 & $1,071,723$ \\
\hline
\end{tabular}

Source: Dinas Kehutanan Provinsi NTB (2011)

Table 2.8 Forest area in Lombok

\begin{tabular}{|c|c|c|c|c|c|c|}
\hline \multirow[b]{2}{*}{ District } & \multicolumn{4}{|c|}{ Forest Function (ha) } & \multirow[b]{2}{*}{ Forest area } & \multirow[b]{2}{*}{ Percentage (\%) } \\
\hline & Conservation & Protected & $\begin{array}{l}\text { Limited } \\
\text { production }\end{array}$ & Production & & \\
\hline West Lombok & $6,557.27$ & $25,078.94$ & $10,041.00$ & 304.69 & $41,981.90$ & 25.70 \\
\hline Central Lombok & $5,824.29$ & $9,926.14$ & - & $4,583.89$ & $20,334.32$ & 12.40 \\
\hline East Lombok & $27,445.00$ & $31,498.67$ & - & $5,565.00$ & $64,508.67$ & 39.50 \\
\hline North Lombok & $13,164.00$ & $11,198.22$ & $6,984.38$ & $5,171.52$ & $36,518.12$ & 22.40 \\
\hline Mataram & - & - & - & - & - & - \\
\hline Lombok Island & $52,990.56$ & $77,701.97$ & $17,025.38$ & $15,625.10$ & $163,343.01$ & 100.00 \\
\hline
\end{tabular}

Source: NTB Forest Agency Statistics (2011)

forest area), with the greatest portion located in the eastern part of the island. The total area of 163,434 ha also includes some protected and production forests designated for research and education. As noted above, the total forest area does not represent all areas of forest cover as defined in Law Number 41/1999. For example, even though it is classified as a marine conservation area, Gili Matra (2954 ha) remains under the jurisdiction of the Ministry of Forestry (NTB Forest Statistics 2011; WWF 2008).

Of the 163,343 ha of total forest area in Lombok, approximately $25 \%$ (40,101 ha) is classified by the NTB Government as in 'critical' (or degraded) condition, with more than $70 \%$ of this area $(30,909 \mathrm{ha})$ located in the districts of North and East Lombok. The most seriously affected forests are those in Sekaroh and Sambelia (East Lombok), and Mareje Bunga (Central Lombok), largely due to widespread forest clearing for agriculture, and in Sekotong (West Lombok, primarily due to expanded mining operations) (Dinas Kehutanan Provinsi NTB 2011).

Lombok is located on the eastern side of the Wallace Line, with flora and fauna considered part of a transitional zone between the mainland Southeast 
Table 2.9 KPHs on Lombok

\begin{tabular}{lcll}
\hline KPH & Area (ha) & Legal Foundation & Authority \\
\hline $\begin{array}{l}\text { Unit I KPHL Rinjani Barat (KPHL } \\
\text { Model Rinjani Barat) }\end{array}$ & 40,983 & MoF Decree 785/Menhut-II/2009 & NTB (North and West \\
Unit II KPHP Pelangan & & & Lombok Districts) \\
Unit III KPHL Tastura & 19,636 & - & West Lombok \\
Unit IV KPHL Rinjani Timur & 16,153 & MoF Decree No. 971/Menhut-II/2013 & Central Lombok \\
KPHK Rinjani National Park & 37,589 & Mof Decree No. 225/Menhut-II/2012 & East Lombok \\
KPHK Lombok & 41,330 & MoF Decree No. 781/Menhut-II/2009 & Ministry of Forestry \\
\hline
\end{tabular}

Source: BKSDA NTB (2012)

Table 2.10 KPHL Rinjani Barat

\begin{tabular}{llcccc}
\hline \multirow{2}{*}{ No. } & Forest unit & \multicolumn{3}{c}{ Forest Class (ha) } & \multirow{2}{*}{ Total (ha) } \\
\cline { 3 - 5 } & & Protection & Limited production & Production & \\
\hline 1. & Gunung Rinjani (RTK 1) & 28,278 & 6,997 & 4,335 & 39,610 \\
2. & Pandan Mas (RTK 2) & 630 & - & 740 & 1,370 \\
3. & Ranget (RTK 6) & 2.7 & - & - & 2.7 \\
Total & & 28,911 & 6,997 & 5,075 & 40,983 \\
\hline
\end{tabular}

Source: KPH Rinjani Barat (2012)

Asia and Papua-Australia systems. Forest types on Lombok include lowland and upland rainforests, mangroves, savannahs and mixed grasslands. The main forest species in this transitional zone include the dipterocarps, principally Dipterocarpaceae recutus and Casuarina junghubniana (BAPPENAS 2003; WWF 2004). Several important faunal species include mammals such as the Sunda fruit bat (Acerodon macklotii) and long-tailed macaques (Macaca fasciocularis); birds such as the Rinjani scops owl (Otus jolandae), Brahminy kites (Haliastur indus) and scaly-crowned honeyeater (Lichmera lombokia); reptiles such as the water monitor lizard (Varanus salvator) and gecko (Gekko gecko); amphibians such as the green frog (Rana erythrea); and a variety of insects, including beetles (e.g. Prosopocolius sp.) and butterflies (Cethosia sp., Papilio sp.). Forest-related flora includes rosewood (Dalbergia latifolia), kusum or soapberry (Schleichera oleosa), kalanggo (Duabanga moluccana), Malabar ebony or kelicung (Dyospiros malabarica), nyamplung (Callophyllum inophyllum), bajur (Pterospermum javanicum), gaharu (Gyrinops verstegii) and candlenut (Aleurites moluccana).

Lombok forests are also rich in non-timber forest products, which are used in a variety of local industries; these include bamboo (Bambusa sp.), ferns (Lygodium circinnatum), palm sugar (Arenga pinnata) and mimba or neem (Azadirachta indica) (BKSDA 2012).

The forest plays an extremely important role in the lives of local communities in Lombok. With more than $80 \%$ of the forest area classified as protected or conservation forest, Lombok's forests provide a critical array of ecosystem products and services, including water, food, timber, many important non-timber forest products (including medicinal plants), as well as regulatory services such as erosion control and flood mitigation, air quality, pollination of major economic crops, pest and disease control, maintenance of important habitat for biological and genetic diversity, cultural benefits such as ecotourism and recreation, and many other educational and spiritual values.

The forests surrounding Mount Rinjani constitute the primary watershed for $90 \%$ of all rivers on the island. These forests, and their waterfalls, vistas and wildlife, and the unique Segara Anak Lake within the volcanic cone have more recently become important as major international tourist destinations. As noted above, many non-timber forest products provide the primary material 
for many local household needs and livelihoods: bamboo, honey, rattan, palm sugar, furniture and construction materials. Customary forests (butan adat) are a fundamental aspect of local culture and religious history that continue to enrich the lives of local communities.

\section{Forest governance and the KPHL RB}

Ministry of Forestry Decree 337/Menhut-II/2009 established 29 Forest Management Units (KPHs) in NTB province, including 12 Protection KPHs, 11 Production KPHs and 6 Conservation KPHs. The management authority for the protected and production forests lies with the local government, while conservation forests (KPHK) remain under the jurisdiction of the national government. Six of the $29 \mathrm{KPH}$ in NTB province are located in Lombok (see Table 2.9).

The KPHL RB is considered a model KPHs for Indonesia. Covering an area of 40,983 ha, it spans the districts of North and West Lombok, encompassing 9 sub-districts, 38 villages and 104 hamlets. The KPH has jurisdiction over three forest units: Mount Rinjani (RTK 1), Pandan Mas (RTK 2) and Ranget (RTK 6), which include protected forest $(28,911 \mathrm{ha})$, limited production forest $(6,997 \mathrm{ha})$ and production forest $(5,075$ ha) (see Table 2.10).

In the NTB provincial land-use planning documents, the KPHL RB is described as a strategic area for tourism development, due to its position along the coastal zone of North Lombok, its natural beauty, and the fact that it is the point of departure for trekking expeditions into Mount Rinjani, with its five waterfalls, unique scenery and wildlife habitat. Given its proximity to the major population center (Mataram City), the KPHL RB is also the source of many economically important forest industries, including timber and fuelwood, as well as nontimber forest products such as coffee, cacao, coconut, jackfruit, durian, and a range of products that support local handicraft industries (BAPEDDA 2011; KPHL Rinjani Barat 2012). 


\section{The evolution of forest governance in Lombok}

\section{The pre-colonial era: Indigenous management}

Very little is known about access, use and community management of forests prior to the arrival of the Dutch. Much of the forests in Lombok were certainly under local management and subject to traditional or customary (adat) control. According to Kraan (2009), the forests surrounding Mount Rinjani and Segara Anak Lake were regarded as sacred by both Sasak and Balinese cultures. These forests were used primarily for religious rites and ceremonies, and a variety of cultural practices, including hunting, by the kings and local leaders who ruled the area during that time. Yudilastiantoro and Sulistyo (2008) report that 30 customary forests (butan adat) are still recognized in Lombok (29 in North Lombok and one in East Lombok) and, in these forests, community-based management has continued, having been passed down through the generations. The traditional forests in North Lombok are all within or on the boundaries of the KPHL RB. Through this local knowledge and these traditions, communities have protected and used forest resources, accommodating the various needs for forest conservation, household needs, economic benefits, and cultural and religious practices. In principle, much of the exploitation of forest resources was at a subsistence level during this time.

Traditionally, communities recognized two types of forest management systems: (1) pawang, or sacred forests, often associated with important springs or water sources, frequently surrounded by large, old growth trees, and protected from any active use and (2) gawah, or forests where more active use was allowed (e.g. collection of timber and non-timber products, hunting), but managed under the jurisdiction of a pemangku (priest or steward). The term gawah toak was used to describe a fully intact forest, while gawah tutupan was used for protected, but managed forests (Yudilastiantoro and Sulistyo 2008; Sukardi 2009).

Traditional communities in Lombok often recognized local regulatory agreements (awiq-awiq) that codified rules of access and management, and outlined these rules in terms of the community's relation to the natural and spiritual world and individuals' responsibilities to each other within the community. Some examples of awiq-awiq associated with forest management include: (1) sanctions against hunting certain animals or felling certain tree species without the permission of the pemangku (e.g. in the villages of Semokan and Sukadana). Offenses are paid for with fines, either monetary or by replacement of the wood or animals (Wadi 2011), and these fines are determined by the pemangku; (2) rules regarding the personal use of fire, hunting, grazing, immoral activity, pollution of the water source or any other activity that has a negative impact on the forest (e.g. in Bayan); and (3) rules that involve serious sanctions (including sacrifice of livestock) for breaking forest restrictions (e.g. in Bentek and Baru Murmas). In these communities, customary forests are still used only for ritual and religious practices (Sukardi 2009; Wadi 2011).

In communities with extant customary forests, focus group discussions validated the continued role of the pemangku (sometimes referred to as mangku), or forest steward, as the recognized local authority with responsibility for maintaining these traditions and the rules and sanctions outlined in the awiq-awiq. In North Lombok, the term Wet Tu Tlu is used to describe the traditional division of authority and control in Sasak society, and this term encompasses all social interactions, including religious affairs (with leadership by the local kyai), community-level governance (led by the pembekel) and customary law or adat (under the authority of the pemangku). With respect to forest management, the pemangku is known by several different names in different locations in North Lombok: Pemangku Lawangan for the traditional (Pawang) forest in Lawangan, Pemangku Perumbak Lauk for the forest in Montong Gedeng and Pemangku Perumbak Daya for the forest in Bangket Bayan. In several traditional forests, communities have appointed forest guards (or lang-lang) to assist the pawang in forest protection activities (Yudilastiantoro and Sulistyo 2008; Sukardi 2009; Wadi 2011). 


\section{Dutch colonial period}

At the end of the eighteenth century, economic and social development in Lombok was still largely focused on the central part of the island along the west-east corridor, and the upland forests surrounding Mount Rinjani were largely neglected. During this early period of Dutch colonialism, forests outside of Java were largely under the control of local chiefs or rajas and their traditional communities. In addition, many of the rajas in Lombok were preoccupied with local wars and conflicts, and gave little attention to exploiting natural resources. By the mid-nineteenth century, the Dutch government adopted more aggressive control measures, including the establishment of a national forest service (Jawatan Kehutanan, in 1865) to begin assuming greater authority over forest management in Indonesia. The Basic Agrarian Law of 1870 recognized the authority of local rajas and traditional communities over forest resources, but declared these forest areas under the jurisdiction of the Dutch Government. The Basic Agrarian Law established forest areas as state lands, with local rights (swapraja) granted under the supervision of Dutch colonial officials or pamong praja. Forest boundaries were delineated through negotiated agreements with local communities (Djajapertjunda 2002; Kraan 2009).

In the 1920s, the Dutch Government began mapping and measuring forest lands, particularly those deemed of high potential productivity, with the goal of increasing revenues from land taxes and from the harvesting of forest products (Kraan 2009). Formal gazetting of forest lands was completed during 1930-1950 (Djajapertjunda 2002). The result of this process was termed registered forest land (Register Tanah Kehutanan or RTK). The forests of Lombok were divided into 20 RTKs, with a total area of 162,437 ha. For the current KPHL RB, several documents show that forest boundaries were delineated on 9 September 1929 and included: (1) RTK 1 Rinjani, with a total area of 125,000 ha (boundaries formally approved 1941), ${ }^{3}$ within which 41,330 ha was designated as a wildlife preserve (suaka margasatwa). RTK 1 was subsequently divided into the Mount Rinjani National Park and the KPHL Rinjani Barat (in 2009); (2) RTK 2 Pandan Mas (boundaries delineated in 1936), and (3) RTK 6 Ranget, established in 1941 (KPHL Rinjani Barat 2013).

Unlike in Java, where the Dutch Government gained full control of forest areas and applied intensive management practices, forest management in the outer islands was still generally limited to functional designation and inventory. As noted above, these forests were largely under the control of local rajas and traditional communities, so much so that national regulations, such as the Bosreglement (1913), Bosordonatie (1927) and other laws and policies were adapted to suit local conditions. While the Dutch Government recognized customary adat rights, the establishment of forest management institutions and the emerging legal framework resulted in diminished authority of the swapraja. However, limited control over forest management in Lombok, as one of many islands outside of Java, was the result of a number of factors, primarily the challenges of transportation, access and communication, the lack of dedicated professional staff, and the continued strong role of local rajas and traditional communities (Djajapertjunda 2002; Kraan 2009).

During the period 1941-1945, when the Dutch were forced from Indonesia during the Japanese invasion, most forest management activities (planning, exploitation, conservation management), especially in the outer islands, were effectively discontinued.

\section{Early independence: 1945-1965}

Following Indonesia's independence in 1945, forest management activities outside Java were quite limited, given the priorities for establishing a national government and formulating domestic policies. The new government approved the national constitution, which, among other things, provided the legal foundation for natural resource management, including forest management; Article 33 Section 3 stated that "land, water and all natural resources are under the control of the state, and used for the broadest public welfare." This Article provided the basis for the development of a strategic plan for forest management during this period (Departemen Kehutanan RI 1986).

At this time, the government of NTB consisted of distinct regional councils in Lombok and Sumbawa. The government largely adopted the existing system 
of colonial administration, initially referring to subregional areas as districts (e.g. Bayan or Tanjung) and subsequently as kecamatan, which were later split into what are currently referred to as desa (villages) and dusun (hamlets) (Kraan 2002).

Consistent with this emerging government administration, forest management in Lombok through 1949 was administered under the western Forest Inspection, part of the National Forest Agency established by the Dutch in Jakarta (Departemen Kehutanan RI 1986).

Beginning in 1954, forest gazettement continued, with the surrender of certain government lands, or 'GG' (Gouvernement grond) within the forest estate under the Forest Agency (Jawatan Kehutanan), e.g. in Bayan district. In the 1960s, forest management in Lombok remained under the administration of the Forest Service for Eastern Indonesia, and the emphasis remained on the delineation of forest zones, based on reference maps from registered forest land identified during Dutch rule.

\section{Central control: 1965-1998}

This period marks the pivotal development of forest management in Indonesia. Basic forestry policies were established through Law Number 5, 1967, and these significantly shaped forest management practices, including policies related to traditional community access and use rights. During this period, forest management by the state largely emphasized central control over all aspects of forest management and administration.

Forest terminology was described in Article 2 Section 1 , which defined forest as non-private land under State control, with use rights and management under the national government, and no longer recognizing tribal, traditional or regional forest areas. Subsequently, regional authority over forest management rested with provincial governments (based on Article 12), delegitimizing the swapraja system established under colonial rule, and establishing the national government as the principal planning and management authority. This law also provided the foundation for forest enterprise development by outside entities, as defined in Article 14 Section 3: "permits for forest management may be granted to national, regional, and private enterprises." In addition, Law Number 1, 1967, regarding foreign investment (Indrarto et al. 2012), and Government
Regulation Number 21, 1970 regarding Forest Enterprises (Hak Pengusahaan Hutan or HPH) and Forest Harvest Rights (Hak Pemungutan Hasil Hutan, $\mathrm{HPHH}$ ), led to rapid private investment and a shift in forest management to private, third party entities, with permits issued by the national government. During this period, government policies and regulations were dominated by these HPHs and emphasized extensive timber harvesting.

As noted above, in Lombok, community involvement in forest management before the issuance of private permits, was limited to fulfilling basic livelihood needs and local cultural practices. The HPH and HTI permits approved in the early 1990s in NTB and in Lombok were essentially the first direct experience with the large-scale economic development model that was a signature of the Suharto era (Indrarto et al. 2012). During this period, the central government issued two concession permits in Lombok: (1) PT Tambora Buana Lestari (HTI - 5000 ha) and (2) PT Angkawijaya Raya Timber (HPH - 22,000 ha) (Dinas Kehutanan Provinsi NTB 1990a and 2000b).

As will be seen in the analysis below, these concessions represent a pivotal event in recent deforestation in the KPHL Rinjani Barat. Forest areas in Senaru and Bayan were clear-cut by PT TBL and PT ART, and although their permits were valid through 2010, operations were discontinued in 2000 after the companies were driven out by local communities. ${ }^{4}$

Government agencies responsible for forest management have changed with subsequent government reforms. Until 2000, forest management was under the jurisdiction of the Regional Office of the Ministry of Forestry, representing the central government in the NTB region, and the Provincial Forest Service (Level 1), representing local government (Statistik Kehutanan 2000). This structure reflects the emphasis on central government control in providing a range of permits related to the $\mathrm{HPHs}$ - for timber harvest, sale and distribution of forest products, and forestry industries, including those for non-timber forest products.

4 One of the areas that exemplifies this reaction was Mejet Forest, located within the PT ART concession. The clearing of this forest encouraged extensive encroachment into the area, including the illegal division and occupation of the forest by the community, which to this day is still unresolved (Huzaini 2002; Pramaria 2013; Mukarom 2013b; dan Sutikno 2013 personal communication). 
Delineation of forest boundaries continued to be based on registered forest land designations through 1981, but during this period of growing centralized control the national government approved Law Number 756/KPTS/UM/10/1982, which established the Consensus Forest Use Plan (Tata Guna Hutan Kesepakatan or TGHK). TGHK was designed as a formal agreement-seeking process between the national government and the provinces, with the intention of re-establishing boundaries determined during the Dutch era. In Lombok, 98\% of the forest boundaries were affirmed through the TGHK process.

During the new order era, active law enforcement restricted local access and use within designated forest areas. However, following the fall of Suharto in 1998, a combination of factors - weak law enforcement capacity, increasing population pressure, and the advent of migrants into the forest seeking access to agricultural land, and the legacy of animosity toward the concessions - emboldened communities to occupy the forest to open new farming areas.

As a response to this extensive illegal encroachment, and as a reflection of the move to regional autonomy, the government shifted its focus to encouraging greater local participation in forest management. This emerging policy orientation actually predated the fall of the new order, formulated in Ministerial Decree 622/ KPTS-II/1995, Guidance for Community Forestry (later revised as 677/Kpts-II/1998). In Lombok, the first experiments with community-based forestry projects (Hutan Kemasyarakatan or HKm), offering formal recognition of the community's role in forest management, were implemented in the villages of Santong and Sesaot.

These changes in government policies and programs coincided with the rapid emergence of civil society organizations, or nongovernmental organizations (NGOs), which promoted community-based and pro-poor development approaches. In Lombok, since the early 1990s the first NGOs (LP3ES and Balai Karya) played a significant role in empowerment and advocacy in rural communities. Initially, NGOs were largely constrained by project-based funding, with no particular sectoral focus, but in the early 1990 s they began to emphasize particular issues, such as migrant workers (Koslata), urban development, legal aid (LBH APIK), and community-based forest management (LP3ES) (Sarbani, 2013, personal communication).

\section{Transition period: 1998-2002}

The passage of Law Number 41, 1999 marked the end of the regulatory framework established under the Basic Forestry Law of 1967, providing the foundations for the determination of status and function of Indonesia's forests, and the system of forest stewardship and management. During this transition period, illegal logging, encroachment, and occupation reached its peak, due to the political instability, the government's inability to enforce basic laws, lack of clarity on sanctions for offenders and growing dependence on forest lands for agricultural expansion. These conditions catalyzed a range of new policies and programs designed to achieve sustainable and equitable forest management, increase community participation and foster a more balanced approach that considered ecology, economic development, and social and cultural benefits.

Nationally, 1999 marked the beginning of Indonesia's transition to regional autonomy; the passage of Law Number 22, 1999 (regarding regional governments) and Law Number 25, 1999 (related to regional financing) provided the legislative foundation for the move toward decentralized governance. These changes outlined the transition in decisionmaking over natural resource management to local governments. For the forestry sector, this meant that local governments gained jurisdiction over production and protected forests, while conservation forests remained under the authority of the national government. However, due to limited local government capacity and the general uncertainty during this transition period, these new policies were inconsistently implemented. This period also saw extensive transfer of forest lands previously under local control to outsiders with access to technology, knowledge and capital, given the growing awareness of the productive capacity of these lands and the ease of obtaining permits for timber harvesting on private lands (Ijin Pengusahaan Kayu di Tanah Milik or IPKTM).

\section{Regional autonomy: 2002 to present}

The current national political system, in which authority has been devolved to provincial and district-level control, has meant significant change 
for the forestry sector. Local government units have begun to focus on resolving forest management disputes by emphasizing social, cultural and economic development. However, the excitement of reform has in many ways enabled increased access to the forest due to management neglect. BAPPENAS (2010) has reported that among all the causes of deforestation and forest degradation, the most important is the lack of effective management at the local level. For this reason, recent government policies in the forestry sector have shifted toward accelerating and strengthening local forest management institutions as an important means of decentralizing forest management authority (Widiaryanto 2014). The KPHs are responsible for improving forest management for multiple benefits - timber, forest products and a range of ecosystem services. In general, forestry development under this new management paradigm devolves responsibility for forest stewardship to the Provincial and District Forest Service and forest management to the KPHs.

In addition to the formation of the KPHs, there have been some recent key changes in laws and policies that continue to redefine national forest management authority and affect the delineation of forest boundaries. As one example, a recent decision of the Constitutional Court reinforced the rights of traditional adat communities, even if located within national forest boundaries (www. mahkamahkonstitusi.go.id 2013). While the implications of this ruling remain uncertain, it is worth noting that within the KPHL RB there are at least 30 customary forests that would in principle be removed from the KPH management area and become the management responsibility of local communities (Yudilastiantoro 2008).

With the establishment of the KPH system, a continuing challenge will be to develop the KPHs into professionally functioning institutions. The $\mathrm{KPH}$ has authority to manage forest areas that are not yet under concession or permit agreements (HKm, HTR, HTI, HPH, HD, etc. - see below), and they have crucial responsibilities in the area of forest inventory, planning, project implementation, education, and law enforcement.

NTB is among the provinces that have been quick to adapt to these rapid changes in forest management and administration. The province was among the first to respond to the 1999 initiative to designate the KPHs, and by 2008 had proposed the establishment of 29 units. ${ }^{5}$ The recent 5 -year strategic planning process (2009-2013) reflects concerns for a more balanced approach to forest management, one that considers both forest conservation and the well-being of local communities. Specific initiatives identified in the strategic plans include: a logging moratorium, the "one man, one tree" reforestation program, promotion of native forest species (including non-timber forest products and support for native seed nurseries), support for a range of community-based forestry models $(\mathrm{HKm})$, community forest plantations (butan tanaman rakyat, HTR), industrial forest plantations (butan tanaman industri, HTI), and community forests (butan rakyat, HR), and village forests (butan desa, HD), development of payment for ecosystem services (PES) programs, and strong support for the KPH system, including human resource development (Dinas Kehutanan Provinsi NTB 2012).

However, although reports have generally been optimistic, in reality the underlying forest management challenges have not changed dramatically. Data from the KPHL Rinjani Barat shows that 24,000 families continue to occupy more than 18,000 ha of forest, with escalating conflicts in many forest margin communities (Mukarom 2013). Illegal logging continues, even though the scale has been reduced. Encroachment, occupation and the illegal transfer of forest lands all continue apace and have not been adequately addressed. From the economic standpoint, 20 years of forest utilization has done little to improve conditions in KPHL $\mathrm{RB}$ communities, which continue to reflect high poverty rates for the region, even though in a few locations (e.g. in the HKm project in Santong), forest productivity has significantly increased economic benefits to the community.

\section{Reducing Emissions from Deforestation and Forest Degradation (REDD+)}

As a commitment to REDD+ programs, and in the context of a cooperative agreement between Indonesia and Norway, the development of REDD+ institutions is a high priority for Indonesia, particularly in preparing for REDD+ implementation. In 2010, Indonesia formed a national REDD+ Working Group, which in 2013 became the REDD+ Management Agency, under

5 To date, the Governor and District Heads (bupatis) have only approved a total of $23 \mathrm{KPH}$ units. 
the direct supervision of the President. The development of the National REDD+ Action Plan was also begun in 2010. Despite almost four years of activity, the National REDD+ Management Agency has yet to identify a similar entity at the provincial level. Coordination of REDD+-related activities is currently the responsibility of the Provincial Forest Service (personal communication from Andi Pramaria, 2013).

REDD-related activities in NTB date from 1996-1997, in the form of the A/R CDM program sponsored by the Japan International Forestry Promotion and Cooperation Center (JIFPRO) in Sekaroh and Sambelia, Central Lombok. In 2009, the Korea International Cooperation Agency (KOICA) followed up in the Sekaroh area with a similar program (A/R CDM); in 2011, approval for a $306 \mathrm{ha} \mathrm{HKm}$ program was granted in this area (Siregar and Ridwan 2014).

At the same time, KOICA initiated a REDD Demonstration Area (DA) in the community of Aik Berik (Central Lombok) (Resusudarmo 2013). During the first 2 years (2009-2011) KOICA conducted a feasibility study, and began implementing program activities at the end of 2012.

The NTB provincial government instituted programs related to climate change and greenhouse gas emissions in 2010-2011 with the formation of a Working Group on Greenhouse Gases (Satuan Tugas Gas Rumah Kaca or Satgas GRK). The Working Group formulated an action plan that identified major sources of emissions, including those attributed to forest encroachment, illegal logging, and forest fires. In 2012 the NTB Provincial Forest Service, in cooperation with the Ministry of Forestry's Center for Climate Change Policy (PUSPIJAK) conducted several REDD-related outreach and research projects, with a specific focus on monitoring, reporting, and verification (MRV), and identified 33 sites for continuous carbon stock monitoring. MoF's Center for Standardization and Environment (PUSTANLING) focused on capacity building (training and workshop events) and the development of a professional network (personal communication from Andi Pramaria, 2013).

\section{Other actors' role in forest management}

While the focus of this analysis has been on the evolution of government policies and institutions, the pace of development in the forestry sector owes much to the role of other important actors, particularly local communities, NGOs and universities. Analysis of satellite imagery and focus group discussions from communities within the KPHL RB affirm the fact that community planting and reforestation efforts are largely responsible for the significant forest cover change noted in these areas, primarily due to the planting of a variety of agroforestry species. Concurrently, the emergence of local farmer working groups has been a critical aspect of successful community forestry projects. The new opportunities afforded to local communities to legally participate in forest management have encouraged communities to request additional approval for $\mathrm{HKm}$ projects, which now cover a total area of 14,836 ha in Lombok and Sumbawa, with four projects in the KPHL RB (Dishut NTB 2012). Recognition of the importance of local communities as a cornerstone of effective forest management has been reinforced by a number of recent regulations that seek to protect access and usufruct rights. Nevertheless, this emerging regulatory framework, particularly the process for approving $\mathrm{HKm}$ requests (which has been in place since 2007), continues to be slowed by an inefficient bureaucracy, a continuing source of frustration to local communities and community forestry advocates. Once again, the $\mathrm{KPH}$ is seen as a key opportunity for overcoming this bureaucratic inertia, since the KPHs can develop direct partnership agreements with local communities, circumventing the complex national approval process.

During this time, NGOs have also played an important role in the progress noted above, particularly in their work in building local leadership, education and capacity building, and in strengthening farmer working groups. The number of NGOs, particularly local NGOs, involved in the forestry sector, has increased significantly in recent years. Many of the key program innovations - such as PES, carbon accounting and conflict resolution efforts - have been initiated and led by NGOs. The NGOs have also been important partners in HKM programs in identifying project areas and facilitating the approval process, and they will continue to play an important intermediary role in building partnerships between communities and the KPHs. Among the NGOs that have provided consistent support for community-based forestry programs are: Konsepsi, YKSSI NTB, Transform, Samanta, Koslata, FFI (Flora \& Fauna International) and the WWF (World Wildlife Fund). 


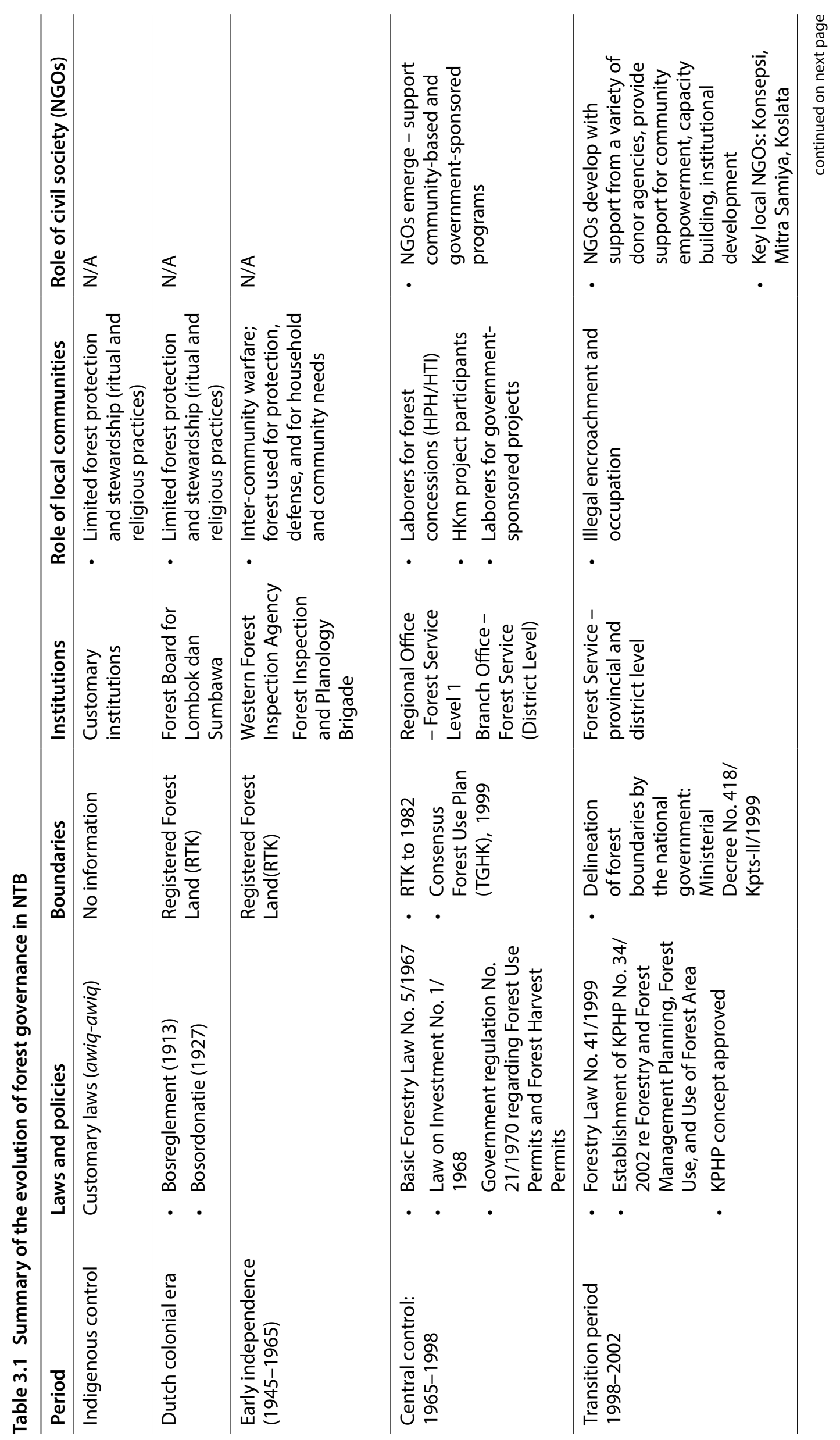




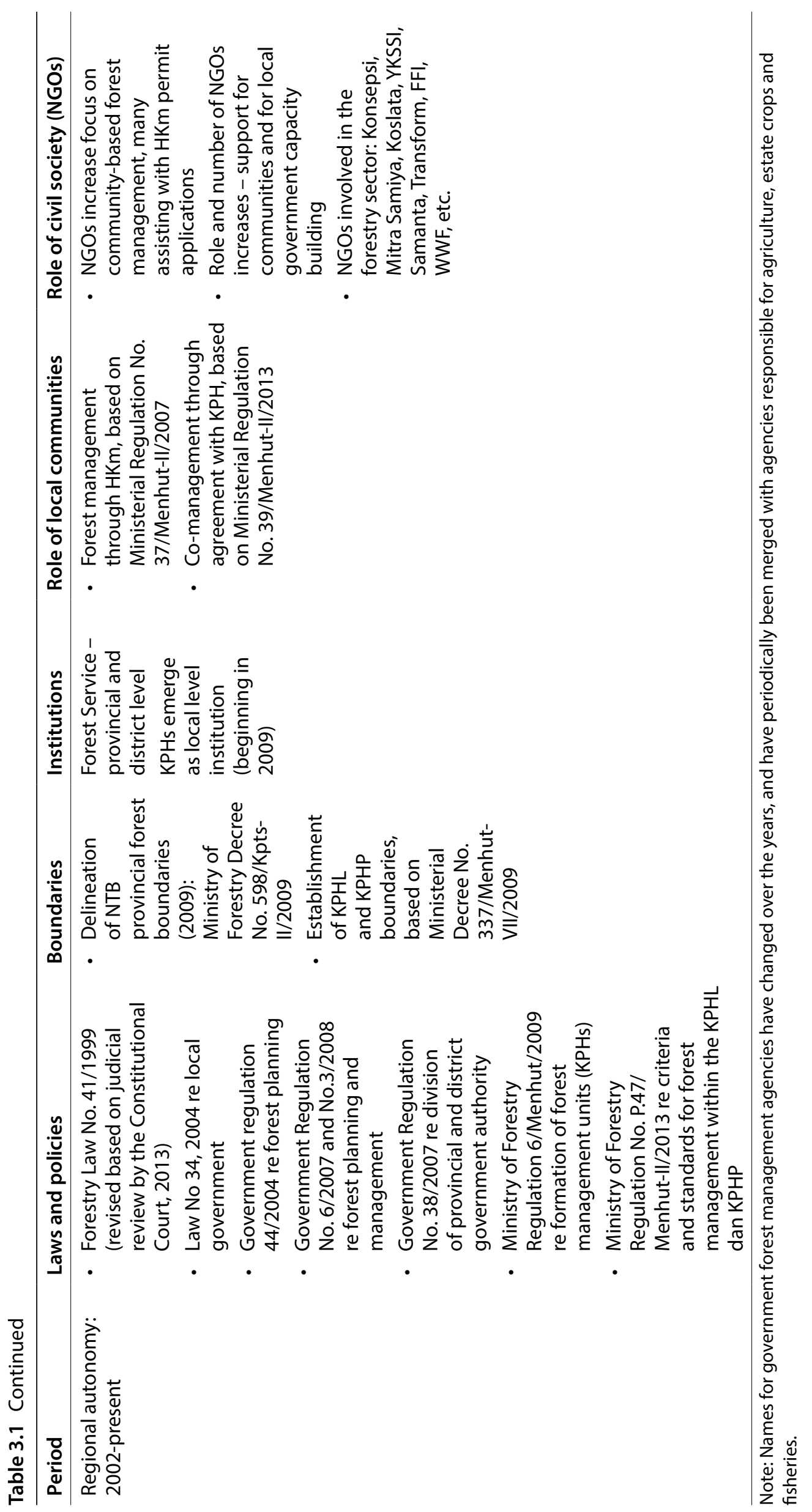




\section{Land-use change}

REDD+ financing is designed to provide incentives to protect forests for the value of their standing carbon. Thus, estimating verifiable carbon credits in a transparent way is essential for starting a conversation on any REDD+ proposal. For climate mitigation, simply reducing rates of deforestation and forest degradation is not enough; project proponents must demonstrate the amount of avoided emissions, based on the reference emission level (REL), which is the expected carbon emission rate from deforestation and forest degradation in the absence of interventions. The baseline for establishing RELs for REDD+ projects should include two components: land use and land-cover change and the associated carbon stock change. In this chapter, we describe the process for estimating the first component; Chapter 5 discusses methods for estimating carbon stock change.

Land use and land-use changes are the result of human uses of land and the interactions of global climate changes on the earth's surface. Land use and land cover play a major role in the carbon cycle by acting as a source or sink of carbon. Deforestation, afforestation and forest regrowth drive the release and sequestration of carbon, thereby affecting atmospheric $\mathrm{CO}_{2}$ concentration and the overall greenhouse effect (Asner et al. 2005; Gullison et al. 2007). Regular monitoring and assessment of land use and land-cover change are therefore critical for understanding how anthropogenic and natural changes (such as deforestation and forest degradation) at local, regional or global scales affect greenhouse gas concentrations in the atmosphere (Potapov et al. 2008).

Remotely sensed data has been widely used to classify land-cover and to provide estimates of land-uses. Remote sensing combined with ground measurements played a key role in determining the extent of forest cover loss with confidence from the 1990s (DeFries et al. 2006; GOFC-GOLD 2009). The strength of remote sensing is in its ability to provide spatially explicit information and repeated coverage of large areas, especially remote areas that are difficult to access otherwise (Lillesand et al. 1999). A variety of satellite data sources are used in classifying land use and establishing historical trends of forest changes, especially for deforestation and forest degradation. The selection of data sources depends upon the type of forest, coverage of the project area, existence of ground monitoring data, deforestation, the size of forest clearing and budget (Rosenqvist et al. 2003; DeFries et al. 2005; Gibbs et al. 2007).

Remote sensing image classification is a complex process that involves many steps, including the definition of a land cover classification system, collection of data sources, selection of a classification algorithm, extraction of thematic information, and accuracy assessment (Jensen 2005; $\mathrm{Lu}$ and Weng 2007). Technical progress in image classification has been achieved since the 1990s and a great deal of research has been conducted to classify land cover and monitor forest loss, especially for tropical forest vegetation (Tucker et al. 1985; Woodcock et al. 1994; Foody et al. 1996; Kartawinata et al. 2001; Tottrup 2004; Curran et al. 2004; Lu 2005; Li et al. 2011).

For REDD baseline setting, the most appropriate dataset is medium resolution satellite data, such as Landsat thematic mapper (TM) imagery. With global coverage, the regularly acquired largest historical archive and freely available space-based earth observations, Landsat imagery is preferred for monitoring tropical forests (Vieira et al. 2003; Salovaara et al. 2005; Kumar et al. 2010; Potapov et al. 2012; Das and Singh 2013; Zhuravleva et al. 2013). Several studies have reported deforestation and forest area changes in Indonesia using Landsat satellite data (Curran et al. 2004; Hansen et al. 2009, Miettinen and Liew 2010; Margono et al. 2012). These datasets play a key role in establishing historical deforestation rates in a particular region.

For this analysis in Lombok, we used available satellite Landsat TM images to analyze land use and land-cover changes, especially those related to deforestation and forest degradation during the past 20 years. This summary outlines our findings and their implications for developing a potential REDD+ program. 


\section{Materials and methods}

\section{Satellite images}

We used medium-scale Landsat multispectral scanner (MSS), thematic mapper (TM), and enhanced thematic mapper plus $($ ETM+) satellite images for the analysis. The study area, Lombok Island, is located at the position of Path 116/ Row 66 of the Landsat Worldwide Reference System (WRS). Landsat time-series data from 1990 to 2010 with 5-year intervals were selected for extracting information on land use and landcover changes. The images were downloaded from the US Geological Survey National Center for Earth Resources Observation and Science through the GLOVIS data portal (http://glovis.usgs.gov). Landsat datasets used for the study are listed in Table 4.1 and Figure 4.1.

In humid tropical forest environments such as Indonesia, cloud cover is a major problem in working with optical remotely sensed data (Asner 2001; Hansen et al. 2008; Margono et al. 2012). For regions with persistent cloud cover, obtaining timely data suitable for research objectives is frequently restricted. In this study, supplementary datasets were used to create improved time sequential image composites nominally centered for 1990, 2000, 2005 and 2010.

\section{Land-use classification system}

All land classes of interest in the survey area must be selected and defined carefully to successfully classify remotely sensed data into land-use and land-cover information. This requires the use of a classification scheme containing clear taxonomic definitions. Classes in the system should normally be mutually exclusive, exhaustive and hierarchical (Jensen 2005).

The IPCC Good Practice Guidance suggests six broad categories for representing land areas within a country: forest, cropland, grassland, wetland, settlements and other land (IPCC, 2003). Based on these land-use classifications, countries can estimate changes in carbon and other greenhouse gas stocks and emissions associated with different land uses.

We used the IPCC categories above and also further classified ten categories of land uses: forest (primary forest, secondary forest), shrubland, cropland (paddy field, dryland cultivation, estate croplands, such as coconut plantations), upland grassland, wetland, settlements and others, through direct field work and by referencing earlier reports (Jaya et al. 2011; Korindo 2012). Each class sufficiently represents different land uses on Lombok, reducing possible overlap and omissions as much as possible. The characteristics of each land-use category are described below:

Table 4.1 Satellite datasets used in the study

\begin{tabular}{|c|c|c|c|c|c|}
\hline \multirow{2}{*}{ No } & \multirow{2}{*}{ Satellite image } & \multirow{2}{*}{ Spatial resolution } & \multicolumn{2}{|c|}{ Acquisition date } & \multirow{2}{*}{ Remarks } \\
\hline & & & Primary data & Supplementary & \\
\hline 1 & Landsat-4 MSS & $80 \mathrm{~m}$ & 8 August 1987 & 12 March 1991 & \\
\hline 2 & Landsat-5 TM & $30 \mathrm{~m}$ & 26 May 1995 & & \\
\hline 3 & Landsat-7 ETM+ & $30 \mathrm{~m}$ & 19 August 2000 & 18 May 2001 & \\
\hline 4 & Landsat-7 ETM+ & $30 \mathrm{~m}$ & 13 May 2005 & 16 May 2006 & SLC-off, gap-filled \\
\hline 5 & Landsat-7 ETM+ & $30 \mathrm{~m}$ & 24 March 2010 & 15 October 2009 & SLC-off, gap-filled \\
\hline
\end{tabular}

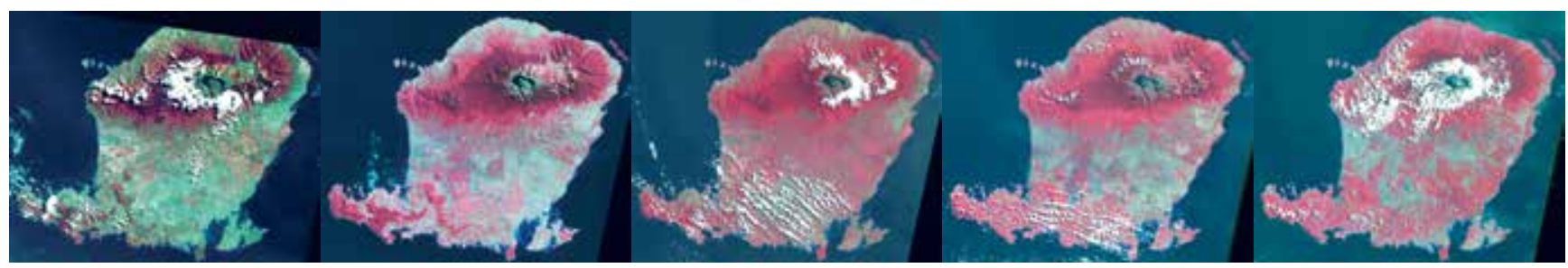

A) 1990

B) 1995

C) $\mathbf{2 0 0 0}$

D) $\mathbf{2 0 0 5}$

E) 2010

Figure 4.1 Landsat satellite images of Lombok from 1990 to 2010 at 5-year intervals 


\section{Forest}

Forest includes all land with woody vegetation, consistent with thresholds used to define forest land in a country (i.e. land area more than 0.5 ha with trees higher than $5 \mathrm{~m}$ and tree canopy of more than 10\%) (FAO 2010). Forest land in Lombok is further subdivided into primary forest and secondary forest. Primary forest in this study is defined as mature or intact forest, where standing stocks have almost reached stability. The forest is generally of native tree species; there are no clear indications of human activities and the ecological processes are not significantly disturbed. Secondary forest is regenerated forest that has been disturbed by human activities or natural disasters; it may include a natural forest with timber extraction, retaining artificial gaps in the tree canopy to 50-60\%.

\section{Shrubland}

Shrubland refers to land with woody vegetation where the dominant woody elements are shrubs, bushes and young generation trees, and generally less than $5 \mathrm{~m}$ in height (FAO 2001a). The latter appears usually after forest clear-cutting activities without crop cultivation.

\section{Cropland}

Cropland is arable and tillable land, including rice fields and dryland cultivation areas. Cropland includes land covered with temporary (or annual) crops, followed by harvest and a period of bare soil or fallow. Coconut plantations are considered a sub-category of cropland in Lombok since they have been established for estate crop production.

\section{Upland grassland}

Upland grasslands are areas with herbaceous cover, but without crop cultivation. Trees and shrubs can be present, but cover is less than $10 \%$. Upland grassland usually appears around the upper elevations of Mount Rinjani.

\section{Wetland}

Wetlands includes areas and lands that are covered or saturated by water for all or part of the year. These include reservoirs, rivers, lakes and streams, and these are classified as either natural or constructed.

\section{Settlement}

Settlement comprises all developed land, including areas of human habitation and transportation infrastructure.

\section{Other}

This class includes exposed soil, rock and all other unmanaged land areas that do not fall into any of the previous classes.

\section{Image classification and change detection}

For image classification, a supervised classification method was principally used. Supervised classification usually requires a priori knowledge about the region, where ground truth data has been collected for the training sites that are representative and homogeneous for each land-use class. A multidate land-use change detection was conducted using a 'binary change mask applied to date 2' algorithm which uses two-image datasets, i.e., Date 1 and Date 2 data (Jensen et al. 1993; Jensen 2005). We selected this method because it provides detailed 'from-to' change information in spite of the complexity of the analysis.

We used the 1995 image as a base image and classified beforehand using a supervised classification method. Change detection using a binary change mask was then applied to the 2000 image, identifying 'changed' areas and producing a classification map of 2000 with the changed information between 1995 and 2000. This process was subsequently applied to 2005, 2010 and again to 1990 (see Figure 4.2).

\section{Results and discussion}

\section{Land-use classification}

Land-use and land cover data from 1990 to 2010 are summarized in Table 4.2. As of 2010, cropland dominates the land cover of Lombok, comprising $61.4 \%$ of the total area. Forest is the second dominant land cover class, covering approximately 118,369 ha, or about $25.8 \%$ of the land. Shrubland, occupying $7.5 \%$ of the land area, appears around the transition zone between forested and non-forested lands, or along the edges of the Mount Rinjani crater. Because of their similar spectral reflectance signatures, it was difficult to differentiate shrubland from dryland agriculture on Landsat images. Landuse classification maps from 1990 to 2010 are shown in Figure 4.3.

Primary and secondary forests are relatively well distinguished in Landsat imagery. On the Landsat TM false color composite image, the tones of primary forests appear dark reddish brown compared to secondary forests, which usually show a redder and smoother texture than mature forests. Primary forests 


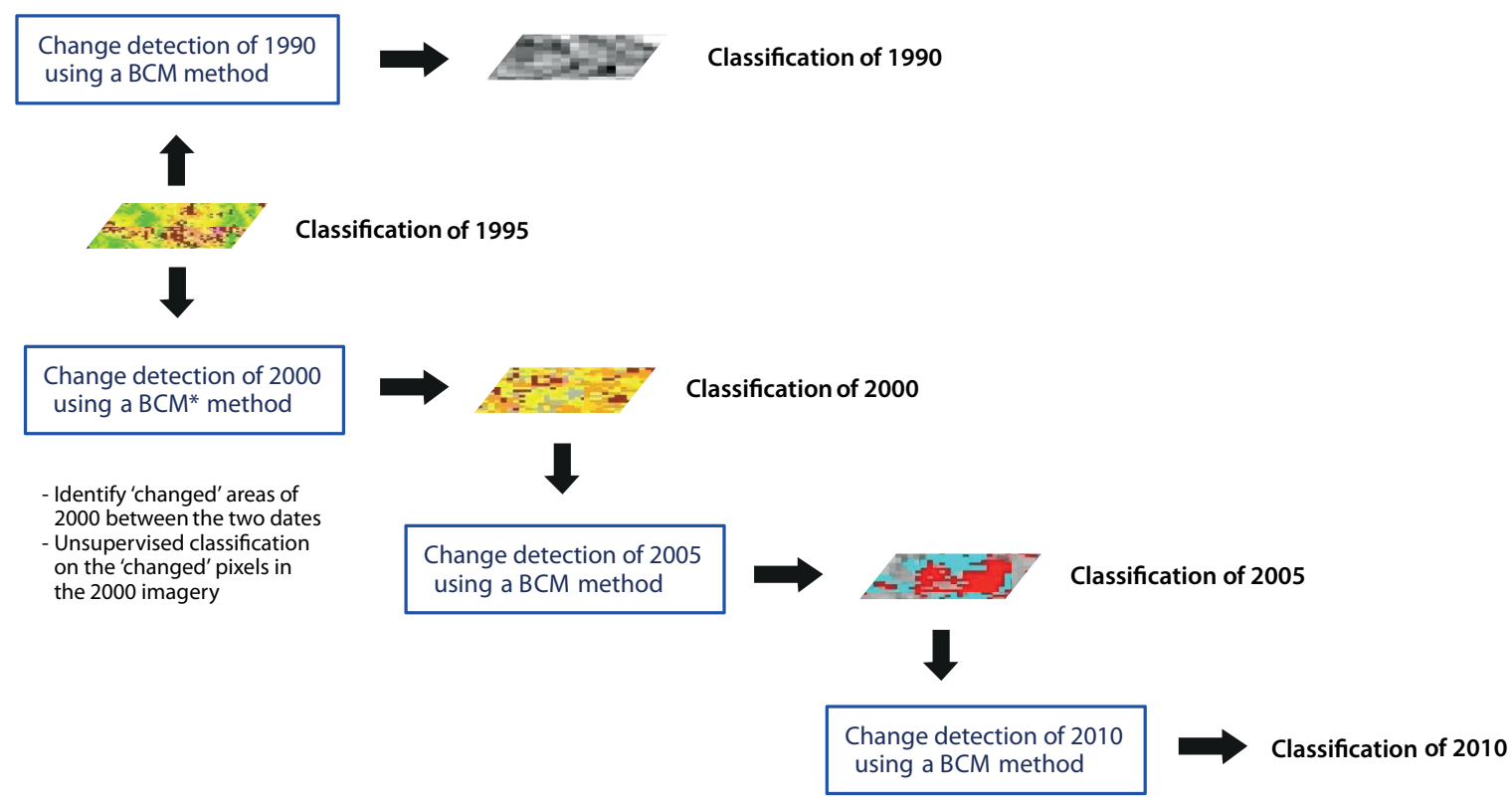

Figure 4.2 Diagram of multi-date image classification and change detection

* BCM: Binary Change Mark

Table 4.2 Land-use classification of Lombok, from 1990 to 2010 (ha)

\begin{tabular}{lrrrrr}
\hline Class name & \multicolumn{1}{c}{$\mathbf{1 9 9 0}$} & \multicolumn{1}{c}{$\mathbf{1 9 9 5}$} & \multicolumn{1}{c}{$\mathbf{2 0 0 0}$} & \multicolumn{1}{c}{$\mathbf{2 0 0 5}$} & \multicolumn{1}{c}{$\mathbf{2 0 1 0}$} \\
\hline Primary forest & $66,433.4$ & $54,880.7$ & $53,139.5$ & $51,114.4$ & $51,110.6$ \\
Secondary forest & $99,299.1$ & $105,064.2$ & $77,452.3$ & $69,752.1$ & $67,258.0$ \\
Shrubland & $14,119.2$ & $12,767.3$ & $33,626.5$ & $42,051.6$ & $34,418.6$ \\
Dryland agriculture & $154,337.2$ & $145,704.5$ & $171,472.2$ & $165,500.1$ & $175,844.4$ \\
Paddy field & $54,010.5$ & $62,834.2$ & $63,822.5$ & $66,286.6$ & $66,213.5$ \\
Estate crop & $52,957.7$ & $53,067.6$ & $36,975.5$ & $39,263.1$ & $39,119.3$ \\
Upland grassland & $4,382.9$ & $7,682.8$ & $6,314.9$ & $7,161.4$ & $7,158.0$ \\
Wetland & $3,439.7$ & $3,329.9$ & $3,328.9$ & $3,346.2$ & $3,346.6$ \\
Settlement & $3,073.2$ & $7,940.8$ & $7,384.9$ & $8,666.5$ & $8,663.4$ \\
Others & $6,154.0$ & $4,935.1$ & $4,689.8$ & $5,064.6$ & $5,074.1$ \\
Total & $\mathbf{4 5 8 , 2 0 7 . 0}$ & $\mathbf{4 5 8 , 2 0 7 . 0}$ & $\mathbf{4 5 8 , 2 0 7 . 0}$ & $\mathbf{4 5 8 , 2 0 6 . 5}$ & $\mathbf{4 5 8 , 2 0 6 . 5}$ \\
\hline
\end{tabular}

in Lombok are mainly distributed in the remote and hilly areas around Mount Rinjani, while secondary forests are found at low altitudes, near roads and settlements.

When attempting to identify agricultural cropland, the results may vary considerably depending on the date of image acquisition, because crop vegetation grows and is harvested according to seasonal and annual phenological cycles. Lombok is a tropical island with two seasons, a rainy season that begins in November and ceases in March, and a dry season that lasts from March to October. In areas with sufficient rainfall or irrigation, such as in western Lombok, rice is cultivated in paddy fields from December until the following July, and often intercropped with cassava, beans and vegetables. However, in other areas, plants that do not require much water (e.g. corn, peanuts and tobacco) are cultivated during the dry season. A location that could be classified as paddy fields or dryland agriculture in a satellite image will therefore depend 


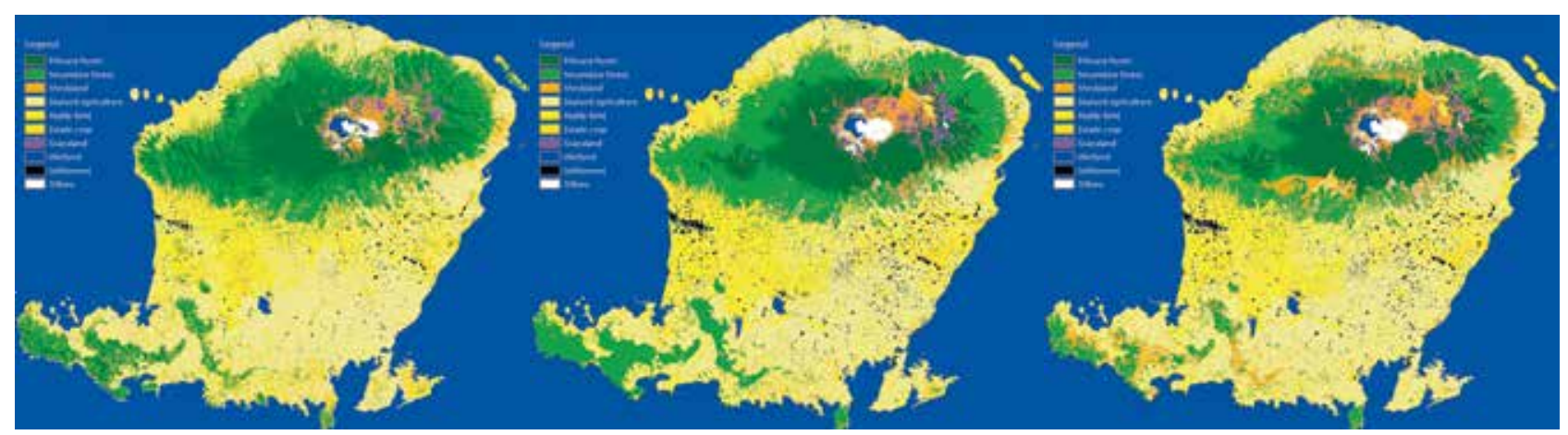

A) 1990

B) 1995

C) $\mathbf{2 0 0 0}$

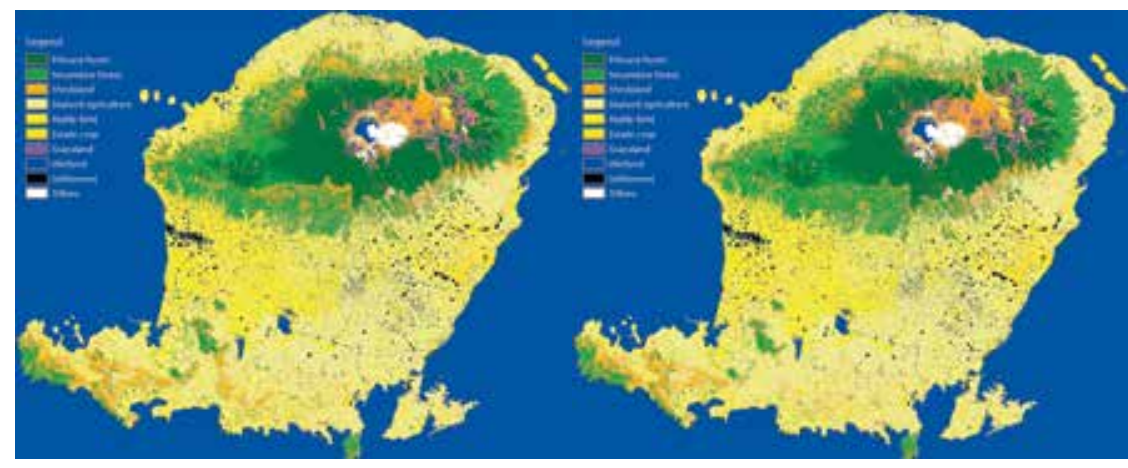

D) 2005

E) 2010

Figure 4.3 Land-use classification of Lombok from 1990 to 2010

on the date or season of observation. During the growing season, paddy fields exhibit a pink color in Landsat false color images, while dryland cultivation areas show light brown colors, often leading to confusion with shrubland. Therefore, comparing the area of paddy fields to dryland agriculture in Lombok is insignificant, although the total is somewhat indicative.

Coconut palm plantations constituted 39,119 ha or $8.5 \%$ of the total land area of Lombok. In tropical and subtropical regions, coconut is quite common, as it provides for many household necessities, including food, fiber, timber and fuel. Coconut is usually found from sea level to $150 \mathrm{~m}$, but grows up to $600 \mathrm{~m}$ in elevation near the equator (Chan and Elevitch 2006). In Indonesia, it is illegal to plant coconut within designated forest areas, so they are generally established on private lands, either as a monoculture or mixed with other tree crops. Coconut is an estate crop like oil palm and both are woody perennials with a more or less defined crown, consistent with the threshold for definition of forest. For this reason, they are sometimes included within the forest category (FAO 2001b; FAO
2007). In this study, however, we decided to place estate croplands, such as coconut plantations, as part of cropland, as they represent human-induced encroachment. From Landsat imagery, this class exhibits a light orange color, but may appear similar to secondary forest. In Lombok, most coconut trees are distributed along the coastal areas and often on the slopes of lowland hills.

Shrubland is a type of wooded land area covered with shrubs, and intermixed with sprouts, saplings, or brush vegetation. It often occurs after forest clear-cutting, and appears around the edges of the volcanic crater. Shrublands are also found in arid and semiarid regions of eastern Lombok, occasionally in forest transition areas. These areas are often mixed with croplands, forests or other land uses. Vegetation height is relatively short and cover is sparse, so shrubland shows as light red on the Landsat TM false color composite image.

Classifying shrubland as a distinct subclass is unique to this study and is based upon the local context of land-use changes. FAO guidelines generalize land cover to forest, wooded lands and other land uses in 
Table 4.3 Land-use and land-cover transition in Lombok, 1990 to 2010

\begin{tabular}{rlrrrrrrrr}
\hline & & \multicolumn{7}{c}{$\mathbf{2 0 1 0}$} \\
\cline { 2 - 9 } & Forest & Shrubland & Cropland & Grassland & Wetland & Settlement & Others & \multicolumn{1}{c}{ Total } \\
\hline \multirow{3}{*}{1990} & Forest & $113,291.6$ & $22,420.6$ & $25,749.0$ & $3,154.9$ & 21.7 & 112.2 & 982.5 & $165,732.5$ \\
& Shrubland & $1,054.0$ & $5,608.9$ & $5,992.5$ & 894.6 & 6.0 & 114.5 & 448.8 & $14,119.2$ \\
& Cropland & $3,370.9$ & $4,810.5$ & $245,739.9$ & 770.6 & 477.1 & $5,173.2$ & 963.2 & $261,305.5$ \\
& Grassland & 228.7 & $1,351.7$ & 413.6 & $2,302.7$ & 0.3 & 0.6 & 85.3 & $4,382.9$ \\
& Wetland & 13.6 & 4.4 & 405.9 & 0.2 & $2,437.4$ & 220.7 & 357.5 & $3,439.7$ \\
& Settlement & 1.0 & 1.2 & 414.3 & 0.2 & 7.9 & $2,627.0$ & 21.7 & $3,073.2$ \\
& Others & 408.8 & 221.4 & $2,462.1$ & 34.7 & 396.2 & 415.2 & $2,215.6$ & $6,154.0$ \\
\multirow{2}{*}{ Total } & & $\mathbf{1 1 8 , 3 6 8 . 6}$ & $\mathbf{3 4 , 4 1 8 . 6}$ & $\mathbf{2 8 1 , 1 7 7 . 2}$ & $\mathbf{7 , 1 5 8 . 0}$ & $\mathbf{3 , 3 4 6 . 6}$ & $\mathbf{8 , 6 6 3 . 4}$ & $\mathbf{5 , 0 7 4 . 6}$ & $\mathbf{4 5 8 , 2 0 7 . 0}$ \\
\hline
\end{tabular}

Table 4.4 Land-uses of KPHL Rinjani Barat from 1990 to 2010 (ha)

\begin{tabular}{lrrrrr}
\hline Class name & \multicolumn{1}{c}{$\mathbf{1 9 9 0}$} & \multicolumn{1}{c}{$\mathbf{1 9 9 5}$} & \multicolumn{1}{c}{$\mathbf{2 0 0 0}$} & \multicolumn{1}{c}{$\mathbf{2 0 0 5}$} & \multicolumn{1}{c}{$\mathbf{2 0 1 0}$} \\
\hline Primary forest & $22,839.3$ & $16,509.5$ & $16,439.8$ & $15,804.0$ & $15,772.5$ \\
Secondary forest & $15,969.3$ & $21,656.5$ & $17,803.1$ & $15,955.3$ & $15,905.6$ \\
Shrubland & 224.2 & 454.7 & $3,742.0$ & $6,266.9$ & $5,389.8$ \\
Dryland agriculture & 121.0 & 169.5 & 888.4 & 852.7 & $1,661.0$ \\
Paddy field & 94.4 & 113.9 & 105.3 & 104.4 & 102.0 \\
Estate crop & 212.6 & 76.7 & 43.3 & 41.2 & 40.0 \\
Grassland & 80.4 & 529.9 & 488.1 & 485.7 & 481.7 \\
Wetland & 5.8 & 0.0 & 0.0 & 0.0 & 0.0 \\
Settlement & 0.1 & 2.3 & 2.0 & 1.8 & 1.7 \\
Others & 52.7 & 86.7 & 87.8 & 87.7 & 85.8 \\
Total & $39,599.6$ & $39,599.6$ & $39,599.6$ & $39,599.6$ & $39,440.3$ \\
\hline
\end{tabular}

monitoring the world's forests through the Forest Resources Assessment Programme (FAO 2010). Here, shrubland is categorized as a subclass of other wooded land, which refers to "land not classified as forest", with a crown cover of $5-10 \%$ of trees able to reach a height of $5 \mathrm{~m}$ at maturity, or with a combined cover of shrubs, bushes and trees greater than 10\% (FAO 2001a). The definition of forest by the UNFCCC and FAO includes areas that are temporarily unstocked as a result of human interventions, such as harvesting or natural causes, and which are expected to regenerate or return to forest within several years. In this context, shrubland classified through image interpretation in this study may include certain areas that are 'temporarily unstocked' due to clear-cutting or overexploitation, i.e. they are assumed to be non-forests, but are expected to regenerate, and therefore may be included as forest in the future. In this study we inferred such unstocked land area and shrubland as forest degradation for the present time, since they suffer structural and functional changes that reduce biomass and the capacity of the forest to provide goods and services. However, there remained some difficulties in differentiating such future forests from genuine arid or alpine shrubland with Landsat satellite images.

For the accuracy assessment, an error matrix was created (Congalton 1991; Foody 2002) for the 384 reference points to compare the land-use classification results obtained by satellite data analysis with the reference or ground truth data. The overall assessment of accuracy was $75.3 \%$, and the kappa coefficient was $70.1 \%$ for the study. Major errors were due to the confusion between secondary forest and coconut plantations, and low separation between shrubland and dryland agriculture. 


\section{Land-use change}

Forest land in 1990 was estimated at 165,732 ha, or $36 \%$ of the total land area on Lombok (Table 4.3). Since then, forest land has decreased by 47,363 ha over the past 20 years. This means that $28.6 \%$ of forests (based on 1990 figures) have been converted to non-forest land use, and mostly to cropland and shrubland. Forest land decreased most significantly during the 5-year period from 1995 to 2000 . The forested areas in the southwestern parts of the island revealed much greater deforestation, while the central and northern regions around Mount Rinjani showed deforestation mostly along the forest edges, characterized by a pattern of frontier deforestation and forest degradation due to agricultural land expansion.

\section{KPHL Rinjani Barat}

Land use and land-use changes in the KPHL Rinjani Barat, are presented in Table 4.4. In 2010, primary forests and secondary forests comprised $80.3 \%$ of the total land area of this region, shrubland accounted for $13.7 \%$, and agricultural land $4.5 \%$, respectively. Forest cover in the area was more than $95 \%$ until 1995 , with persistent decreases since then, and with an increasing tendency for conversion to shrubland.
From 1995 to 2010 , forest area decreased by 432 ha annually, and from 1990, a total forest cover of 7,130 ha $(18.0 \%)$ has been deforested or degraded in some way. The pattern of forest cover decrease is both of a mosaic character and shows particular impacts along the forest boundary. Significant deforestation and conversion to agricultural land is particularly noted near the resort area of Senggigi.

Each province in Indonesia has its own history, and the drivers of forest cover change are very much influenced by a confluence of national and local factors. For example, forest fires played a major role in forest clearing in South Sumatra (Tacconi, 2003), while expansion of rubber plantations was the primary source of forest degradation in Jambi (Ketterings et al. 1999). In general, high rates of forest loss and fragmentation have been due to concession-based timber extraction, establishment of oil palm and pulp plantations, and weak governance institutions (Holmes 2002; Curran et al. 2004). In Lombok, patterns of deforestation and forest degradation are affected by unique local drivers, including demographic changes, development, and other socioeconomic conditions. The analysis of these factors in the KPHL Rinjani Barat, and their impacts on forest health are reviewed and analyzed in Chapter 6. 


\section{Estimation of carbon stock and carbon stock change}

Forest carbon estimation and monitoring for REDD+ projects must comply with international agreements and standards, in order to maintain consistency and precision in these measurements. UNFCCC requires that countries follow IPCC guidelines regarding land use and forest carbon stock changes in GHG emissions (IPCC, 2003, 2006), and recommends the use of remote sensing and ground-based forest carbon inventory approaches in combination to estimate forest carbon stock for REDD+ (UNFCCC 2009). The IPCC (2003, 2006) suggests that carbon stock changes should be calculated and reported for the main carbon pools in the forest ecosystem, i.e. living biomass of trees, dead mass of litter, woody debris, and soil organic matter.

However, it is important to adopt an appropriate research design and methodology to fit each country's unique circumstances and needs, rather than applying a single uniform standard. In this study, we conducted surveys of the carbon stock for primary forest, secondary forest and shrubland. We estimated forest carbon stock for five carbon pools: aboveground biomass (big trees, smaller trees, saplings, understory vegetation), belowground biomass (roots), dead wood (standing and fallen deadwood, stumps), litter and soils. We applied these figures in establishing a reference emission level (REL) and quantifying the amount of avoided emissions in the KPHL RB.

\section{Methodology and data collection}

\section{Sample size and arrangement}

We used stratified sampling methods to estimate carbon stock in the KPHL RB, relying on land-use classifications (outlined in Chapter 4) for forest area estimation and stratification, and carried out ground surveys to determine forest carbon stock by stratum. The number of sample plots $(n)$ for estimating carbon stock was determined with the following equation (1): (Pearson et al. 2007; Hirata et al. 2012)

$\mathrm{n} \geq(t c / e)^{2}$

where $e$ is the allowable error rate, $c$ is the expected coefficient of variation, and $t$ is the value for a
95\% confidence interval at the specified degree of freedom. The value of $t$ is constant and usually substituted by 2 . We applied an error rate of $12 \%$, since previous experience suggests that the permissible error rate in a tropical forest is approximately 10\% (Hirata et al. 2012), and no more than 20\% (MoF 2011). The coefficient of variation (40\%) was obtained by referencing other survey results from nearby forests in Lombok (KORINDO 2011). Based on the above equation, we identified a total of 45 sample plots. Using the Neyman optimum allocation method (Bartlett et al. 2001), we divided the sample plots by forest stratum, i.e. 26 sample plots for primary forest, 15 plots for secondary forest, and 4 plots for shrubland, respectively, and distributed the sample plots randomly within the stratum (Figure 5.1).

To estimate forest carbon stock by carbon pool in the KPHL Rinjani Barat, the shape of the sample plot was designed to be rectangular (0.1 ha.), with nested compartments of different sizes (Figure 5.2). Trees $(\mathrm{DBH} \geq 20 \mathrm{~cm})$ were inventoried within the base plot (Plot $\mathrm{A})$, and deadwood, trees of small diameter $(10 \mathrm{~cm}<\mathrm{DBH} \leq 20 \mathrm{~cm})$, and saplings $(2 \mathrm{~cm}<\mathrm{DBH} \leq 10 \mathrm{~cm}$, height $\geq 1.5 \mathrm{~m})$ were surveyed within subplots $\mathrm{B}, \mathrm{C}$ and $\mathrm{D}$, respectively. Understory vegetation, litter and soil were surveyed in subplot E. This survey system supports two replication measurements for small diameter trees, undergrowth vegetation and litter, and three replications for soil carbon.

\section{Field measurement and analysis}

We estimated forest carbon stock in the KPHL RB based on field measurements for five carbon pools: aboveground biomass, belowground biomass, deadwood, litter and soil. Direct measurement of carbon stock was conducted for all of the carbon pools except belowground biomass, for which we indirectly measured the amount of carbon stock using an estimation model. Staff of the Korea Forest Research Institute and survey crews of the KPHL RB conducted field surveys from June to August 2013.

Aboveground biomass is comprised of standing trees and undergrowth vegetation. All tree species 


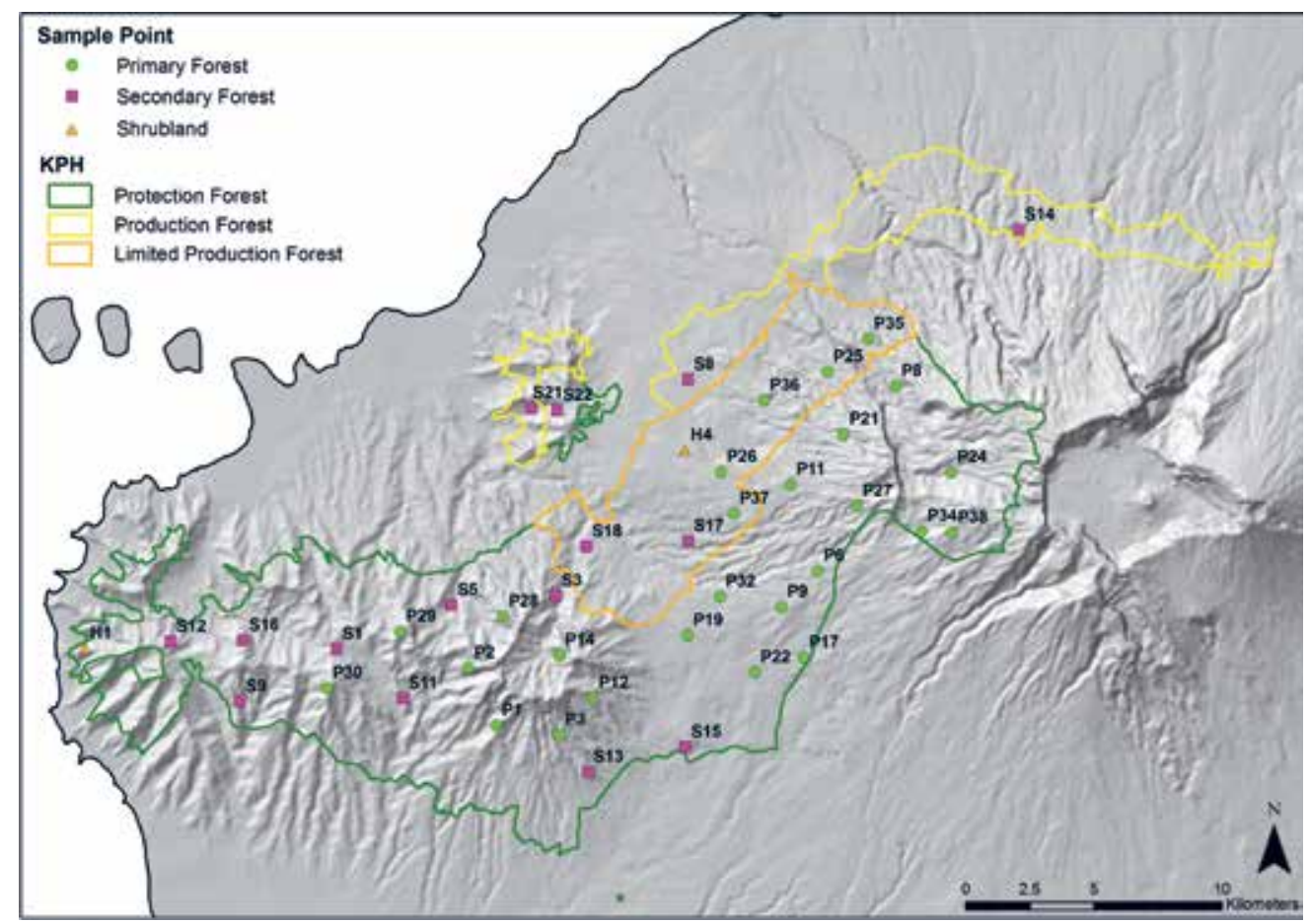

Figure 5.1 Location of the sample plots

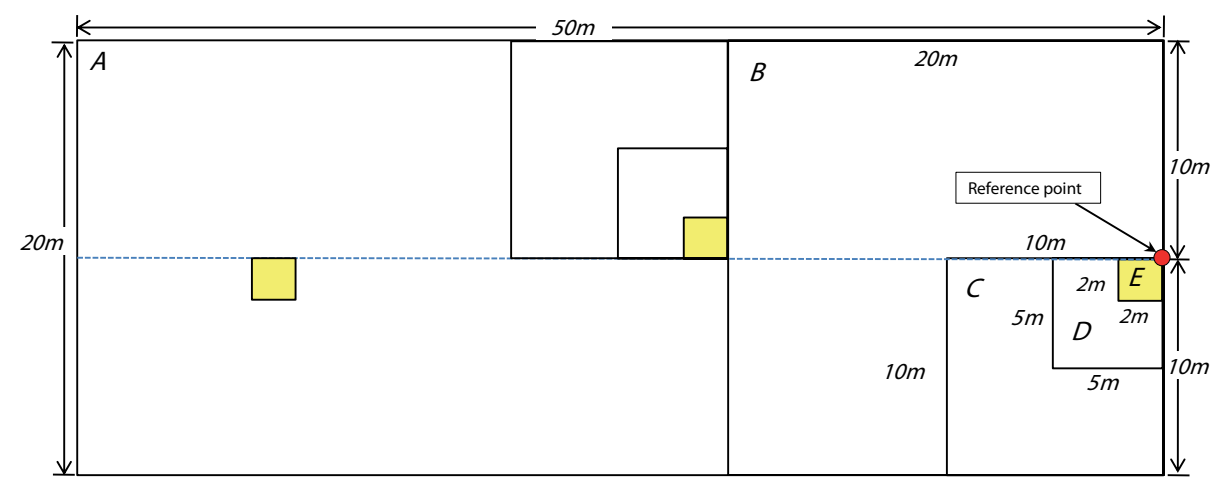

Figure 5.2 Sample plot design

were measured in plot $A$ and within subplots $C$ and $\mathrm{D}$, including identified saplings and their diameter at breast height, or DBH $(1.3 \mathrm{~m})$. Tree volume and biomass were then calculated using the relevant allometric equation (Basuki et al. 2009; Ministry of Forestry 2012).

\section{$\mathrm{V}=0.000051464 \mathrm{D}^{2.5874}$}

$\operatorname{LnAGB}=-1.201+2.196 \ln \mathrm{D}$

Understory vegetation was obtained by the destructive harvesting method, which involves cutting and harvesting all aboveground herbaceous material within the relevant subplot. After measuring total fresh weight, samples of approximately $300 \mathrm{~g}$ were taken, weighed, and ovendried in a laboratory. Total undergrowth biomass was calculated based on the dry weight/fresh weight ratio. Litter was gathered within subplot $\mathrm{E}$, and litter biomass calculated using the method described for understory vegetation.

Deadwood, both standing and on the ground, includes all nonliving stems and branches longer than $1 \mathrm{~m}$, and $10 \mathrm{~cm}$ or larger in diameter. Deadwood was subdivided into standing deadwood, deadwood lying on the ground and stump, by type. For any deadwood within 
subplot B, wood volume was measured and decay class examined to the level of intactness for biomass estimation. Total organic matter of the deadwood was derived by multiplying wood volume by wood density.

For standing deadwood, the biomass was estimated with the same allometric equations used for trees. In this case, the estimated biomass is further adjusted with a correction factor of 0.9 (A), 0.8 (B) and $0.7(\mathrm{C})$, respectively, according to the decay class, defined as: A: dead trees without leaves, B: dead trees without leaves and twigs, and C: dead trees without leaves, branches and twigs (MoF 2011). Belowground biomass (roots) was estimated based on the root/shoot ratio developed and generally used in tropical countries, as indicated by a basic default of 0.27 (IPCC 2006).

\section{Calculation of carbon}

Carbon content in trees, undergrowth vegetation and dead organic matter (litter and deadwood) was calculated from the biomass, using equation (4), its basic concept is consistent with relative IPCC equations (IPCC 2003, 2006):

$C_{b}=$ Biomass $\times C F$

where $C_{b}$ is the carbon content from biomass, Biomass is the total biomass of each pool, and $C F$ (carbon fraction) is the percentage value of content, amounting to 0.47 in Indonesia. Soil carbon was analyzed in the laboratory using the Wakley and Black method (SSSA 1994), with soil samples collected during field surveys. Carbon stock for each the five carbon pools is then obtained for each sample plot and converted to an amount per hectare. The total carbon stock in one stratum was calculated by multiplying the mean value of carbon content per hectare by the area of the stratum, obtained through analysis of satellite images.

\section{Results and implications}

\section{Forest survey}

\section{Overstory and understory vegetation}

This area is a naturally regenerated deciduous forest (primary and secondary forest) that is dominated by Eugenia polyantha and Callophylum inophyllum; the shrubland is dominated by Mangifera foerida and Duabanga mollucana. The average $\mathrm{DBH}$ and tree height $(\mathrm{H})$ were $33.4 \mathrm{~cm}$ and $16.0 \mathrm{~m}$ (Table 5.1). The number of trees per hectare for primary forest was 1094 , secondary forest 1059 and shrubland 205, respectively. The volume stock was $137.1 \mathrm{~m}^{3} /$ ha of primary forest, $130.3 \mathrm{~m}^{3}$ of secondary forest and $23.8 \mathrm{~m}^{3} / \mathrm{ha}$ of shrub land. There was no significant difference between the volume calculated for primary forest and that obtained for secondary forest, although our figures are somewhat higher than the average $79 \mathrm{~m}^{3}$ in Indonesia (IPCC 2003). In the previous survey, the protected forest showed volume stock at $92.0 \mathrm{~m}^{3} /$ ha (Ministry of Forestry 2010).

On the other hand, the most common understory woody vegetation (sapling) is Eugenia polyantha in primary forest, Schoutenia ovate in secondary forest and Artocarpus elasticus in shrubland. The abundance and frequency of understory species differs depending on land-use type; more understory species are found in the forest area than in shrubland, and the frequency of saplings in primary forests is almost twice that in secondary forest. In general, light and soil conditions are significant influences. The proportion of understory biomass (woody plus herbaceous) to aboveground biomass (overstory plus understory) ranges from $1.2 \%$ to $6.3 \%$, which

Table 5.1. DBH and height of trees by forest type

\begin{tabular}{lcccccc}
\hline Land-use type & $\begin{array}{c}\text { Area } \\
(\mathbf{h a})\end{array}$ & $\begin{array}{c}\text { DBH } \\
(\mathbf{c m})\end{array}$ & $\begin{array}{c}\text { Height } \\
(\mathbf{m})\end{array}$ & $\begin{array}{c}\text { Stand density } \\
(\text { trees/ha) }\end{array}$ & $\begin{array}{c}\text { Volume } \\
\left(\mathbf{m}^{3} / \mathbf{h a}\right)\end{array}$ & Dominant species \\
\hline Primary forest & $15,772.5$ & 33.9 & 17.1 & 1,094 & 137.1 & $\begin{array}{l}\text { Eugenia polyantha } \\
(18.7 \%)\end{array}$ \\
Secondary forest & $15,905.6$ & $\begin{array}{c}37.1 \\
( \pm 6.24)\end{array}$ & $\begin{array}{c}16.4 \\
( \pm 3.66)\end{array}$ & 1,059 & 130.3 & $\begin{array}{l}\text { Callophylum inophyllum } \\
(11.0 \%)\end{array}$ \\
Shrubland & $5,389.8$ & $\begin{array}{c}15.9 \\
( \pm 5.94)\end{array}$ & $\begin{array}{c}15.6 \\
( \pm 4.60)\end{array}$ & 205 & 23.8 & $\begin{array}{l}\text { Mangiferafoetida } \\
(36.4 \%)\end{array}$ \\
\hline
\end{tabular}


Table 5.2 Soil characteristics by forest type and soil depth

\begin{tabular}{lcccc}
\hline Forest type & $\begin{array}{c}\text { Soil depth } \\
\mathbf{c m}\end{array}$ & $\begin{array}{c}\text { Bulk density } \\
\mathbf{g} / \mathbf{c m}^{3}\end{array}$ & $\begin{array}{c}\text { Coarse fragment } \\
\%\end{array}$ & $\begin{array}{c}\text { Carbon concentration } \\
\%\end{array}$ \\
\hline Primary & Total & $0.57 \mathrm{bc}$ & $0.52 \mathrm{a}$ & $5.29 \mathrm{a}$ \\
forest & $0-10$ & 0.58 & 0.53 & 5.52 \\
& $10-20$ & 0.55 & 0.53 & 5.07 \\
& $20-30$ & 0.57 & 0.51 & 5.28 \\
\hline Secondary & Total & $0.68 \mathrm{ab}$ & $0.48 \mathrm{a}$ & $3.33 \mathrm{~b}$ \\
forest & $0-10$ & 0.69 & 0.46 & 3.58 \\
& $10-20$ & 0.67 & 0.49 & 3.47 \\
& $20-30$ & 0.67 & 0.48 & 2.95 \\
\hline Shrubland & Total & $0.66 \mathrm{ab}$ & $0.54 \mathrm{a}$ & $3.09 \mathrm{~b}$ \\
& $0-10$ & 0.66 & 0.45 & 2.70 \\
& $10-20$ & 0.62 & 0.64 & 3.50 \\
& $20-30$ & 0.69 & 0.53 & 3.50 \\
\hline
\end{tabular}

Note: Mean with different letters within columns are statistically different at $p<0.05$.

is negatively correlated with total aboveground biomass. Son et al. (2004) explained that light interception by overstory vegetation seems to influence production of understory vegetation.

\section{Soil}

Soil characteristics are shown in Table 5.2. Average bulk density and carbon concentration vary significantly among forest types based on differences in forest history and/or management. Although there were no significant differences among soil depths, carbon concentration tended to be higher in the upper layer $(0-10 \mathrm{~cm})$ than in deeper depths $(10-20 \mathrm{~cm}, 20-30 \mathrm{~cm})$ for primary and secondary forest. In the case of shrubland, however, carbon concentration was lowest in the upper soil layer and increased with soil depth, influenced by reduced litter content and increased soil hardness due to human disturbances on the surface.

\section{Forest carbon stock}

Calculation of forest carbon stock for each carbon pool and forest type is presented in Table 5.3. The total carbon stock (tC/ha) is $206.68 \mathrm{tC} / \mathrm{ha}$ for primary forest, $181.1 \mathrm{tC} /$ ha for secondary forest and $75.3 \mathrm{tC} / \mathrm{ha}$ for shrubland. The average carbon stock for aboveground primary and secondary forest is $103.8 \mathrm{tC} / \mathrm{ha}$. The average carbon stock in the aboveground measurements for the three land-use types is seen as the highest, with $78.0 \mathrm{tC} / \mathrm{ha}(47.5$ $\%)$. Carbon stock for soils followed, with a mean of $34.7 \mathrm{tC} / \mathrm{ha}(24.0 \%)$. The carbon stock for soil and aboveground comprises $71.5 \%$ of the total.

The results of previous studies estimating aboveground carbon stock for West and Central Lombok are summarized in Table 5.4. Carbon stock (tC/ha) ranges from $98.0 \mathrm{tC} /$ ha for tropical dry forest in West Lombok to $334.5 \mathrm{tC} /$ ha for Central Lombok $(<1500 \mathrm{~m})$. Except for the high elevation area in Central Lombok (334.5 tC/ha), the values are similar to the results for primary and secondary forests in this study. These values are similar to those reported in other studies, which ranged from 78 to $169 \mathrm{tC} / \mathrm{ha}$ in tropical regions (IPCC 2003; Gibbs and Brown 2007).

\section{Forest carbon stock change}

Based on land-use changes classified using Landsat images during the past 20 years (Table 4.4), figures for total forest carbon stock of KPHL Rinjani Barat are presented in Table 5.5.

Carbon stock decreased dramatically from 1990 to 1995 (from 4,729,236 tC to 3,410,636 tC). Due to the decrease in the total area of primary forest, carbon stock in these forests showed a decrease of $1.56 \%$ from 1990 to 1995 , using 2010 as a standard. In contrast, the total area of secondary forest increased during this time, resulting in an increase in forest carbon stock from 2,891,347 tC to $3,921,216 \mathrm{tC}$. Note that the annual change in shrubland increased dramatically during this time 
(115.2\%). The soil carbon stock declined following conversion from native forest to plantation $(-13 \%)$, native forest to agricultural land $(-42 \%)$, and pasture to cropland (-59\%) (Guo et al. 2002). The total carbon stock decreased at a rate of $-0.72 \%$ annually, compared to the carbon stock of 2010.

Table 5.3 Carbon stock by land use type (tC/ha)

\begin{tabular}{|c|c|c|c|c|c|c|c|c|}
\hline \multirow{3}{*}{$\begin{array}{r}\text { Carbon } \\
\text { pool } \\
\text { Forest } \\
\text { Type }\end{array}$} & \multirow{3}{*}{ Total } & \multicolumn{4}{|c|}{ Living vegetation } & \multirow{3}{*}{$\begin{array}{l}\text { Dead } \\
\text { wood }\end{array}$} & \multirow{3}{*}{ Litter } & \multirow{3}{*}{ Soils } \\
\hline & & \multicolumn{3}{|c|}{ Above-ground } & \multirow{2}{*}{$\begin{array}{l}\text { Below } \\
\text { ground }\end{array}$} & & & \\
\hline & & Sub-total & Tree & Undergrowth & & & & \\
\hline Primary forest & $\begin{array}{c}206.6 \\
( \pm 76.66)\end{array}$ & 109.9 & $\begin{array}{c}108.6 \\
( \pm 59.89)\end{array}$ & $\begin{array}{c}1.3 \\
( \pm 1.15)\end{array}$ & $\begin{array}{c}29.7 \\
( \pm 16.12)\end{array}$ & $\begin{array}{c}18.3 \\
( \pm 26.05)\end{array}$ & $\begin{array}{c}1.7 \\
( \pm 1.25)\end{array}$ & $\begin{array}{c}47.0 \\
( \pm 17.52)\end{array}$ \\
\hline $\begin{array}{l}\text { Secondary } \\
\text { forest }\end{array}$ & $\begin{array}{c}181.1 \\
( \pm 120.88)\end{array}$ & 97.8 & $\begin{array}{c}96.2 \\
( \pm 85.74)\end{array}$ & $\begin{array}{c}1.6 \\
( \pm 0.99)\end{array}$ & $\begin{array}{c}26.4 \\
( \pm 23.03)\end{array}$ & $\begin{array}{c}21.4 \\
( \pm 31.73)\end{array}$ & $\begin{array}{c}1.8 \\
( \pm 0.84)\end{array}$ & $\begin{array}{c}33.7 \\
( \pm 13.08)\end{array}$ \\
\hline Shrub land & $\begin{array}{c}75.3 \\
( \pm 6.74)\end{array}$ & 26.5 & $\begin{array}{c}24.8 \\
( \pm 2.30)\end{array}$ & $\begin{array}{c}1.7 \\
( \pm 0.98)\end{array}$ & $\begin{array}{c}7.2 \\
( \pm 0.89)\end{array}$ & $\begin{array}{c}16.7 \\
( \pm 6.76)\end{array}$ & $\begin{array}{c}1.6 \\
( \pm 0.43)\end{array}$ & $\begin{array}{l}23.4 \\
( \pm 3.72)\end{array}$ \\
\hline
\end{tabular}

Table 5.4 Carbon stock (tC/ha) in other studies

\begin{tabular}{|c|c|c|c|c|c|}
\hline Location & Elevation & Forest type & Pool & Carbon stock (tC/ha) & Reference \\
\hline \multirow{2}{*}{$\begin{array}{l}\text { West Lombok, } \\
\text { Indonesia }\end{array}$} & \multirow[t]{2}{*}{-} & & \multirow{4}{*}{$\begin{array}{l}\text { Above } \\
\text { ground } \\
\text { biomass }\end{array}$} & $\begin{array}{c}98.0 \\
(84.3-169.6)\end{array}$ & Takwim 2011 \\
\hline & & & & 125.7 & FORDA 2012 \\
\hline \multirow{2}{*}{$\begin{array}{l}\text { Central Lombok, } \\
\text { Indonesia }\end{array}$} & $<1500 \mathrm{~m}$ & \multirow{2}{*}{ Natural forest } & & 166.8 & \multirow{2}{*}{ KORINDO 2011} \\
\hline & $>1500 \mathrm{~m}$ & & & 334.5 & \\
\hline
\end{tabular}

Table 5.5 Carbon stock (tC/ha) changes by forest types (1990-2010)

\begin{tabular}{lrrrrr}
\hline Forest type & \multicolumn{1}{c}{1990} & \multicolumn{1}{c}{1995} & \multicolumn{1}{c}{$\mathbf{2 0 0 0}$} & \multicolumn{1}{c}{$\mathbf{2 0 0 5}$} & \multicolumn{1}{c}{$\mathbf{2 0 1 0}$} \\
\hline Primary forest & $4,729,236$ & $3,410,636$ & $3,396,175$ & $3,264,790$ & $3,258,386$ \\
Secondary forest & $2,891,347$ & $3,921,216$ & $3,223,411$ & $2,888,812$ & $2,879,940$ \\
Shrubland & 16,865 & 34,257 & 281,735 & 471,842 & 405,738 \\
Total & $\mathbf{7 , 6 3 7 , 4 4 8}$ & $\mathbf{7 , 3 6 6 , 1 0 9}$ & $\mathbf{6 , 9 0 1 , 3 2 2}$ & $\mathbf{6 , 6 2 5 , 4 4 5}$ & $\mathbf{6 , 5 4 4 , 0 6 5}$ \\
\hline
\end{tabular}




\section{Understanding drivers of deforestation and forest degradation}

As outlined in Chapters 4 and 5, we analyzed landuse and forest carbon stock changes to identify where and when forest areas in the KPHL RB became deforested. Significant deforestation (and decreasing forest carbon stocks) occurred between 1995 and 2000, but the rate of deforestation has generally decreased since 2000. The deforestation has been spatially identified as primarily along the frontier, or forest margins (see Figure 4.4). In this chapter, we describe the social and economic factors behind this observed deforestation in forest margin communities. Understanding the dynamics between socioeconomic factors and forest cover change is essential for projecting future trends and developing potential intervention strategies to reduce deforestation and forest degradation (Lambin et al. 2001).

\section{Methods}

Lack of proper documentation, limited reliability of demographic data and low literacy rates are common challenges of socioeconomic research in developing countries, and these were certainly important considerations for designing our research methodology. We relied on multiple methods for data collection and analysis, including review of available secondary data, as well as direct, community-based survey methods, such as participatory rural appraisal (Chambers 1994; Pretty 1995). The use of these multiple methods helped validate the varied and sometimes inconsistent secondary data obtained from the KPHL RB, and from village, subdistrict, district, and provincial government sources.

Within the KPHL RB, we conducted villagelevel research in the districts of West Lombok (including the four subdistricts Narmada, Lingsar, Gunungsari and Batu Layar) and North Lombok (including the five subdistricts: Tanjung, Pemenang, Gangga, Kayangan and Bayan) (KPHL RB 2012). We worked closely with the KPHL RB to identify appropriate administrative villages and hamlets within the forest management unit.
We selected 13 villages (and 14 study sites) among the 38 administrative villages around the KPHL RB (see Figure 6.1). The locations for focus group discussions (FGDs) and household surveys were selected for representation and diversity, based on their proximity to forests with different designated functions (HL and HP) and forest governance status (e.g. HKm, HTI, HA and KPH).

Each of the FGDs was attended by at least 25 participants, and we sought balanced representation in terms of age, livelihood activities and income levels, and local/indigenous people and migrants. However, we acknowledge that most of the FGD participants were men, and we did not conduct separate FGDs for women. For household-level surveys, we selected 420 households from among the 14 study sites ( 30 households per site), and these households consisted of two groups - families working within, and those working outside the forest area. The proportion of those whose livelihoods depend on resources within the forest area is about $70 \%$, or 292 households, and the remainder - those whose livelihoods do not directly depend on forest resources - is 128 households. Households were selected using simple random sampling for the two groups.

In this chapter, we briefly summarize the social and economic factors driving deforestation and forest degradation in the KPHL RB. In-depth analysis of both qualitative and quantitative information is ongoing, and will be developed as separate publications.

Table 6.1 presents the general profiles of the 13 villages and 14 study sites, and the summary statistics of demographic information collected through household surveys. Considering average per capita income (USD\$669/yr) and household size (3.59) (see Chapter 2), the sampled population for this study represents a range of diverse social and economic conditions (per capita income ranging USD \$2601033/yr and average household size 2.8-4.37), as well as different geographic locations, nearby forest functions and governance status. 


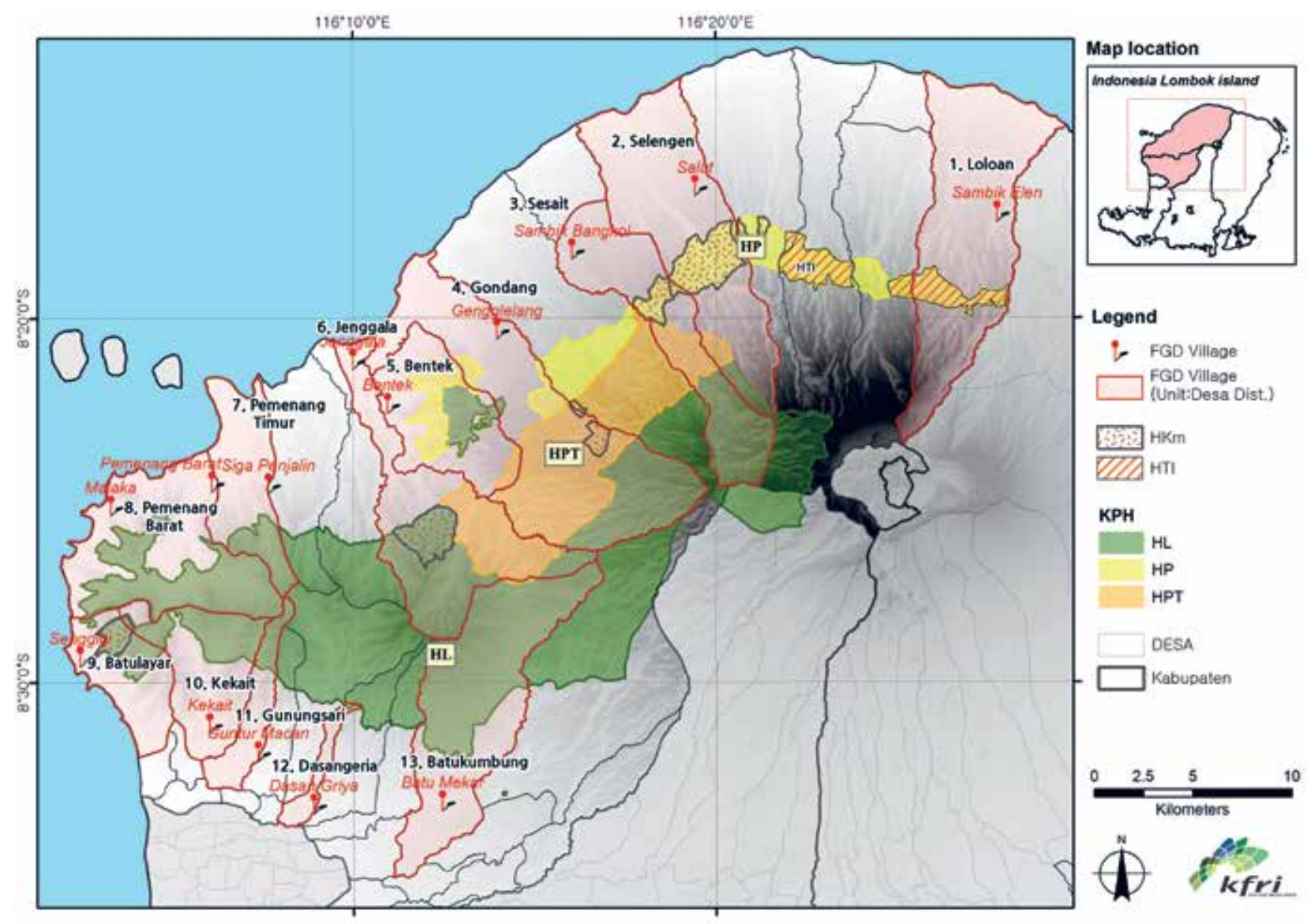

Figure 6.1 Map of study village locations

Table 6.1 Forest governance and forest functions of nearby forests for 14 FGDs and household survey locations

\begin{tabular}{lllllll}
\hline No. & Village (Desa) & FGD locations & Governance & $\begin{array}{l}\text { Nearby forest } \\
\text { function }\end{array}$ & $\begin{array}{l}\text { Household } \\
\text { sizes }^{1}\end{array}$ & $\begin{array}{l}\text { Per capita income per } \\
\text { year (USD) }\end{array}$ \\
\hline 1 & Loloan & Sambik Elen & $\mathrm{HTI}$ & $\mathrm{HP}$ & 4.03 & 482 \\
2 & Selengen & Salut & $\mathrm{HKm}$ & $\mathrm{HP}$ & 3.83 & 404 \\
3 & Sesait & Sambik Bangkol & $\mathrm{KPH}$ & $\mathrm{HL} / \mathrm{HP} / \mathrm{HPT}$ & 3.03 & 747 \\
4 & Gondang & Genggelang & $\mathrm{KPH}$ & $\mathrm{HL} / \mathrm{HP} / \mathrm{HPT}$ & 3.07 & 802 \\
5 & Bentek & Bentek & $\mathrm{KPH}$ & $\mathrm{HL} / \mathrm{HP} / \mathrm{HPT}$ & 2.90 & 494 \\
6 & Jenggala & Jenggala & $\mathrm{HKm}$ & $\mathrm{HL} / \mathrm{HPT}$ & 4.00 & 260 \\
7 & PemenangTimur & Sigar Penjalin & $\mathrm{KPH}$ & $\mathrm{HL}$ & 4.27 & 321 \\
8 & Pemenang Barat & Pemenang & $\mathrm{KPH}$ & $\mathrm{HL}$ & 4.37 & 477 \\
& & Barat & & & & \\
9 & Pemenang Barat & Malaka & $\mathrm{KPH}$ & $\mathrm{HL}$ & 3.60 & 640 \\
10 & Batulayar & Senggigi & $\mathrm{HKm}$ & $\mathrm{HL}$ & 3.48 & 739 \\
11 & Kekait & Kekait & $\mathrm{KPH}$ & $\mathrm{HL}$ & 4.90 & 567 \\
12 & Gunungsari & Guntur Macan & $\mathrm{KPH}$ & $\mathrm{HL}$ & 2.83 & 635 \\
13 & DasanGeria & Dasan Griya & $\mathrm{KPH}$ & $\mathrm{HL}$ & 2.90 & 1,033 \\
14 & BatuKumbung & Batu Mekar & $\mathrm{KPH}$ & $\mathrm{HL}$ & 2.80 & 482 \\
\hline
\end{tabular}

* Household survey at 14 locations. 


\section{Factors driving deforestation and forest degradation}

\section{Population}

Population figures in the subdistricts surrounding the KPHL RB increased steadily during 1990 2010 , although the growth rate per year has been decreasing (see Chapter 2). With limited arable land and development opportunity, the increase in population intensifies pressure on forests to meet the growing demand for food and fuel.

Overall, population growth shows a strongly positive correlation with deforestation and forest degradation. The village of Batu Layar, the center of the Senggigi Beach resort area, shows relatively high population increase (average $4.4 \%$ per year), and a similar high rate of forest cover loss $(2.59 \%$ per year). Similarly, Batu Mekar, with a lower population increase $(0.9 \%$ per year), shows a lower rate of forest cover loss $(0.49 \%$ per year). Population increase is clearly an important driver of forest cover loss within the study area (see Table 6.2 and Figure 6.2). ${ }^{6}$

As discussed in previous chapters, the deforestation in the KPHL RB $(0.75 \%$ per year) reflects conversion to shrubland (5139 ha) and to cropland (1664 ha). Conversion to shrubland implicates large-scale wood extraction, both legal and illegal, but conversion to cropland is largely due to agricultural expansion. In most of the study villages, FGDs revealed that local community residents and outsiders (immigrants) entered into forest areas, occupying particular lands with the intention of expanding agricultural production, which, as noted in Chapter 3, has been a common phenomenon in the history of deforestation and forest degradation in the KPHL RB.

\section{Fuelwood to meet energy demand}

Local residents use fuelwood for domestic needs and industrial uses, including both home industries and larger industrial needs. Most households still use fuelwood as their primary energy source, due to its relatively easy accessibility and low (or zero) cost. Almost all families (95.8\%) gather fuelwood from their own or neighbors' farms or from nearby

6 Nevertheless, several of the vilages with high population growth are also those that have benefited from improved infracture and access. Population growth and infrastrucure improvements therefore appear to be strongly correlated in our analysis. forest areas. Fuelwood consumption by household varies between $0.025 \mathrm{~m}^{3}$ and $0.092 \mathrm{~m}^{3}$ per day, with an average of $0.074 \mathrm{~m}^{3}$ per day. However, only four (out of 349 responses) reported fuelwood consumption of more than $0.28 \mathrm{~m}^{3}$ per day, and median fuelwood consumption is $0.040 \mathrm{~m}^{3}$ per day. ${ }^{7}$ Our surveys show that $30 \%$ of households collect fuelwood from forest areas. A summary of fuelwood demand in the study area is presented in Table 6.3.

Several households reported fuelwood consumption at more than $0.1 \mathrm{~m}^{3}$ per day; this use includes local home industries producing palm sugar, tofu, tempeh, candies and other delicacies. These localized home industries appear to have a major impact on overall fuelwood consumption in forest margin communities.

However, the largest consumer of fuelwood in Lombok is the tobacco industry, as tobacco drying requires significant quantities of fuelwood (Agusdin 2012). In one of the study sites (Sambik Elen), a relatively isolated community in northern Lombok, the daily collection and transport of fuelwood was reported at between two and eight truckloads (approximately 80 to $240 \mathrm{~m}^{3}$ ) during the tobacco harvest season (July to October).

\section{Illegal logging and expansion of infrastructure}

Illegal logging still occurs widely throughout the KPHL RB (2012) and it has increased with access to advanced wood harvesting technology (particularly the use of chainsaws) and with improved roads and transportation. Infrastructure is considered a critical factor in supporting economic development, but it has had the unintended consequence of accelerating deforestation and forest degradation, as improved accessibility to better roads and markets facilitate the production, transport and trade of a variety of forest products.

While improved roads and transportation are frequently cited as direct drivers of deforestation and forest degradation (Geist and Lambin 2001) they are part of the overall marketing system that influences the exploitation of forest resources. In the KPHL RB, markets and sawmills are yet another important factor, with significant registered wood

7 By excluding the four responses with consumption greater than $0.28 \mathrm{~m}^{3}$, the daily average consumption of fuelwood is only $0.047 \mathrm{~m}^{3}$ per household. 
Table 6.2 Population growth and deforestation rate by village (desa)

\begin{tabular}{llrrrrrrrrr}
\hline \multirow{2}{*}{ Village } & \multirow{3}{*}{ Study sites } & \multicolumn{4}{c}{ Forest cover $^{1}$} & \multicolumn{4}{c}{ Population $^{2}$} \\
\cline { 2 - 10 } & Sambik Elen & $\mathbf{1 9 9 5}$ & $\mathbf{2 0 0 0}$ & $\mathbf{2 0 0 5}$ & $\mathbf{2 0 1 0}$ & ha & $\% / \mathbf{y r}$ & $\mathbf{2 0 0 0}$ & $\mathbf{2 0 1 0}$ & $\% / \mathbf{y r}$ \\
\hline Loloan & Selengen & 2,224 & 1,988 & 1,817 & -882 & -2.2 & 5,527 & 6,812 & 2.3 \\
Sesait & Salut & 3,650 & 2,913 & 2,711 & 2,605 & $-1,045.2$ & -1.91 & 7,394 & 8,406 & 1.4 \\
Gondang & Sambik Bangkol & 2,943 & 2,762 & 2,642 & 2,609 & -333.8 & -0.76 & 5,900 & 5,969 & 0.1 \\
Bentek & Genggelang & 6,683 & 6,294 & 5,730 & 5710 & -972.7 & -0.97 & 9,145 & 10,566 & 1.6 \\
Jenggala & Bentek & 2,503 & 2,263 & 2,109 & 1,950 & -553.3 & -1.47 & 7,282 & 8,099 & 1.1 \\
Pemenang Timur & Jenggala & 4,823 & 4,688 & 4,489 & 4,463 & -360.9 & -0.50 & 6,255 & 7,453 & 1.9 \\
Pemenang Barat & Sigar Penjalin & 821 & 650 & 599 & 553 & -267.4 & -2.17 & 6,526 & 7,882 & 2.1 \\
& Pemenang Barat/ & 3,193 & 2,417 & 2,156 & 1,761 & $-1,431.2$ & -2.99 & 11,651 & 13,086 & 1.2 \\
Batu layar & Malaka & & & & & & & & & \\
Kekait & Senggigi & 1,055 & 798 & 750 & 645 & -410 & -2.59 & 11,077 & 15,971 & 4.4 \\
Gunungsari & Kekait & 2,472 & 2,314 & 2,204 & 2,197 & -275.1 & -0.74 & 5,568 & 6,431 & 1.5 \\
Dasan Geria & Guntur Macan & 776 & 708 & 670 & 680 & -95.2 & -0.82 & $\mathrm{~N} / \mathrm{A}$ & 2170 & - \\
Batu Kumbung & Dasan Geria & 158 & 154 & 149 & 147 & -11.1 & -0.47 & 3,823 & 4,449 & 1.6 \\
Average & Batu Mekar & 5,422 & 4,881 & 4,775 & 5,023 & -398.8 & -0.49 & 8,095 & 8,807 & 0.9 \\
\hline
\end{tabular}

Notes:

1 Forest-cover change is the average rate of land-use class conversation (1995-2010) from primary or secondary forests to other land uses within the administrative boundary of each village (desa).

2 Population data was unavailable for many of the villages before 2000 with reshaping of administrative boundaries. Population information of Gunungsari is also unavailable in 2000.

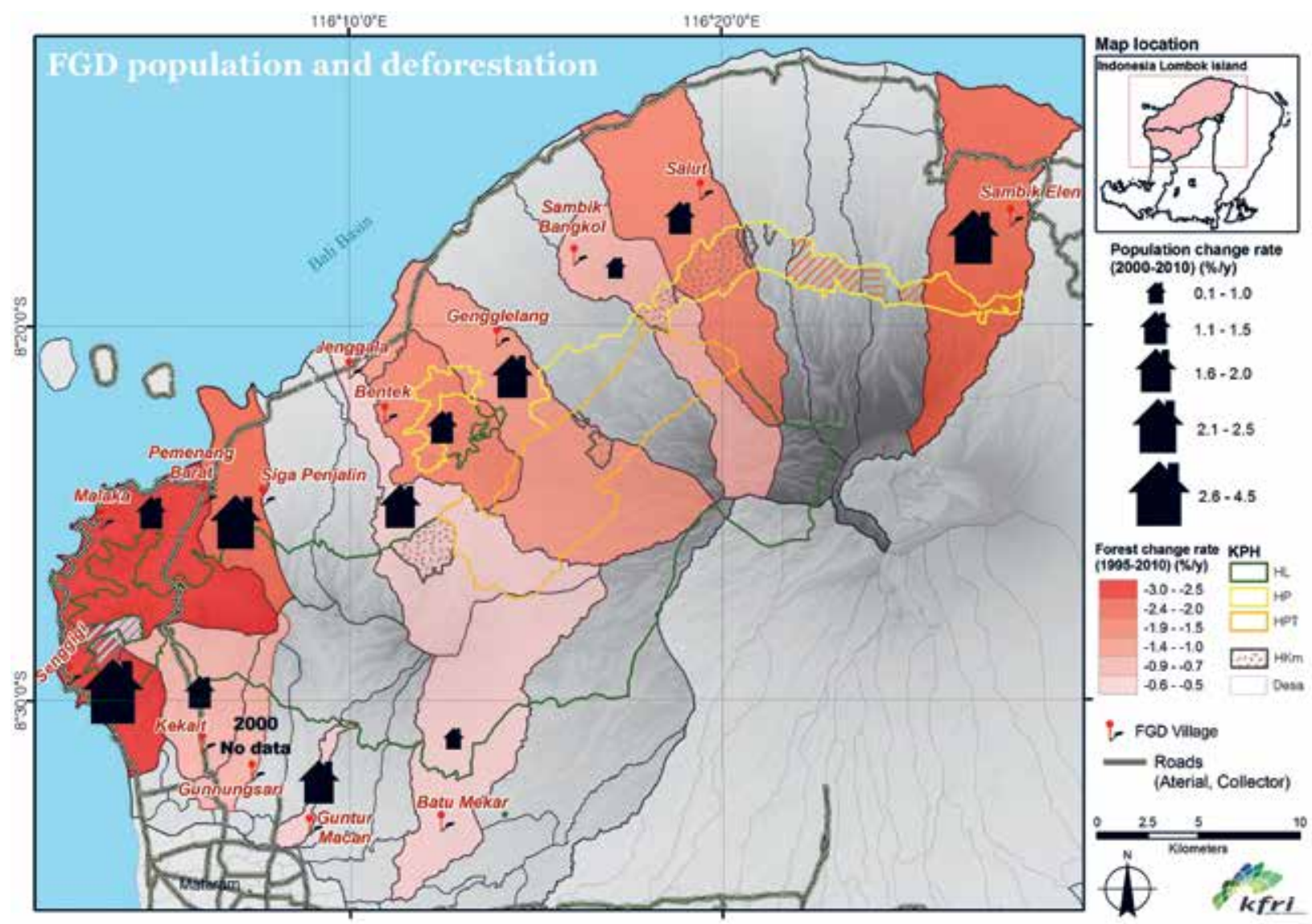

Figure 6.2 Population growth rates and forest change 
Table 6.3 Fuelwood demand within the study area

\begin{tabular}{|c|c|c|c|c|c|c|}
\hline \multirow[b]{2}{*}{ Village } & \multicolumn{2}{|c|}{ Population and household } & \multicolumn{4}{|c|}{ Fuelwood demand } \\
\hline & Population ${ }^{1}$ & $\mathrm{HH}^{2}$ & $\mathrm{~m}^{3} /$ day, $\mathrm{HH}^{3}$ & $\begin{array}{l}\mathrm{m}^{3} / \mathrm{yr} \\
\text { District }^{4}\end{array}$ & $\%$ usage $^{5}$ & $\begin{array}{l}\mathrm{m}^{3} / \mathrm{yr} \% \\
\text { District }^{6}\end{array}$ \\
\hline Sambik Elen & 6,812 & 1,892 & 0.044 & 30,389 & 100 & 30,389 \\
\hline Salut & 8,406 & 2,335 & 0.042 & 35,885 & 66 & 23,684 \\
\hline Sambik Bangkol & 5,969 & 1,658 & 0.043 & 26,256 & 87 & 22,843 \\
\hline Genggelang & 10,566 & 2,935 & 0.080 & 85,702 & 97 & 83,131 \\
\hline Bentek & 8,099 & 2,250 & 0.040 & 32,846 & 76 & 24,963 \\
\hline Jenggala & 7,453 & 2,070 & 0.036 & 26,868 & 93 & 24,987 \\
\hline Sigar Penjalin & 7,882 & 2,189 & 0.025 & 20,218 & 100 & 20,218 \\
\hline Pemenang Barat ${ }^{7)}$ & 13,086 & 3,635 & 0.064 & 84,914 & 99 & 83,640 \\
\hline Senggigi & 15,971 & 4,436 & 0.080 & 129,543 & 48 & 62,181 \\
\hline Kekait & 6,431 & 1,786 & 0.056 & 36,514 & 33 & 12,050 \\
\hline Guntur Macan & 2,170 & 603 & 0.028 & 6,147 & 60 & 3,688 \\
\hline Dasan Griya & 4,449 & 1,236 & 0.092 & 41,342 & 77 & 31,833 \\
\hline Batu Mekar & 8,807 & 2,446 & 0.044 & 39,024 & 90 & 35,122 \\
\hline KPHL RB & Total & & & & & 458,729 \\
\hline
\end{tabular}

Notes:

1 From NTB province statistics.

2 According to $\mathrm{HH}$ survey, average number of family in each household was 3.56.

3 From HH surveys.

4 Daily consumption of fuelwood $\times 365$ days $\times$ number of household in 2010 .

5 Percent households using fuelwood for cooking, based on household surveys.

6 Adjusted demand of fuelwood by \% use.

7 Pemenang Barat includes two study sites: Pemenang Barat and Malaka.

industries, primarily for furniture making and home construction materials found in Mataram City and in North Lombok (Dinas Kehutanan 2011). These local enterprises utilize and sell both local and imported wood products.

Sawmills in forest margin communities - both legal and illegal - can accelerate deforestation and forest degradation, given the growing demand for forest products for both local use and wider consumption. Access to new, lower cost and more efficient equipment has enabled the emergence of mobile sawmills that expand the range of timber harvesting and processing. FGDs in Pemenang Barat and Senggigi communities with access to major roads and tourism development, revealed that several of these local sawmills were issued official permits by local government agencies, but these enterprises are more temporary in character; no permanent and permitted enterprises were found within the study area.
As has been reported in other parts of Indonesia (Smith et al. 2003), illegal logging became particularly prevalent following the fall of Suharto, given the political uncertainty, weak local governance and widespread corruption. Addressing the challenges of illegal logging requires strong forest governance institutions, including enhanced law enforcement and regulation of the illegal timber trade, and these are important current priorities for the KPHL RB (KPH 2011).

\section{Land tenure}

Legally, jurisdiction over forest area and land is regarded as clear and definitive: land within the forest area is under the authority of the Indonesian Government, and no individual can claim ownership or change the status of forest ownership by the State.

Nevertheless, every village within the study area has experienced significant encroachment, occupation 
and settlement of forest areas. Perceived uncertainty and/or conflict over forest status, boundaries, and use rights have resulted in varied interpretation of boundaries, jurisdictions, and ownership and access rights within forest margin communities. It was also apparent from our FGDs and interviews that local knowledge about government laws and policies related to forest management is often quite limited.

The perception of land tenure security clearly affects encroachment into forest areas. Many people were reported to have occupied forest areas based on their understanding that the forest area is government land (GG), and they believe that the status of the land can be changed through continued settlement and cultivation, to the point of securing a legal claim and certificate or deed. ${ }^{8}$

Land tenure conflicts of varying degrees of intensity have occurred in several locations within the KPHL $\mathrm{RB}$ during the period of analysis (KPH 2011). For example, when the forest concession withdrew in Ganggelang Village in 2000, many local residents felt justified in occupying the abandoned forest area, and expected the government to eventually issue tax certifications (Surat Pemberitahuan Pajak Tanah or SPPT), the first step toward land transfer and ownership, as full legal ownership is predicated on the issuance of this tax certification. In other villages, community occupation of forest areas occurred with the simple intention of fulfilling basic livelihood needs. Even in communities such as Baru Murmas, a relatively isolated Buddhist community where local people have traditionally managed portions of the forest as sacred or customary forests, massive encroachment occurred in 1998 with the political turmoil following the fall of the new order regime and the absence of central government control. As one participant noted during a FGD: "We felt that if we didn't cut the trees, someone else would..."

In these latter cases, individuals recognized that the land they occupied was within designated forest areas, and they generally accepted a range of government management directives and activities (primarily reforestation projects). People who participated in these forest management projects formed farmer working groups (kelompok tani), both for the benefits of cooperation and to improve

8 Historically, the perception of GG land was that it was available to individuals as long as they cultivated the land productively but ownership status could only be changed by government decree. their bargaining position with the government or other outside entities. Many of these participated in projects implemented by the government Forest Service or by NGOs. The total area for these activities is estimated at 14,627 ha (KPHL RB 2011).

Conflicts also occurred in a number of areas with lower levels of encroachment and occupation, for example in Sambik Bangkol and Sambik Elen, Villages with greater numbers of migrants from other parts of Lombok and from Bali. In many communities where this encroachment occurred, individuals still viewed the forest as GG (and thus open to settlement), while others understood that the forest was under Indonesian Government control. Some followed project guidelines as outlined above (i.e. reforestation as government initiative, with some latitude in selection of cultivated species), while others built semipermanent structures and were clearly seeking formal ownership in addition to their short-term economic interests.

More open and acute conflicts occurred in several locations, where occupation has included features of more permanent settlements, including homes, mosques and even hotels. In these locations, almost $90 \%$ of those occupying the forest originated from other parts of Lombok, and they are reported to have regarded the forest area as GG land, available for occupation and settlement. Their intention was to obtain certification and ownership, and they organized themselves into advocacy groups, often with NGO assistance. The Forest Service generally avoided these areas and did not undertake project activities there.

While our analysis underscores the conclusion that forest occupation and land-use conflicts were precipitated by a number of factors, the most commonly noted reference point in many discussions and interviews was the experience in Rempek (not part of the village study sample), where individuals were granted ownership certificates for 86 ha in 1984 through the National Agrarian Program (PRONA) (KPHL RB 2011). Many who occupied forest areas claimed to be motivated by the Rempek example, seeking similar legal rights to their forest gardens. Although many of those who encroached into forest areas withdrew their claims when ownership certification in Rempek was withdrawn, the Forest Service was slow to respond to the situation, leaving the impression that individuals could successfully occupy forest areas and eventually secure ownership rights. A related factor that precipitated occupation 
was the general sense that the government maintained a very limited presence in these areas, with minimal supervision and enforcement capability, therefore tacitly encouraging settlement. This was particularly true during the transition period, 1998-2002.

Absent improvements in both legal clarity and local understanding of land tenure, and without a consistent official presence and enforcement of laws and policies, the problems with encroachment and occupation will certainly continue. Many local residents maintain hope that their claims will ultimately be validated; many others continue to access the forest illegally, both for temporary needs and for more sustained occupation.

\section{Other factors}

In addition to the drivers described above, a number of other factors are worth noting that have influenced deforestation and forest degradation in the KPHL RB. Permitted forest clearing by HPH and HTI concessions, without required reforestation efforts, ineffective forest management institutions, pressure for agricultural expansion, inconsistent (and sometimes contradictory) government programs, and weak law, enforcement have all contributed to the extensive forest loss and conversion that has taken place within the KPHL RB.

Communities have reclaimed the forest area that was cleared and then abandoned by the $\mathrm{HPH}$ and HTI. The lack of forest cover made it easier for local residents to move into these areas and convert these former forests into farms, agroforests and settlements. The occupation of these areas occurred during the period of political reform, when the concession holders withdrew.

Individuals moved into these forest areas, further cleared the forest vegetation and cultivated the land, despite the lack of authorization. Communities often took it upon themselves to divide the forest area among their residents, recognizing both their immediate livelihood needs as well as their long-term interest in securing tenure. They initially planted annuals and short-term tree crops for food and cash income, but with the approval of $\mathrm{HKm}$ projects, the government began encouraging the planting of designated forest tree species and a range of beneficial multipurpose tree crops. Over time, much of these converted forest lands, in both $\mathrm{HKm}$ sites and elsewhere, were transferred and/or sold to farmers from outside these communities.
The lack of strong forest management institutions is another reason for the extensive forest cover change that has taken place in the KPHL RB. This can be seen in the limited institutional management capacity, both organizationally and in terms of human resources in the forestry sector. Weak forest management capacity can be seen in the lack of clarity on forest boundaries, inconsistency in the permitting process, a lack of transparency and accountability, and contradictory authority between local and national government units.

Weak regulatory and law enforcement capacity further exacerbate the institutional problems described above. Forestry-related offenses committed by various parties within the forest, such as illegal logging, unauthorized clearing of forest areas for agriculture, setting of forest fires, illegal exploitation and transport of forest products, and illegal use of chain saws and other equipment, have all continued over the past 20 years (1990-2010), despite the fact that forest boundaries, classes and management actions have been formally established by the Ministry of Forestry. The legal framework for forest management is undermined by the weak institutional and enforcement capacity, and the inability to enforce sanctions and take legal action against law breakers. One indication of the weakness of the system can be seen in Table 6.4, which shows the limited number of convictions for forestry-related offenses. Many of our discussions and interviews reinforced a lack of public confidence and a general sense of neglect of forest management by government agencies, and many

Table 6.4 Adjudication of forestry-related offenses in NTB (2002-2011)

\begin{tabular}{cccc}
\hline Year & $\begin{array}{c}\text { Number of } \\
\text { cases }\end{array}$ & $\begin{array}{c}\text { Number of } \\
\text { accused }\end{array}$ & $\begin{array}{c}\text { Number } \\
\text { sentenced }\end{array}$ \\
\hline 2002 & 120 & 158 & 16 \\
2003 & 103 & 339 & 13 \\
2004 & 125 & 118 & 38 \\
2005 & 223 & 201 & 97 \\
2006 & 127 & 114 & 33 \\
2007 & 105 & 108 & 10 \\
2008 & 66 & 79 & 9 \\
2009 & 71 & 68 & 23 \\
2010 & 41 & 24 & 21 \\
2011 & 13 & 15 & 3 \\
\hline
\end{tabular}

Source: Dinas Kehutanan Provinsi NTB (2011) 
people clearly believe the government is incapable of effectively prosecuting wrongdoers, which sends a message of tacit acceptance of these illegal activities. These conditions have certainly contributed to the deforestation and forest degradation that we have described for the KPHL RB.

\section{Conclusion}

The success of future approaches to reduced deforestation and forest degradation, including REDD+ initiatives, depends on a thorough understanding of the factors that have led to the current state of forest management. Addressing population growth, improving the general welfare of forest margin communities, reducing poverty, and seeking new sources of energy to substitute for the dependency on fuelwood use, are all important considerations in developing strategies to reduce pressure on dwindling forest resources. Enhanced efforts at building capacity -both institutional and individual- the application of new information technologies, and improved law enforcement, are additional elements of an effective future approach. The complexity of both problems and potential solutions requires renewed efforts to improve coordination among agencies, and increased participation of all affected stakeholders. 


\section{Reference emission level and compensation options}

\section{Estimating reference emission level}

There are several well-established international carbon standards used in voluntary carbon markets. These standards provide the basic methods and best practices to design robust REDD+ methodologies to establish a REL to ensure additionality, prevent leakage, and assess permanence and risk of the proposed activities (Estrada 2010). In the absence of a unifying international agreement on carbon accounting, following VCS guidelines may be the best available option for project-level REDD+ activities (Ashton et al. 2009). We have generally followed the latest VCS guidelines for estimating baseline carbon stock changes from unplanned frontier deforestation and forest degradation from unsustainable fuelwood collection. ${ }^{9}$

We have calculated REL-based projected land-use and land-cover (LU/LC) change, and the associated carbon stock change. In addition to the project area, the KPHL RB (41,000 ha), the analysis area includes a potential leakage belt, a contiguous area containing the population census units (subdistrict or kecamatan) around the KPHL RB. The total analysis area is about 265,000 ha, and forest area accounted for 110,000 ha in 2010. Based on population data from 2000 and $2010,{ }^{10}$ we have projected future population and resulting changes in forest $\operatorname{cover}^{11}$ and accumulated fuelwood consumption from 2015 to 2045 , using a potential project period of 30 years.

Based on household surveys, most of the respondents have lived in their communities since birth $(74 \%)$ or more than 10 years $(18 \%)$, indicating that natural population growth is the main source of population pressure on forests, rather than in-migration or

9 The sources include VCS Sectoral Scope 14: Agriculture, Forestry, Land Use, specifically VM0007 REDD+ Methodology Modules (REDD+-MF), v1.4, including estimation of baseline carbon stock changes and greenhouse gas emissions from unplanned deforestation (BL-UP), v3.2; and estimation of baseline emissions from forest degradation caused by extraction of wood for fuel (BL-DFW), v1.0 .

10 BPS, Population Censuses 2000, 2010 and Inter census survey 2005.

11 Population Driver Approach by VCS projecting new forest cultivation need per new household. relocation for the last 10 years. However, inmigration could explain much of the deforestation before 2000, as described in Chapter 3. The proportion of the population that encroached and cultivated forests was about $70 \%$ and among those, new cultivation during the last 10 years accounts for $34 \%$, with an average 0.83 ha of forest land. Thus new cultivation in the forest necessary to accommodate a new household would be 0.20 ha, ${ }^{12}$ with average household size of 3.57. According to official census data, $51.5 \%$ of the population in the area reported agriculture as their main occupation. To be conservative, we took this proportion to calculate new forest clearing demands due to population increase.

With this method, the total new forest land cultivated in the first 10 years of the project period (2015-2025) would be close to 3600 ha $(8.7 \%$ of forest) in the project area and 7200 ha $(6.5 \%$ of total forest) in the larger area (Table 7.1). By the end of the 30-year project period, about 14,000 ha of the project area and almost 27,000 ha of the analysis area would be newly cultivated. In other words, more than one-third of the project area would be cultivated by 2045 , without intervention. If REDD+ activities focus solely on the KPHL $\mathrm{RB}$, without addressing the livelihood needs of the increasing population, we may simply shift new cultivation of forests outside of the KPHL RB, and the overall rate of new forest cultivation may not change from the projected $25 \%$ of forest being cleared from 2015 to 2045 in the analysis area.

As discussed in Chapter 4, the observed pattern of deforestation around the KPHL RB is gradual conversion of forests to agricultural uses, with shrubland being an intermediate land-use. We allocated the projected forest loss into two land-use classes (shrubland and all other land uses). Table 7.2 presents the area-weighted average of carbon stock. The total carbon loss from deforestation is estimated to be 2 million metric $\mathrm{tCO}_{2}$ in the project area for the first 10 years, and 9 million metric $\mathrm{tCO}_{2}$ for the project period, which is the

120.83 ha $\times 70 \% \times 4 \%$ 
Table 7.1 Annual areas of unplanned deforestation: Population driver approach (ha)

\begin{tabular}{|c|c|c|c|c|c|c|c|c|}
\hline \multirow{2}{*}{$\begin{array}{l}\text { Subdistrict } \\
\text { (Kecamatan) }\end{array}$} & \multicolumn{6}{|c|}{ Population } & \multicolumn{2}{|c|}{ New forest cultivation } \\
\hline & 2000 & 2010 & $\% / y r$ & 2015 & 2025 & 2045 & 2015-2025 & 2015-2045 \\
\hline Aikmel & 81,993 & 92,853 & 1.32 & 99,167 & 113,113 & 147,164 & 392 & 1,349 \\
\hline Batukliang & 63,596 & 71,512 & 1.24 & 76,075 & 86,093 & 110,259 & 282 & 961 \\
\hline $\begin{array}{l}\text { Batukliang } \\
\text { Utara }\end{array}$ & 40,260 & 47,268 & 1.74 & 51,528 & 61,233 & 86,473 & 273 & 982 \\
\hline Batulayar & 31,841 & 45,388 & 4.25 & 55,900 & 84,792 & 195,091 & 813 & 3,913 \\
\hline Bayan & 37,825 & 44,671 & 1.81 & 48,863 & 58,462 & 83,691 & 270 & 979 \\
\hline Gangga & 36,614 & 40,836 & 1.15 & 43,245 & 48,499 & 60,998 & 148 & 499 \\
\hline Gunungsari & 60,585 & 78,663 & 2.98 & 91,121 & 122,269 & 220,148 & 876 & 3,627 \\
\hline Kayangan & 32,414 & 37,413 & 1.54 & 40,388 & 47,068 & 63,923 & 188 & 662 \\
\hline Kopang & 67,408 & 75,719 & 1.23 & 80,503 & 90,998 & 116,271 & 295 & 1,005 \\
\hline Lingsar & 54,085 & 63,409 & 1.72 & 69,066 & 81,941 & 115,336 & 362 & 1,301 \\
\hline Masbagik & 82,541 & 93,993 & 1.39 & 100,697 & 115,573 & 152,244 & 419 & 1,449 \\
\hline $\begin{array}{l}\text { Montong } \\
\text { Gading }\end{array}$ & 33,280 & 40,603 & 2.20 & 45,271 & 56,279 & 86,977 & 310 & 1,172 \\
\hline Narmada & 76,841 & 87,897 & 1.44 & 94,405 & 108,902 & 144,917 & 408 & 1,420 \\
\hline Pemenang & 26,798 & 32,546 & 2.14 & 36,189 & 44,746 & 68,405 & 241 & 906 \\
\hline Pringgabaya & 81,920 & 90,548 & 1.05 & 95,418 & 105,957 & 130,658 & 297 & 991 \\
\hline Pringgarata & 52,408 & 62,841 & 1.99 & 69,350 & 84,460 & 125,276 & 425 & 1,572 \\
\hline Pringgasela & 44,168 & 50,059 & 1.33 & 53,488 & 61,065 & 79,594 & 213 & 734 \\
\hline Sambelia & 24,779 & 29,422 & 1.87 & 32,284 & 38,869 & 56,345 & 185 & 676 \\
\hline Sembalun & 16,663 & 18,786 & 1.27 & 20,014 & 22,715 & 29,260 & 76 & 260 \\
\hline Sikur & 62,278 & 67,550 & 0.85 & 70,458 & 76,655 & 90,732 & 174 & 570 \\
\hline Suela & 33,548 & 37,441 & 1.16 & 39,664 & 44,515 & 56,069 & 136 & 461 \\
\hline Tanjung & 38,032 & 44,606 & 1.73 & 48,597 & 57,681 & 81,263 & 256 & 918 \\
\hline Wanasaba & 54,864 & 59,317 & 0.81 & 61,764 & 66,964 & 78,714 & 146 & 477 \\
\hline KPHL RB only & 395,035 & 475,429 & 2.09 & 527,775 & 654,360 & $1,033,772$ & 3,561 & 14,225 \\
\hline $\begin{array}{l}\text { All analysis } \\
\text { areas total }\end{array}$ & $1,134,741$ & $1,313,341$ & 1.66 & $1,423,455$ & $1,678,851$ & $2,379,806$ & 7,185 & 26,885 \\
\hline
\end{tabular}

Table 7.2 Land-use change and carbon stock changes

\begin{tabular}{llrrrr}
\hline & & \multicolumn{2}{c}{$\mathbf{2 0 1 5 - 2 0 2 5}$} & \multicolumn{2}{c}{$\mathbf{2 0 1 5 - 2 0 4 5}$} \\
\cline { 3 - 6 } & & Project area & Analysis area & Project area & Analysis area \\
\hline $\begin{array}{l}\text { Projected land-use } \\
\text { change (ha) }\end{array}$ & Forest & $-3,561$ & $-7,185$ & $-14,225$ & $-26,885$ \\
& Shrubland & 1,967 & 3,969 & 7,858 & 14,852 \\
& All others & 1,594 & 3,216 & 6,367 & 12,033 \\
\hline $\left.\begin{array}{l}\text { Projected carbon change } \\
(\mathrm{tCO}\end{array}\right)$ & Forest & $-3,979,222$ & $-8,028,842$ & $-15,895,655$ & $-30,042,509$ \\
& Shrubland & $1,083,654$ & $2,186,479$ & $4,328,832$ & $8,181,417$ \\
& All others & 668,342 & $1,348,509$ & $2,669,804$ & $5,045,882$ \\
& Total Change & $-2,227,226$ & $-4,493,855$ & $-8,897,019$ & $-16,815,210$ \\
\hline
\end{tabular}


Table 7.3 Projected emissions from fuelwood consumption in the project area

\begin{tabular}{|c|c|c|c|c|c|c|}
\hline Year & 2000 & 2005 & 2010 & 2015 & 2025 & 2045 \\
\hline Number of households & 110,654 & 122,795 & 133,173 & 147,836 & 183,294 & 289,572 \\
\hline Fuelwood consumption $\left(\mathrm{m}^{3}\right)$ & 304,741 & 338,178 & 366,758 & 407,140 & 504,792 & 797,481 \\
\hline Emission per year (metric $\mathrm{tCO}_{2}$ ) & 299,347 & 332,192 & 360,267 & 399,934 & 495,857 & 783,366 \\
\hline \multicolumn{5}{|c|}{ Accumulated emissions from 2015} & $4,478,954$ & $16,791,567$ \\
\hline
\end{tabular}

equivalent of consuming 21 million barrels of oil or annual greenhouse gas emissions from 1.9 million passenger cars.

\section{Annual rate of fuelwood demand and carbon loss}

Over $80 \%$ of households surveyed reported that they use fuelwood for cooking, and they report an average consumption of $15.3 \mathrm{~m}^{3} / \mathrm{yr}$, which is likely to include relatively large energy consumers for home industries such as candy, tofu, tempeh, palm sugar production and tobacco drying. Among all fuelwood consumers, we assumed the portion of unsustainable collection to be $18 \% .{ }^{13}$ Based on our observations and the opinion of local experts, we can reasonably expect that much of the fuelwood purchased from markets and collected for sale may be from unsustainable sources. The REL will need to be reexamined with better understanding of fuelwood demand and supply sources, including illegal logging activities. Here we calculated net carbon emissions based on total fuelwood consumption self-collected in the forest. ${ }^{14}$ According to this calculation, carbon emissions from degradation caused by unsustainable fuelwood collection would reach half a million metric $\mathrm{tCO}_{2}$ in 2025. The accumulated emissions during the first 10 years, and over the entire project period in the project area alone would be 4.5 million metric $\mathrm{tCO}_{2}$, and 16.8 million metric $\mathrm{tCO}_{2}$ (Table 7.3).

The potential carbon emission reduction in the analysis area through reducing fuelwood consumption could therefore be very significant - more than twice the amount from reducing deforestation.

$1376 \%$ reported self-collection, and $24 \%$ collection from forests.

14 VCS default value of $0.47 \mathrm{tC} / \mathrm{tdm}$ for carbon fraction of dry matter; regional average of $0.57 \mathrm{dm}^{-3}$ for tropical Asia for the mean wood density (Brown 1997).

\section{REDD+ compensation for climate mitigation: For what?}

Together, the reference emission level was conservatively estimated at 25.7 million metric $\mathrm{tCO}_{2}$. The global average price for forest carbon offset was US\$7.8/metric $\mathrm{tCO}_{2} \mathrm{e}$ in 2012 . The price fell from US\$9.2/metric $\mathrm{tCO}_{2} \mathrm{e}$ in 2011, but it is still higher than the US\$5.9/metric $\mathrm{tCO}_{2} \mathrm{e}$, average price for carbon from other types of projects (PetersStanley et al. 2013). Although the level of possible carbon emission reduction will depend on the type and extent of potential compensation options, the range of expected values of carbon can be projected based on expected market values (Table 7.4). Even at the lower end of carbon price and emission reduction, we can expect at least US\$12 million of expected value generated by a REDD+ project.

If an initial investment of US $\$ 1$ million can reduce $10 \%$ of REL, we can expect at least sevenfold return in 30 years at $3 \%$ discount rate (Table 7.5). The $3 \%$ discount rate is a reflection of time preference for monetary investment, and does not account for performance risk factors. ${ }^{15}$

\section{REDD+ compensation for climate mitigation: How and how much?}

As summarized in previous chapters, the patterns of deforestation and forest degradation around

15 Conventional discount rate applied or private investment in volatile markets in developing countries could be as high as $15-17 \%$. Even with a $20 \%$ discount rate, NPV of US $\$ 1$ million initial investment is still positive at US\$1.3 million ( $10 \%$ reduction at US $\$ 5$ per metric $\left.\mathrm{tCO}_{2} \mathrm{e}\right)$. VCS guidelines recommend addressing performance risk via buffering. Overall risk is a weighted sum of the ratings on the different risk categories. Increased overall risk rating would raise the buffer withholding percentage, meaning "based on the project's overall risk classification, the percentage of carbon credits generated by the approved project activity that must be deposited into an account to cover non-permanence related project risks" (VCS 2010). 
Table 7.4 Potential market values of carbon emission reduction (US\$ millions)

\begin{tabular}{|c|c|c|c|c|}
\hline \multirow{2}{*}{$\begin{array}{l}\text { Carbon } \\
\text { price }\end{array}$} & \multicolumn{4}{|c|}{ Rate of emission reduction (avoided emission per year) } \\
\hline & $\begin{array}{c}10 \% \\
\left(86 \mathrm{Kt} \mathrm{CO}_{2} / \mathrm{yr}\right)\end{array}$ & $\begin{array}{c}20 \% \\
\left(171 \mathrm{Kt} \mathrm{CO}_{2} / \mathrm{yr}\right)\end{array}$ & $\begin{array}{c}30 \% \\
\left(257 \mathrm{Kt} \mathrm{CO}_{2} / \mathrm{yr}\right)\end{array}$ & $\begin{array}{c}50 \% \\
\left(428 \mathrm{Kt} \mathrm{CO}_{2} / \mathrm{yr}\right)\end{array}$ \\
\hline$\$ 5$ & $\$ 12.84$ & $\$ 25.69$ & $\$ 38.53$ & $\$ 64.22$ \\
\hline$\$ 7.5$ & $\$ 19.27$ & $\$ 38.53$ & $\$ 57.80$ & $\$ 96.33$ \\
\hline$\$ 10$ & $\$ 25.69$ & $\$ 51.38$ & $\$ 77.07$ & $\$ 128.44$ \\
\hline
\end{tabular}

Table 7.5 Net present value of US\$1 million investment at 3\% discount rate over 30-year project period

\begin{tabular}{|c|c|c|c|c|}
\hline \multirow{2}{*}{$\begin{array}{l}\text { Carbon } \\
\text { price } \\
\text { (US\$) }\end{array}$} & \multicolumn{4}{|c|}{ Rate of emission reduction (avoided emission per year)* } \\
\hline & $\begin{array}{c}10 \% \\
\left(86 \mathrm{Kt} \mathrm{CO}_{2} / \mathrm{yr}\right)\end{array}$ & $\begin{array}{c}20 \% \\
\left(171 \mathrm{Kt} \mathrm{CO}_{2} / \mathrm{yr}\right)\end{array}$ & $\begin{array}{c}30 \% \\
\left(257 \mathrm{Kt} \mathrm{CO}_{2} / \mathrm{yr}\right)\end{array}$ & $\begin{array}{c}50 \% \\
\left(428 \mathrm{Kt} \mathrm{CO}_{2} / \mathrm{yr}\right)\end{array}$ \\
\hline$\$ 5$ & $\$ 7.42$ & $\$ 15.81$ & $\$ 24.20$ & $\$ 40.99$ \\
\hline$\$ 7.5$ & $\$ 11.62$ & $\$ 24.20$ & $\$ 36.79$ & $\$ 61.97$ \\
\hline$\$ 10$ & $\$ 15.81$ & $\$ 32.60$ & $\$ 49.38$ & $\$ 82.95$ \\
\hline
\end{tabular}

* Emission reduction evenly distributed over the 30 -year project period

the KPHL RB show continuous unplanned encroachment by local communities around the boundaries of forests. Direct interventions limiting illegal cultivation, firewood collection and logging with increased enforcement is an important component of the overall REDD+ activities. However, reversing this trend of deforestation and forest degradation would have to address at least some of underlying drivers, such as population growth, persistent and widespread poverty and insecure land tenure (Chapter 6).

Our goals are to develop a successful bottom-up approach in REDD+ project design that can balance the needs of local communities (livelihood), with those of external funders (demonstrable results in carbon emission reduction) where the local $\mathrm{KPH}$ is bridging these interests. Thus, project activities should be designed to address the critical institutional and technical capacities of the $\mathrm{KPH}$ and improve forest governance, the key starting point of any external intervention.

\section{Build institutional and technical capacity of the KPHL RB}

Although the KPH system is a key element of forest governance reform in Indonesia, its lack of financial and human resources as well as technical capacity for management pose many challenges (Bae et al. 2014). The $\mathrm{KPH}$ is charged with reducing the deforestation rate, promoting reforestation and recovery of degraded lands, supporting forest conservation, building safeguards into forest management, improving local communities' use of forests through the stable provision of forest products and gathering data on natural resources (MoF 2009). Even as a model KPH with some support from the central government, Madani Makarom, the head of the KPHL RB (and current coordinator of the national association of $\mathrm{KPHs}$ ) estimated that the number of his staff would need to increase ten-fold (to 332 from the current number of 32 as of 2013) before his $\mathrm{KPH}$ can accomplish the most basic operational tasks: clarifying boundaries, developing forest management plans and conducting forest inventory (personal communication from M. Makarom 7 September 2013). Technical assistance to the KPH, for example developing geographical information system (GIS) of forest boundaries and stand-level information with necessary training, could greatly assist the local $\mathrm{KPH}$ in carrying out its mandate.

In addition to enhanced capacity for forest mapping, inventory and planning, technical capacity is also needed for the KPH staff to understand and adapt national and international initiatives to the local context. If $\mathrm{KPHs}$ can provide consistent interpretation of these initiatives within the local context, and explain what REDD+ projects can and cannot be, it would reduce unrealistic expectations, as well as confusion and fear toward new government initiatives. 


\section{Assure de facto usufruct rights of the communities}

As discussed in Chapter 6, local communities around the KPHL RB, and perhaps throughout Indonesia, share a common history of an open access situation created by the political void that occurred after 1998. As described in Chapter 3, communities adjacent to the production forest in northern Lombok experienced the impact of forest concessions even prior to that time, as forest concessions used clearcutting in the 1990s, which resulted in extensive forest cover change and seriously limited access to forest resources by communities. Clearing of these areas, including sites considered sacred by local communities, resulted in violent demonstrations, which attracted external attention, and led several international and local NGOs to work with local government agencies in facilitating the establishment of the first government-recognized community forestry project $(\mathrm{HKm})$. This formal recognition of usufruct rights helped create strong, capable institutions within the communities that can manage and protect their forest areas.

However, to date, there remain few $\mathrm{HKm}$ within the KPHL RB, and the legal process of establishing $\mathrm{HKm}$ projects is extremely bureaucratic, often requiring several years for approval. In addition, many local communities lack social and cultural congruency or the technical capacity for $\mathrm{HKm}$ management. The KPHL RB's survey noted that 18,000 ha of the forest area ( $44 \%$ of total $\mathrm{KPH}$ management area) is under encroachment, and is being managed illegally by local communities. The KPH system is required by national regulation to consider environmental conditions and local communities' aspirations and cultural values, including those of indigenous peoples, and their social, cultural and economic conditions (ROI 2007, 2009). Thus working within the KPH system to develop formal and informal arrangements with local communities may be the most feasible and cost-effective strategy to navigate complex landtenure issues. One ready example of assuring de facto usufruct rights is already being implemented. In a 'mandor' (forest guard/extensionist) program implemented by the KPHL RB, each community was encouraged to recommend a mandor for their area based on criteria outlined by the KPH. The mandors are responsible for monitoring illegal activities, educating their communities and assisting with enforcement. The selection and appointment of these local mandors is one of several indications that the KPHL RB is working to assign responsibility and accountability for forest conditions to local communities, while assuring their usufruct rights. This is also a way of increasing local representation within the system created by the central government, which helps generate local support for the KPH's management activities and increases downward accountability.

\section{Look for opportunities for bundling ecosystem services for project sustainability}

Ecosystem services, such as carbon sequestration and biodiversity, have global implications, but can be abstract notions to local communities. In contrast, other ecosystem services, such as water and watershed services, can attract immediate buy-in from local participants. There is a precedent of payments for watershed services in Lombok. The establishment of the PES scheme in Lombok took almost 10 years of perseverance and involved the establishment of a multi-stakeholder group (IMP, Institusi Multi-Pihak) governing PES, including WWF, the forest agency, a mineral water company, the district government and the national park (Pirard 2012). The accumulated social capital and enhanced awareness among local residents about the possibility of monetary payments for environmental services from upper watersheds and forests can provide favorable conditions for a successful co-management program. Thus looking for opportunities to 'bundle' carbon credits with other ecosystem services is a promising approach to ensure a sustained reduction of emissions with other complementary sources of funding.

\section{Cultivate local intermediaries who can champion the project}

Considering the complex and diverse social contexts and living history of local communities around the KPHL RB, compensation options cannot take a onesize-fits-all approach. What encourages collective action in forest conservation may vary depending on the local community context. The KPHL RB will need assistance developing "voluntary, realistic, conditional" agreements with each community to set individual economic development agendas. Previous project developers of RUPES (Rewarding Upland Poor for Ecosystem Services) noted that given opportunities, most communities developed their own rules for collective action and strategies for dealing with defectors, as individual actions can affect the rewards that the community as a whole can receive (RUPES 2013).

Although the KPHL RB has been exceptional in engaging local communities, they face many 
challenges coordinating their activities across ambiguous and overlapping boundaries and jurisdictions with other local forestry agencies (Dinas Kehutanan) as well as with local communities. The $\mathrm{KPH}$ will also need help training mandors recruited from local communities to understand both the technical and administrative aspects of their jobs. By working with diverse stakeholders including NGOs and local universities, the KPHL RP can implement cost-effective monitoring strategies with communities while engaging international and local researchers for continued innovation through action-oriented research, which can in turn lower transaction and other implementation costs.

For better coordination and engagement of multiple stakeholders in REDD+ project activities, a collaborative forum can be cultivated to explicitly recognize the role of intermediaries (e.g. NGOs, government agencies, universities and local organizations), a strategy which was noted as an important aspect of pro-poor PES development (Thuy et al. 2010). Established local NGOs and organizations can play important roles in accommodating the needs and perspectives of the most marginalized populations within communities, while international NGOs and universities can assist with technical training and information dissemination. Regular meetings and joint activities through a collaborative effort would facilitate improved coordination of program activities.

\section{Develop alternative energy sources and improve efficiency}

IPCC has estimated that $67 \%$ of traditional biomass (such as unsustainably collected fuelwood) is still being used for heating and cooking in developing countries (IPCC 2010). In Asia, even though consumption of fuelwood has been declining, there may still be 1.7 billion users in 2030 (IEA 2006). Emissions from deforestation and decay of biomass accounts for about $17 \%$ of the world's GHG emissions (IPCC 2007). However, if we consider emissions from the burning of biomass for energy, the GHG emissions from the forestry sector could be as much as $30 \%$ of the total. As described above, the emission reduction potential from reducing fuelwood use in the project area is much greater than that from reducing deforestation. Thus, addressing high fuelwood demand and developing alternative energy sources and burning methods may be one of the REDD+ project activities that can be implemented in a relatively short time, and with clear, demonstrable results in terms of carbon emission reduction. To address this issue, we must examine both supply and demand sides of fuelwood consumption and related policies.

Although promoting alternative energy sources would be a clear way to reduce the demand for fuelwood, converting to different burning methods is not a simple matter. More than $80 \%$ of households around the KPHL RB are still using fuelwood as their primary energy source, despite a governmentsponsored gas conversion program distributing free propane stoves. Fuelwood is still the preferred, most accessible and inexpensive energy source around the KPHL RB for household cooking and for many small-scale home industries. Many urbanizing areas reported greater use of gas as their primary cooking fuel (e.g. $43.3 \%$ in the Senggigi areas). Certainly cost, access and reliable availability are key issues in adopting alternative energy sources.

Another way of reducing fuelwood demand is by improving the process of drying and burning biomass. Dry wood contains about $50 \%$ carbon of mass as cellulose, hemicellulose and lignin and this carbon content represents significant energy value. Inefficient fuelwood combustion can be caused by burning methods that result in significant energy loss, while incomplete combustion releases carbon monoxide and black tars, which are not only air pollutants and a health hazard for users, but also a source of GHGs. Therefore, developing more efficient ways of drying and burning fuelwood may have important multiple benefits.

On the supply side, whether or not fuelwood collected from local forests is sustainable depends on what types of biomass are collected and the difference between harvest and growth rates for the biomass species. Two policy options can be considered for the supply side: developing measures to limit harvest rates to sustainable levels, and promoting plantations to lessen the pressure on 'natural' forests (Ole Hofstad et al. 2009). Especially in Lombok, we found that shrublands created after clearing primary or secondary forests were often abandoned or converted to agricultural lands, representing significant carbon loss. Encouraging agroforestry in shrublands with consideration for fast-growing biomass species could alleviate the pressure on fuelwood supply from forests.

Policies to improve fuel efficiency and promote alternative energy sources will produce results in a relatively shorter term than the ones to address the 
supply side, especially if local governments can implement the policies consistently while ensuring that alternative energy sources are available and accessible to local communities. However, policies will have to consider income effects on marginalized groups in the population, as well as the incentives and regulations to encourage cooperation of large consumers of energy, such as the tobacco industry. To address the supply side, long-term policies for sustainable forest management are needed, making sure harvest rates are balanced with plantation and growth rates in terms of carbon.

\section{Addressing underlying drivers: Economic development, capacity building and social investment}

One of the major lessons learned from past external interventions for conservation is that many projects encouraged development of alternative livelihoods for local communities without ensuring markets for the products from these activities (Blom et al. 2010). Limited attention has been given to local priorities and needs in pre-REDD+ project design (Mustalahti et al. 2012). Local intermediaries (e.g. NGOs) can help explore new market opportunities that are viable and consistent with local communities' aspirations and needs. Small business development can also be encouraged through micro-financing programs (from banks and other smaller lending institutions), and through support for agricultural cooperatives.

Programs and activities that strengthen social safety nets and improve access and quality of health care and education for women and minorities would help reduce population growth and forest dependency and poverty. Increasing access to formal and informal education and job training would be a way to help communities take advantage of these opportunities.

Forestry is a small contributor to the larger economy in terms of official statistics (less than $1 \%$ of GDP). The province's main economic sectors are in the mining $(27.4 \%)$ and agricultural $(22.7 \%)$ sectors. These sectors and others (ecotourism, marine resources) are certainly supported by the ecosystem services provided by forests (e.g. water). Better recognition of these supporting services from forests among all government agencies would lead to improved coordination and more integrated program development, and help strengthen the institutional capacity in which the KPH must operate.

\section{How much: Opportunity costs}

If we assume that a $10 \%$ reduction of deforestation and forest degradation would directly affect nontimber forest products and fuelwood collection, the opportunity costs to the villagers would be $10 \%$ of its combined annual values at US\$ 1.2 million (Tables 7.6 and 7.7). This is based on current retail market prices (BPS 2013), which are much higher than the producer prices paid to villagers. Thus, it is within the upper range of necessary compensation. Villagers may also be able to shift their activities within the boundaries of already cultivated land or find alternative livelihood options. However, more aggressive carbon emission reduction without clear livelihood alternatives for local communities would result in greater leakage, simple shifting of activities outside the project area and drive up the market prices of these products which would encourage more encroachment of other forests in Lombok and beyond.

\section{Conclusions}

There are many contextual challenges in applying international carbon standards to a relatively small, densely populated and socially complex area such as Lombok. We have applied multiple analytical methods, using all available data to triangulate and cross-validate the results, and have taken the most reasonably conservative approach to calculate the REL.

Each method presents its own limitations, and the results reported above should not be considered as absolute values. Our intent is to provide a general picture of the probable condition of future forests around the KPHL RB. Without intervention, carbon emission from deforestation and forest degradation in the project area is conservatively estimated at 25.7 million metric $\mathrm{tCO} 2$ during the next 30 years (2015-2045). It is of course unrealistic to completely eliminate deforestation and forest degradation within the project period, but many options exist for investing in effective programs to reduce these projected impacts.

The next step is to evaluate feasible carbon emission reduction targets, which should be established with consideration of potential compensation options. REL and the level of avoided emissions, including leakage, as well as the uncertainty and risk of permanence of emission reductions, should be reevaluated after determining the type and extent of REDD+ project activities. 
Table 7.6 Most commonly collected forest products and their market values

\begin{tabular}{|c|c|c|c|c|c|c|c|}
\hline & $\begin{array}{c}\mathrm{kg} / \mathrm{yr} \\
\text { (median/ } \\
\mathrm{HH} \text { ) }\end{array}$ & $\begin{array}{l}\text { Price before } \\
\text { October } 2013 \\
\text { (IDR/kg) }\end{array}$ & $\begin{array}{c}\text { Price as of } \\
\text { November } 2013 \\
\text { (IDR/kg) }\end{array}$ & $\begin{array}{l}\% \text { of } \mathrm{HH} \\
\text { collecting } \\
\text { products }^{1}\end{array}$ & $\begin{array}{l}\text { \# of } \mathrm{HH} \\
\text { collecting } \\
\text { the } \\
\text { products }^{2}\end{array}$ & $\begin{array}{l}\text { Total } \\
\text { values/yr } \\
\text { (million } \\
\text { IDR) }{ }^{3}\end{array}$ & $\begin{array}{c}\text { Total values/ } \\
\text { yr (US\$) }\end{array}$ \\
\hline Coffee & 30 & 30,000 & 35,000 & $36.10 \%$ & 24,776 & 24,156 & $2,415,620$ \\
\hline Cacao & 25 & 8,000 & 17,500 & $23.20 \%$ & 15,915 & 5,073 & 507,305 \\
\hline Banana & 16 & 8,000 & 12,000 & $34.00 \%$ & 23,299 & 3,727 & 372,782 \\
\hline $\begin{array}{l}\text { Palm Sugar } \\
\text { (liter) }\end{array}$ & 25 & 2,000 & 5,000 & $5.00 \%$ & 3,446 & 301 & 30,149 \\
\hline Durian & 160 & 10,000 & 35,000 & $11.20 \%$ & 7,712 & 27,762 & $2,776,179$ \\
\hline Rambutan & 55 & 10,000 & 15,000 & $2.40 \%$ & 1,641 & 1,128 & 112,803 \\
\hline Melinjo & 9 & 13,000 & 15,000 & $3.80 \%$ & 2,625 & 331 & 33,078 \\
\hline Total & & & & & & 62,479 & $6,247,917$ \\
\hline \multicolumn{8}{|l|}{ Notes: } \\
\hline \multicolumn{8}{|c|}{$1 \%$ of household reporting collection of each product from forest } \\
\hline \multicolumn{8}{|c|}{2 Total number of households in the analysis area $\times 51.5 \%$ (agriculture as primary occupation) $\times \%$ reported in 1} \\
\hline \multicolumn{8}{|c|}{3 Total value $=$ quantity collected per $\mathrm{HH} \times$ average price $\times$ number of $\mathrm{HH}$ collecting that product } \\
\hline
\end{tabular}

Table 7.7 Fuelwood consumption and market value

\begin{tabular}{|c|c|c|c|c|c|c|}
\hline & $\begin{array}{c}\text { Mean / } \\
\mathrm{HH} \\
\left(\mathrm{m}^{3} / \mathrm{yr}\right)\end{array}$ & $\begin{array}{c}\text { Price, before } \\
\text { October } 2013 \\
\quad\left(\text { IDR } / \mathrm{m}^{3}\right)\end{array}$ & $\begin{array}{c}\text { Price, as of } \\
\text { November } 2013 \\
\left(\text { IDR/m }{ }^{3}\right)\end{array}$ & $\begin{array}{c}\text { No. of } \mathrm{HH} \\
\text { fuelwood as } \\
\text { primary energy } \\
\text { source }\end{array}$ & $\begin{array}{l}\text { Total Values/ } \\
\text { yr (million } \\
\text { IDR) }\end{array}$ & $\begin{array}{c}\text { Total Values/ } \\
\text { yr (USD) }{ }^{2}\end{array}$ \\
\hline Fuelwood & 15.3 & 60,000 & 80,000 & 54,867 & 58,763 & $5,876,285$ \\
\hline \multicolumn{7}{|l|}{ Notes: } \\
\hline \multicolumn{7}{|c|}{1 Total value $=$ consumption $\times$ price $\times$ no. of $\mathrm{HH}$} \\
\hline \multicolumn{7}{|c|}{2 Exchange rate: US\$1 = IDR 10,000 } \\
\hline
\end{tabular}

REDD+ as a PES scheme has attracted immediate and widespread support from various international actors frustrated with the slow progress of conservation-by-development initiatives. Nevertheless, previous failures have taught us that increasing local capacity, consistent with the larger goals of social and political progress, is not only morally just, but the only feasible way for external interventions to succeed in the long term. In fact, in a recent survey of 32 REDD + experts and project developers, "monetary benefits" was the lowest ranked criterion for REDD+ success, while "actions to improve governance and regulations" was the highest (Jaung and Bae 2012).

The residents of Lombok have seen many external interventions come and go over the years. Past failures can contribute to the collective lessons learned for future success. A fundamental lesson from this experience is that direct interventions are not enough, and investment in overall capacity building is necessary to address the underlying issues of deforestation and forest degradation. At the same time, external funders of REDD+ projects, as climate mitigation efforts, cannot be motivated without clear results shown by a reduction in carbon emissions. The continuing challenge will be in balancing these needs and establishing clear mileposts toward results-based compensation. Helping local communities understand the contours of REDD+ and engaging them in the design of REDD+ project activities is essential in developing "co-investments" for environmental stewardship, rather than simple "payments" for ecosystem services. 


\section{References}

Agrawal A, Nepstad D and Chhatre A. 2011. Reducing emissions from deforestation and forest degradation. Annual Reviews of Environment and Resources 36(1):373-396.

Angelsen A. 1995. Shifting cultivation and 'deforestation': a study from Indonesia. World Development 23(10):1713-1729.

Angelsen A and Kaimowitz D. 1999. Rethinking the causes of deforestation: lessons from economic models. World Bank Research Observer 14(1):73-98.

Arnoldo CH. 2010. The Underlying Causes of Forest Decline. CIFOR Occasional Paper No. 30. 25. Bogor, Indonesia: Center for International Forestry Research.

Ashton R, Eaton J, Negra C and Creed A. 2009. Policy brief: Tools for setting reference emission levels: A review of existing tools that can be used to set a benchmark for rewarding reduced emissions and increased sequestration of greenhouse gasses in the terrestrial system. The Terrestrial Carbon Group Project. Available at: http://theredddesk. org/sites/default/files/resources/pdf/2010/TCG_ Policy_Brief_2_Tools_for_Setting_Reference_ Emission_Levels_Jun_09.pdf

Asner GP, Knapp DE, Broadbest E, Oliviera P, Keller $M$ and Silva J. 2005. Selective logging in the Brazilian Amazon. Science 310:480-2.

Asner GP. 2001. Cloud cover in Landsat observations of the Brazilian Amazon. International Journal of Remote Sensing 22:3855-62.

Bae JS, Kim YS, Fisher LA, Moeliono M and DeShazo J. In press. Promises and Perils of Decentralized Forest Governance: The case of Indonesia's forest management units in REDD+ implementation. Society and Natural Resources.

Bae JS, Kim C, Kim YS, Latifah S, Afifi M, Fisher LA, Kang J, Kim R, Kim JS, Jang S, Lee SM and Son Y. 2013. Presentation, Lombok KPH REDD Feasibility Study - REDD Balancing: Carbon credits and livelihoods. Lombok REDD Workshop 2013 Proceedings. Seoul.

Bae JS, Kim C, Jaung W, Kim YS. Kwon J, Lee $\mathrm{CH}$ and Moeliono M. 2012. REDD+ National Strategy and Implementation in Indonesia: A preliminary feasibility study on West Rinjani Protection Forest Management Unit (KPHL Rinjani Barat) REDD project in Lombok. Korea
Forest Research Institute (KFRI) Research Paper 12-03. Seoul, Korea.

Bappeda Pemerintah Provinsi NTB. 2011.

Peraturan Daerah Provinsi Nusa Tenggara Barat Nomor 3 Tahun 2010 tentang Rencana Tata Ruang Wilayah Provinsi Nusa Tenggara Barat Tahun 2009-2029. Mataram: Bappeda NTB.

Bartlett JE, Kotrlik JW and Higgins C. 2001. Organizational research: Determining appropriate sample size for survey research. Information Technology, Learning, and Performance Journal 19(1): 43-50.

Basuki TM, van Laake PE, Skidmore AK and Hussin YA. 2009. Allometric equations for estimating the above-ground biomass in tropical lowland Dipterocarp forests: Carbon sequestration in Asian Countries. Bogor, Indonesia: Center for International Forestry Research.

Bellassen V and Gitz V. 2008. Reducing emissions from deforestation and degradation in Cameroon - assessing costs and benefits. Ecological Economics 68(1-2):336-44.

Beymer-Farris BA and Bassett TJ. 2012. The REDD menace: Resurgent protectionism in Tanzania's mangrove forests. Global Environmental Change 22(2):332-41.

BKSDA NTB. 2012. Book Information Wild Fauna and West Nusa Tenggara. Mataram: Balai Konservasi Sumberdaya Alam Nusa Tenggara Barat.

BKSDA NTB. 2013. Book Information Conservation Area West Nusa Tenggara. Mataram:Balai Konservasi Sumberdaya Alam Nusa Tenggara Barat.

Blom B, Sunderland T and Murdiyarso D. 2010. Getting REDD to work locally: lessons learned from integrated conservation and development projects. Environmental Science and Policy 13:164-172.

Boerner J, Wunder S, Wertz-Kanounnikoff S, Tito MR, Pereira L and Nascimento N. 2010. Direct conservation payments in the Brazilian Amazon: Scope and equity implications. Ecological Economics 69(6):1272-82.

BPS 2011. Nusa Tenggara Barat dalam Angka (NTB Statitics) Tahun 2011. Mataram: Badan Pusat Statistik Provinsi Nusa Tenggara Barat. 
BPS 2012. Nusa Tenggara Barat dalam Angka (NTB Statitics) Tahun 2012. Mataram: Badan Pusat Statistik Provinsi Nusa Tenggara Barat.

Brown S. 1997. Estimating biomass and biomass change of tropical forests: A primer. FAO Forestry Paper 134. Rome: Food and Agriculture Organization of the United Nations.

Burgess ND, Bahane B, Clairs T, Danielsen F, Dalsgaard S, Funder M, Hagelberg N, Harrison P, Haule C, Kabalimu K, et al. 2010. Getting ready for REDD plus in Tanzania: A case study of progress and challenges. Oryx 44(3):339-51.

[CAS] Central Agency on Statistics of Indonesia. 2014. Indonesia Human Development Index. Available at: http://www.bps.go.id/eng/ tab_sub/view.php?tabel=1\&daftar=1\&id_ subyek $=26 \&$ notab $=2$.

Cerbu GA, Swallow BM and Thompson DY. 2010. Locating REDD: A global survey and analysis of REDD readiness and demonstration activities. Environmental Science and Policy 14(2):1-13.

Chambers R. 1994. The origins and practice of participatory rural appraisal. World Development 22(7):953-69.

Chan E and Elevitch CR. 2006. Species Profiles for Pacific Island Agroforestry: Cocos nucifera (coconut). Hawaii: USA Permanent Agriculture Resources, University of Hawaii.

Chhatre A and Agrawal A. 2009. Trade-offs and synergies between carbon storage and livelihood benefits from forest commons. Proceedings of the National Academy of Science 106(42):17667-70.

Christie M, Fazey I, Cooper R, Hyde T, Deri A, Hughes L, Bush G, Brander L, Nahman A, de Lange W and Reyers B. 2008. An evaluation of economic and non-economic techniques for assessing the importance of biodiversity to people in developing countries. CR 0391 Final report. London, 118 pp.

Congalton RG. 1991. A review of assessing the accuracy of classification of remotely sensed data. Remote Sensing of Environment 37:35-46.

Crossman ND, Burkhard B, Nedkov S, Willemen S, Petz K, Palomo I, Edracou EG, MartinLopez B, McPearson T, Boyanova K et al. 2013. A Blueprint for Mapping and Modelling Ecosystem Services. Ecosystem Services 4:4-14.

Curran LM, Trigg SN, McDonald AK, Astiani D, Hardiono YM, Siregar P, Caniago I and Kasischke E. 2004. Lowland forest loss in protected areas of Indonesian Borneo. Science 303:1000-2.

Das $S$ and Singh TP. 2013. Mapping vegetation and forest types using Landsat TM in the
Western Ghat region of Maharashtra, India. International Journal of Computer Applications 76(1):33-37.

DeFries R, Achard F, Brown S, Herold M, Murdiyarso D, Schlamadinger B and Souza C. 2006. Reducing greenhouse gas emissions from deforestation in developing countries: Considerations for monitoring and measuring. GOFC-GOLD Report 26. Global Terrestrial Observing System (GTOS), Rome. 22 pp.

De Koning F, Aguinaga M, Bravo M, Chiu M, Lascano M, Lozada T and Suarez L. 2011. Bridging the gap between forest conservation and poverty alleviation: The Ecuadorian socio bosque program. Environmental Science and Policy 14(5):531-42.

Departemen Kehutanan. 1986. Sejarah Kehutanan Indonesia II-III Periode Tahun 1942-1983. Jakarta.

Djajapertjunda S. 2002. Kehutanan Indonesia dari Masa ke Masa. Bogor: IPB Press.

Dinas Kehutanan Provinsi NTB 2012. Rencana Kehutanan Tingkat Provinsi NTB 2012-2031. Mataram: Dinas Kehutanan Provinsi NTB.

Dinas Kehutanan Provinsi NTB 2011. Statistik Kehutanan Provinsi NTB Tahun 2011. Mataram: Dinas Kehutanan Provinsi NTB.

Dinas Kehutanan Provinsi NTB. 2000. Statistik Kehutanan Provinsi NTB Tahun 2000.

Mataram: Dinas Kehutanan Provinsi NTB.

Dinas Kehutanan Provinsi NTB. 1990. Statistik Kehutanan Provinsi NTB Tahun 1990.

Mataram: Dinas Kehutanan Provinsi NTB.

[DNPI] Dewan Nasional Perubahan Iklim. 2010. Indonesia's greenhouse gas abatement cost curve. DNPI, Bogor, 52 pp. Available at: http:// www.dnpi.go.id/report/DNPI-Media-Kit/ reports/indonesia-ghg_abatement_cost_curve/ Indonesia_ghg_cost_curve_english.pdf

Eggleston S, Buendia L, Miwa K, Ngara T and Tanabe K, eds. 2006. 2006 IPCC Guidelines for National Greenhouse Gas Inventories Volume 4 Agriculture, Forestry and Other Land Use. Hayama, Japan: the Institute for Global Environmental Strategies.

Estrada M. 2010. Standards and methods available for estimating project-level REDD + carbon benefits. CIFOR Working Paper No. 52. Bogor, Indonesia: Center for International Forestry Research.

Ezzine-de-Blas D, Boerner J, Violato-Espada A, Nascimento $\mathrm{N}$ and Piketty M. 2011. Forest loss and management in land reform settlements: Implications for REDD governance in the 
Brazilian amazon. Environmental Science and Policy 14(2):188-200.

Facry A, Hanartani, Supartiningsih $S$ and Butler JSA. 2011. Human, Socio-Cultural and Economic Prospects for NTB. CSIRO-AUSAIDUNRAM Climate Change Adaptaion Project Research Report. Brisbane/Lombok: University of Mataram.

Hong SK, Lee JA, Ihm BS, Farina A, Son Y, Kim ES and Choe CJ, eds. 2004. Ecological Issues in a Changing World. The Netherlands: Kluwer Academic Publishers.

[FAO] Food and Agricultural Organization. 2000. On definitions of forest and forest change. Forest Resources Assessment Programme Working Paper 33. FRA 2000. Rome: FAO, 15-6.

[FAO] Food and Agricultural Organization. 2010. Global Forest Resources Assessment 2010: Main report. FAO Forestry Paper No. 163. Rome: FAO, 340-41.

[FAO] Food and Agricultural Organization. 2001a. Global forest resources assessment 2000: main report. FAO Forestry Paper 140. Rome: FAO.

[FAO] Food and Agricultural Organization. 2001b. Forest plantation resources, FAO data-sets 1980 , 1990, 1995 and 2000. FAO Working Paper FP/14. Rome: FAO, 40-41.

[FAO] Food and Agricultural Organization. 2007. Definitional issues related to reducing emissions from deforestation in developing countries. Forest and Climate Change Working Paper 5. Rome: FAO. 29-30.

[FAO] Food and Agricultural Organization. 2010. Global Forest Resources Assessment 2010, Main report. FAO Forestry Paper 163. Rome: FAO.

Fisher B, Edwards DP, Giam X and Wilcove DS. 2011. The high costs of conserving Southeast Asia's lowland rainforests. Frontiers in Ecology and the Environment 9(6):329-34.

Foody GM. 2002. Status of land cover classification accuracy assessment. Remote Sensing of Environment 80:185-201.

Foody GM, Palubinskas G, Lucas RM, Curran PJ and Honzak M. 1996. Identifying terrestrial carbon sinks: Classification of successional stages in regenerating tropical forest from Landsat TM data. Remote Sensing of Environment 55:205-16.

Forest Carbon Asia. 2013. REDD+ project profile of Indonesia. Available at http://www. forestcarbonasia.org

Geist $\mathrm{H}$ and Lambin E. 2001. What drives tropical deforestation? A meta-analysis of proximate and underlying causes of deforestation based on subnational case study evidence. Land-Use and
Land-Cover Change (LUCC) Project. International Geosphere-Biosphere Programme (IGBP). LUCC Report Series: 4. Geist HJ and Lambin EF. 2001. What drives tropical deforestation? A meta-analysis of proximate and underlying drivers of deforestation based on sub-national case study evidence. Louvain-la-Neuve Belgium: LUCC International Project Office. 116-17.

Gibbs HK, Brown S, Niels JO and Foley JA. 2007. Monitoring and estimating tropical forest carbon stocks: making REDD a reality. Environmental Research Letters 2:045023.

Grainger A, Boucher DH, Frumhoff PC, Laurance WF, Lovejoy T, McNeely J, Nickiesch M, Raven P, Sodi NS, Ventor O and Pimm SL. 2009. Biodiversity and REDD at Copenhagen. Current Biology 19(21):R974-R976.

Griscom B, Shochb D, Stanleya B, Corteza R and Virgilioa N. 2009. Sensitivity of amounts and distribution of tropical forest carbon credits depending on baseline rules. Environmental Science and Policy 12(7):897-911.

Guariguata MR, Nasi R and Kanninen M. 2009. Forest degradation: it is not a matter of new definitions. Conservation Letters 2(6): 286-287.

Gullison RE, Frumhoff PC, Canadell JG, Christopher BF, Nepstad DC, Hayhoe K, Avissar R, Curran LM, Friedlingstein P, Jones CD and Nobre C. 2007. Tropical forests and climate policy. Science 316: 985-986.

Guo LB and Gifford RM. 2002. Soil carbon stocks and land use change: a meta analysis. Global Change Biology 8:345-360.

GOFC-GOLD. 2009. A Sourcebook of Methods and Procedures for Monitoring and Reporting Anthropogenic Greenhouse Gas Emissions and Removals Caused by Deforestation, Gains and Losses of Carbon Stocks in Forests Remaining Forests, and for Estation. Alberta, Canada: GOFC-GOLD Project Office, Natural Resources Canada.

Hajek F, Ventresca MJ, Scriven J and Castro A. 2011. Regime-building for REDD+: Evidence from a cluster of local initiatives in south-eastern Peru. Environmental Science \& Policy 14(2):201-15.

Hansen MC, Patapov PV, Moore R, Hancher M, Turubanova SA, Tyukavina A, Thau D, 
Stehman SV, Goetz SJ, Loveland TR et al. 2013. High-resolution Global Maps of 21 $1^{\text {st-Century }}$ Forest Cover Change. Science 342:850-53. Hansen MC, Roy D, Lindquist E, Justice CO and Alstaat A. 2008. A method for integrating MODIS and Landsat data for systematic monitoring of forest cover and change in the Congo Basin. Remote Sensing of Environment 112:2495-2513.

Hansen MC, Stehman SV, Potapov PV, Pittman KW, Margono AB and Stolle F. 2009. Quantifying changes in the rates of forest clearing in Indonesia from 1990 to 2005 using remotely sensed data. Environmental Research Letters 4:034001.

Harvey CA, Dickson B and Kormos C. 2010. Opportunities for achieving biodiversity conservation through REDD. Conservation Letters 3(1):53-61.

Hirata Y, Takao G, Sato T, Toriyama J, eds. 2012. REDD-plus Cookbook. Zukuba: REDD Research and Development Center, Forestry and Forest Products Research Institute.

Hofstad O, Köhlin G and Namaalwa J. 2009. How can emissions from woodfuel be reduced? Realising REDD. Bogor Indonesia: CIFOR.

Holmes D. 2002. Where have all the forests gone? Environmental and Social Development, East Asia and Pacific Region Discussion Paper. The World Bank, Washington, DC.

Huzaini M. 2002. Faktor-Faktor yang Mempengaruhi Pendapatan Rumah Tangga di Sekitar Kawasan Hutan Produksi Rempek - Monggal. Tesis (tidak dipublikasikan). Bogor: Sekolah Pasca Sarjana Institut Pertanian Bogor.

Idris MH, Yasin I, Mahrup and Abawi Y. 2011. Spatial and Temporal Pattern of Rainfall in Southern Lombok Eastern Indonesia (Pola spasial dan Temporan Curah Hujan Lombok Selatan Indonesia Timur). Jurnal Lembaga Penelitian Universitas Mataram Tahun 2(15): 71-79.

Idris MH, Mahrup I, Yasin. 2010. Biophysical Hindrances of Community Based Agroforestry Development: Case Study in Lombok. Prosiding Seminar Nasional Agroforestri II. Seminar dilaksanakan pada 27 Januari 2010. Mataram: University of Mataram.

Indrarto GB, Purba C, Steni B, Tresya D, Dewantama M, Hartati C, Rahman Y, Apriani I and Putri A. 2013. Images of Forest Governance Implementation: An In-depth Study in Central Kalimantan and West Nusa Tenggara (in Indonesian). Jakarat:Jaringan Tata Kelola Hutan Indonesia.
Indrarto GB, Murharjanti P, Khatarina J, Pulungan I, Ivalerina F, Rahman J, Prana MN, Resosudarmo IAP and Muharrom E. 2012 The Context of REDD+ in Indonesia: Drivers, agents and institutions. CIFOR Working Paper No 92. Bogor, Indonesia: Center for International Forestry Research.

[IETA] International Emissions Trading Association. 2012. GHG Market Sentiment Survey. (7th edition). 22-3.

Indonesian REDD+ Task Force. 2012. REDD+ National Strategy. Jakarta, Republic of Indonesia: BAPPENAS, 40-1. Available at http://www. satgasreddplus.org/.

[IEA] International Energy Agency. 2006. World Energy Outlook 2006. Paris, France: IEA.

[IPCC] Intergovernmental Panel on Climate Change. 2007. Climate Change 2007: Synthesis Report. Fourth Assessment Report of the IPCC, Geneva, Switzerland:IPCC.

[IPCC] Intergovernmental Panel on Climate Change. 2007a. Summary for policymakers. In: Pachauri, R., Reisinger, A. (eds.), Climate Change 2007: Synthesis Report. Intergovernmental Panel on Climate Change, 104 pp Geneva: IPCC. Available at: http://www.ipcc.ch/pdf/assessmentreport/ar4/syr/ar4_syr_spm.pdf.

[IPCC] Intergovernmental Panel on Climate Change. 2007b. Climate Change 2007: Mitigation of Climate Change. Cambridge, UK: Cambridge University Press. Available at: http://www. ipcc.ch/publications_and_data/publications_ ipcc_fourth_assessment_report_wg3_report_ mitigation_of_climate_change.htm.

[IPCC] Intergovernmental Panel on Climate Change. 2006. Guidelines for National Greenhouse Gas Inventories; Volume 4. Agriculture, Forestry and Other Land Use. Kanagawa, Japan: National Greenhouse Gas Inventories Programme.

[IPCC] Intergovernmental Panel on Climate Change. 2006. 2006 IPCC Guidelines for National Greenhouse Gas Inventories. Kanagawa, Japan: National Greenhouse Gas Inventories Programme.

[IPCC] Intergovernmental Panel on Climate Change. 2003. Good Practice Guidance for Land use, Land-use Change and Forestry. Hayama, Japan: Institute for Global Environmental Strategies.

[ITTO] International Tropical Timber Organization. 2002. ITTO guidelines for the restoration, management and rehabilitation of degraded and secondary tropical forests. Draft report of 
ITTO by an International Expert Panel. Bern, Switzerland 18-22 February 2002.

Jaya INS, Massijaya Y, Puspaningsih N, Purnama ES, Wijaya PA and Wulandri R. 2011. Analysis on land-use change using remote sensing and GIS technology. Lombok REDD project (KIPCCF). Bogor, Indonesia.

Jaung W and Bae JS. 2012. Evaluating socioeconomic equity of REDD+ in a rights-based approach: Rapid equity appraisal matrix. Environmental Science and Policy 22:1-12.

Jensen JR, Cowen DJ, Narumalani S, Althausen JD and Weatherbee O. 1993. An evaluation of Coastwatch change detection protocol in South Carolina. Photogrammatic Engineering \& Remote Sensing 59(6):1039-1046.

Jensen JR. 2005. Introductory Digital Image Processing: A Remote Sensing Perspective (3rd edn.). Upper Saddle River, NJ: Pearson Prentice Hall.

Kraan Avd. 2009. Lombok: Conquest, Colonization and Underdevelopment. Mataram: Lengge Printika.

Karky BS and Skutsch M. 2010. The cost of carbon abatement through community forest management in Nepal Himalaya. Ecological Economics 69(3):666-72.

Kartawinata K, Riswan S, Gintings AN and Puspitojati T. 2001. An overview of postextraction secondary forest in Indonesia. Journal of Tropical Forest Science 13(4):621-638.

Karsenty A and Ongolo S. 2012. Can 'fragile states' decide to reduce their deforestation? The inappropriate use of the theory of incentives with respect to the REDD mechanism. Forest Policy and Economics 18:38-45.

Kauffman JB and Donato DC. 2012. Protocols for the measurement, monitoring and reporting of structure, biomass and carbon stocks in mangrove forests. CIFOR Working Paper No. 86. Bogor, Indonesia: Center for International Forestry Research.

Ketterings QM, Wibowo TT, Van Noordwijk M and Penot E. 1999. Farmer's perspectives on slash-and-burn as a land clearing method for small-scale rubber producers in Sepunggur Jambi Province, Sumatra, Indonesia. Forest Ecology and Management 120:157-69.

Khatun K. 2011. Reconciling timber provision with carbon sequestration opportunities in the tropical forests of Central America. Environmental Science and Policy 14(8):1091-102.

Kim C, Kang J, Kim J. 2013. Land-use Change and Carbon Stock Estimation in KPHL Rinjani Barat.
Lombok REDD Workshop Proceeding: from Science to Good Practice, Seoul.

[KOICA] Korea International Cooperation Agency. 2010. Guidebook on AR CDM and REDD. Jakarta, Indonesia: KOICA.

KORINDO. 2012. REDD Regional economic development model and methodology. Final report on Korea-Indonesian Joint Project for Adaptation and mitigation of climate changes in forestry.

KORINDO. 2011. REDD Regional economic development model and methodology. Report on Lombok Project, sponsored by Korea-Indonesia Joint Project for Adaptation and Mitigation of Climate Change in Forestry (KIPCCF).

Krisnawati $\mathrm{H}$, Audinugroho WC and Imanuddin R. 2012. Allometric models for estimating tree biomass at various forest ecosystem types in Indonesia. Ministry of Forestry. 102-113.

Kumar P, Rani M, Pandey PC, Majumdar A and Nathawat MS. 2010. Monitoring of deforestation and forest degradation using remote sensing and GIS: A case study of Ranchi in Jharkhand (India). Report and Opinion 2(4):14-20.

Lambin E, Turner BL, Geist HJ, Agbola SB, Angelsen A, Bruce JW, Coomes OT, Dirzo R, Fischer G, Folke C, et al. 2001. The causes of land use and land cover change: Moving beyond the myths. Global Environmental Change 11(4):261-9.

Larson AM. 2011. Forest tenure reform in the age of climate change: Lessons for REDD+. Global Environmental Change 21(2):540-9.

Larson AM. 2005. Democratic decentralization in the forestry sector: lessons learned from Africa, Asia and Latin America. Colfer CJP and Capistrano D (eds.) The politics of decentralization: forests, power and people 32-62. London, UK: Earthscan.

Larson AM, Brockhaus M, Sunderlin WD, Duchelle A, Babon A, Dokken T, Pham TT, Resosudarmo IAP, Selaya G, Awono A and Huynh TB. 2013. Land tenure and REDD+: the good, the bad and the ugly. Global Environmental Change 23(3):678-89.

Latifah S, Afifi M and Mukarom M. 2013. How have Lombok people utilized the forest for livelihood in KPHL Rinjani Barat. Lombok REDD Workshop 2013 Proceeding. Seoul.

Leimona B, Finlayson R, Wijaya C, Prawisuda A, Duque Pinon C, Dam VB and Pasha R. 2013. rewards for, use of and shared investment. In Pro-poor Environmental Services Schemes 
(RUPES) Phase Two. Bogor, Indonesia: World Agroforestry Centre (ICRAF) Southeast Asia Regional Program .

Leitmann J et al. 2009. Investing in a more sustainable Indonesia: Country Environmental Analysis. CEA Series Report No. 50762-ID, East Asia and Pacific Region. Washington, DC. 94-95. Available at: http://reliefweb.int/sites/reliefweb. int/files/resources/006D524F9C10B2B84925767 8001B1745-Full_Report.pdf

Li G, Lu D, Moran E and Hetrick H. 2011. Landcover classification on a moist tropical region of Brazil with Landsat Thematic Mapper imagery. International Journal of Remote Sensing 32(23):8207-8230.

Lillesand TM and Kiefer RW. 1999. Remote sensing and image interpretation. New York:John Wiley and Sons.

Lindenmayer DB, Hulvey KB, Hobbs RJ, Colyvan M, Felton A, Possingham H, Steffen W, Wilson K, Youngentob K and Gibbons P. 2012. Avoiding bio-perversity from carbon sequestration solutions. Conservation Letters 5(1):28-36.

Lu D. 2005. Integration of vegetation inventory data and Landsat TM image for vegetation classification in the western Brazilian Amazon. Forest Ecology and Management 213:369-83

Lu D and Weng Q. 2007. A survey of image classification methods and techniques for improving classification performance. International Journal of Remote Sensing 28:823-70.

Lund HG. 2006. Guide for classifying lands for greenhouse gas inventories. Journal of Forestry 104(6):211-16.

Macdonald EA, Collins M, Johnson PJ, Clayton LM, Malhi Y, Fisher JB, Miller-Gulland EJ, and Macdonald DW. 2011. Wildlife conservation and reduced emissions from deforestation in a case study of Nantu National Park, Sulawesi: 1. The effectiveness of forest protection-many measures, one goal. Environmental Science and Policy 14(6): 697-708.

Margono BA, Turubanova S, Zhuravleva I, Potapov P, Tyukavina A, Caccini A, Goetz $S$ and Hansen MC. 2012. Mapping and monitoring deforestation and forest degradation in Sumatra (Indonesia) using Landsat time series data sets from 1990 to 2010. Environmental Research Letters 7:034010.

Martello R, Dargusch P and Medrilizam. 2010. A systems analysis of factors affecting leakage in reduced emissions from deforestation and degradation projects in tropical forests in developing nations. Small-Scale Forestry 9(4):501-16.
Mattsson E, Persson UM, Ostwald M and Nissanka SP. 2012. REDD plus readiness implications for Srilanka in terms of reducing deforestation. Journal of Environmental Management 100:29-40.

Miettinen J and Liew SC. 2010. Degradation and development of peatlands in peninsular Malaysia and in the islands of Sumatra and Borneo since 1990. Land Degradation and Development 21:285-96.

[MoA] Ministry of Agriculture. 1982. Agriculture Ministry Decree No. 756/Kpts/Um/10/1982: Penunjukkan Areal Hutan di Wilayah DATI I Nusa Tenggara Barat seluas $\pm 1.063 .273,2 \mathrm{Ha}$ (Satu Juta Enam Puluh Tiga Ribu Dua Ratus Tujuh Puluh Tiga koma Dua Hektar) sebagai Kawasan Hutan. Jakarta: MoA.

[MoF] Ministry of Forestry. 2013. Pembangunan KEsatuan Pengelolaan Hutan (KPH) : Konsep, Peraturan Perundangan dan Implementasi. Direktorat Wilayah Pengelolaan dan Penyiapan Areal Pemanfaatan Kawasan Hutan. Debut Wahana Sinergi. MoF, Jakarta.

[MoF] Ministry of Forestry. 2012. Data and Information on Forest Management Unit 2012. Jakarta, Indonesia. 225 pp. (in Indonesian). Available at http://www.redd-indonesia.org/ publikasi/daftar-publikasi

[MoF] Ministry of Forestry. 2011. Measurement and calculation of carbon stocks. Field measurement for estimating forest carbon stocks. The Indonesian National Standard, SNI 7724:2011.

[MoF] Ministry of Forestry. 2009. Development of $K P H$. Jakarta, Indonesia: Ministry of Forestry (in Indonesian).

[MoF] Ministry of Forestry. 2009. Forestry Ministry Decree No. No. 598/Kpts-II/2009 : Penunjukkan Kawasan Hutan dan Konservasi Perairan di Wilayah Provinsi Nusa Tenggara Barat. Jakarata: MoF.

[MoF] Ministry of Forestry. 1999. Forestry and Plantation Ministry Decree No. 418/Kpts-II/1999 : Penunjukkan Kawasan Hutan di Wilayah Propinsi Daerah Tingkat I Nusa Tenggara Barat seluas 1.021.566 (Satu Juta Dua Puluh Satu Ribu Lima Ratus Enam Puluh Enam) Hektar. MoF, Jakarta.

Mukarom M. 2013. Progress and Problems Tenurian Handling efforts at West Rinjani KPH. Presentasi pada Rapat Koordinasi Fasilitasi dan Media Permasalahan Tenurial di KPHL Rinjani Barat 45 Juli 2013. Mataram.

Mukarom M. 2012. Preconditions step that leads REDD + program in West Rinjani KPH. Proceeding on International Workshop: Indonesia's 
$R E D D+$ Strategy and Implementation, July 4 2012. Seoul.

Mustalahti I, Bolin A, Boyd E and Paavola J. 2012. Can REDD+ reconcile local priorities and needs with global mitigation benefits? Lessons from Angai Forest, Tanzania. Ecology and Society 17(1):16. Available at: http://www. ecologyandsociety.org/vol17/iss1/art16/

Niles JO, Brown S, Pretty J, Ball AS and Fay J. 2002. Potential carbon mitigation and income in developing countries from changes in use and management of agricultural and forest lands. Philosophical Transactions of the Royal Society of London, A 360:1621-39.

NORAD 2011. Real-time evaluation of Norway's international climate and forest initiative: Contributions to National REDD+ Processes 2007-2010, Country Report: Indonesia, Evaluation Report 16/2010. Norad, Oslo. 144 pp.

Nelson A and Chomitz KM. 2011. Effectiveness of strict vs. multiple use protected areas in reducing tropical forest fires: A global analysis using matching methods. PLoS One 6(8):e22722.

Noordwijk MV and Leimona B. 2010. Principles for fairness and efficiency in enhancing environmental services in Asia: Payments, compensation, or investment? Ecology and Society 15(4):17.

National Coordination Agency for Surveys and Mapping. 1975. Indonesia Soil Map B/13/01. Yogjakarta:National Coordination Agency for Surveys and Mapping and Gadjah Mada Univeristy. Available at: http://eusoils.jrc. ec.europa.eu/esdb_archive/eudasm/asia/ images/maps/download/ID1000_16SO.jpg.

Pearson TRH, Brown SL and Birdsey RA. 2007. Measurement guidelines for the sequestration of forest carbon. USDA Forest Service. Northern Research Station. GTR 18.

Pemerintah Provinsi NTB. 2011. Peraturan Daerah Provinsi Nusa Tenggara Barat Nomor 3 Tahun 2010 tentang Rencana Tata Ruang Wilayah Provinsi Nusa Tenggara Barat Tahun 20092029. Mataram: Pemerintah Provinsi NTB.

Peters-Stanley M, Hamilton K and Yin D. 2012. State of the forest carbon markets 2012: Leveraging the landscape. Available at: http:// www.ecosystemmarketplace.com.

Peskett L, Schreckenberg K and Brown J. 2011. Institutional approaches for carbon financing in the forest sector: Learning lessons for $\mathrm{REDD}+$ from forest carbon projects in
Uganda. Environmental Science and Policy 14(2):216-29.

Phelps J, Webb EL and Agrawal A. 2010. Does REDD+ threaten to recentralize forest governance? Science 328:312-13.

Phelps J, Guerrero MC, Dalabajan DA, Young B and Webb EL. 2010. What makes a 'REDD+' country? Global Environmental Change 20(2):322-32.

Pirard R. 2012. Payments for Environmental Services (PES) in the public policy landscape: 'Mandatory' spices in the Indonesian recipe. Forest Policy and Economics 18:23-9.

Poffenberger M. 2009. Cambodia's forests and climate change: Mitigating drivers of deforestation. Natural Resources Forum 33(4):285-96.

Potapov P, Yaroshenko A, Turubanova S, Dubinin M, Laestadius L, Thies C, Aksenov D, Egorov A, Yesipova Y, Glushkov I, Karpachevskiy M, Kostikova A, Manisha A, Tsybikova EE and Zhuravleva I. 2008. Mapping the world's intact forest landscapes by remote sensing. Ecology and Society 13(2):51.

Potapov P, Turubanova S, Hansen MC, Adusei B, Broich M, Altstatt A, Mane L and Justice CO. 2012. Quantifying forest cover loss in Democratic Republic of the Congo, 20002010, with Landsat ETM+ data. Remote Sensing of Environment 122:106-116.

Pretty J. 1995. Participatory learning for sustainable agriculture. World Development 23(8):1247-63.

Putz FE and Redford KH. 2009. Dangers of carbonbased conservation. Global Environmental Change 19:400-1.

[RoI] Republic of Indonesia. 2007. Government Regulation No. 6/2007 Forest Arrangement and Establishment of Forest Management Plan as well as Forest Exploitation. Jakarta: Republic of Indonesia, (in Indonesian).

[RoI] Republic of Indonesia. 2009. Ministry of Forestry Regulation No. P.6/Menhut-II/2009 Establishment of Forest Management Unit. Jakarta: Republic of Indonesia, (in Indonesian).

[RoI] Republic of Indonesia. 2011. REDD+: Strategi National REDDD+. Final draft for online public disclosure. Jakarta: Indonesia. Available at: http://ukp.go.id/informasi-publik/ cat_view/21-redd.

Resosudarmo IAP. 2013. Lesson learnt from REDD+ initiatives in Indonesia: Preliminary findings. Presentation, Lombok REDD Workshop 2013 Proceeding, 5-6 December 2013. Seoul. 
Rosenqvist A, Milne A, Lucas R, Imhoff M and Dobson C. 2003. A review of remote sensing technology in support of Kyoto Protocol. Environmental Science and Policy 6:441-55.

Salovaara KJ, Thessler S, Malik RN and Tuomisto H. 2005. Classification of Amazonian primary rain forest vegetation using Landsat ETM+ satellite imagery. Remote Sensing of Environment 97:39-51.

Sandker M, Nyame SK, Förster J, Collier N, Shepherd G, Yeboah D, Blas DE, Machwitz M, Vaatainen S, Garedew E et al. 2010. REDD+ payments as incentive for reducing forest loss. Conservation Letters 3:114-121.

Sasaki N and Putz FE. 2009. Critical need for new definitions of 'forest' and 'forest degradation' in global climate change agreements. Conservation Letters 2(5):226-232.

Sasaki N and Yoshimoto A. 2010. Benefits of tropical forest management under the new climate change agreement-a case study in Cambodia. Environmental Science and Policy 13(5):384-92.

Sathaye J, Andrasko K and Chan P. 2011. Emissions scenarios, costs, and implementation considerations of REDD-plus programs. Environment and Development Economics 16:361-80.

Scharlemann JPW, Kapos V, Campbell A, Lysenko I, Burgess ND, Hansen MC, Gibbs HK, Dickson $\mathrm{B}$ and Miles L. 2010. Securing tropical forest carbon: The contribution of protected areas to REDD. Oryx 44(3):352-7.

Siregar CA and Ridwan M. 2014. Land Rehabilitation in Extreeme [sic] Zone: Learning from A/R CDM in East Lombok, Badan Litbang Kehutanan (FORDA). Ministry of Forestry, Jakarta.

Simula M. 2010. Analysis of REDD+ financing gaps and overlaps: REDD+ partnership. Available at: http://reddpluspartnership.org/65524/en/.

Skutsch MM and Ba L. 2010. Crediting carbon in dry forests: The potential for community forest management in West Africa. Forest Policy and Economics 12(4):264-70.

Smith J, Obidzinski K, Subarudi, Suramenggala I. 2003. Illegal logging, collusive corruption, and fragmented governments in Kalimantan, Indonesia. International Forestry Review 5(3):293-302.

Son Y, Park IH, Jin HO, Yi MJ, Kim DY, Kim RH and Hwang JO. 2004. Biomass and nutrient cycling of natural oak forests in Korea. 217-32. In Hong SK, Lee JA, Ihm BS, Farina A, Son Y, Kim ES and Choe CJ (eds). Ecological Issues in a Changing World. The Netherlands: Kluwer Academic Publishers.

Strassburg B, Turner RK, Fisher B, Schaeffer R and Lovett A. 2009. Reducing emissions from deforestation-the "combined incentives" mechanism and empirical simulations. Global Environmental Change 19(2):265-78.

Sukardi L. 2009. Desain Model Pemberdayaan Masyarakat Lokal dalam Pengelolaan Hutan Berkelanjutan (Kasus Masyarakat Sekitar Kawasan Hutan Taman Nasional Gunung Rinjani P. Lombok). Disertasi (tidak dipublikasikan). Sekolah Pasca Sarjana Institut Pertanian Bogor, Bogor.

Sunderlin WD, Larson AM, Duchelle AE, Resosudarmo IAP, Huynh TB, Awono A and Dokken T. 2013. How are REDD+ proponents addressing tenure problems? Evidence from Brazil, Cameroon, Tanzania, Indonesia, and Vietnam. World Development 55:37-52.

[SSSA] Soil Science Society of America. 1994. Methods of Soil Analysis. Part 2. Microbiological and biochemical properties. In Weaver RW, Angle S, Bottomley P, Bezdiecek D, Smith S, Tabatabai A, Wollum A, Mickelson SH, Bigham JM, eds. Soil Science Society of America Book, No 5. Soil Science Society of America

Tacconi L. 2003. Fires in Indonesia: Causes, cost and policies. CIFOR Occasional Paper No. 38. Bogor, Indonesia: Center for International Forestry Research.

Takwim AA. 2011. Cadangan Karbon Pada Pola Agroforestri Di Wilayah Seasot Narmada Kabupa Lombok Barat. Mataram:Fakultas Pertanian University of Mataram.

Thangata PH and Hildebrand PE. 2012. Carbon stock and sequestration potential of agroforestry systems in smallholder agroecosystems of sub-Saharan Africa: Mechanisms for 'reducing emissions from deforestation and forest degradation' (REDD+). Agriculture, Ecosystems \& Environment 158:172-83.

Thuy PT, Campbell BM, Garnett S, Aslin H and Minh Ha H. 2010. Importance and impacts of intermediary boundary organizations in facilitating payment for environmental services in Vietnam. Environmental Conservation 37(1):64-72.

Tottrup C. 2004. Improving tropical forest mapping using multi-date Landsat TM data and pre-classification image smoothing. 
International Journal of Remote Sensing 25(4):717-30.

Tucker CJ, Townshend JRG and Goff TE. 1985. African land-cover classification using satellite data. Science 227:369-75.

[UNFCCC] United Nations Framework Convention on Climate Change. 2005. Decision 16/CMP.1 on Land use, land-use change and forestry. Bonn:UNFCCC. Available at: http:// unfccc.int/methods/lulucf/items/6917.php.

[UNFCCC] United Nations Framework Convention on Climate Change. 2007. Reducing emissions from deforestation in developing countries: approaches to stimulate action.. 8-11. Bonn: UNFCCC. Available at: http://unfccc.int/ methods/lulucf/items/6917.php.

[UNFCCC] United Nations Framework Convention on Climate Change. 2009. Decision 4/CP. 15. Monitoring guidance for activities relating to reducing emissions from deforestation and forest degradation and the role of conservation, sustainable management of forests and enhancement of forest carbon stocks in developing countries. Bonn: UNFCCC. Available at: http:// unfccc.int/methods/lulucf/items/6917.php

[UNFCCC] United Nations Framework Convention on Climate Change. 2010. Decision 1/CP.16, The Cancun Agreements: Outcome of the work of the Ad Hoc Working Group on Long-term Cooperative Action under the Convention (FCCCI CP/2010/7/Add.1). Bonn: UNFCCC. Available at: http://unfccc.int/resource/docs/2010/cop16/ eng/07a01.pdf\#page $=2$

[UNFCCC] United Nations Framework Convention on Climate Change. 2013. Decision 9-15/CP.19, Action taken by the Conference of the Parties as its nineteenth session (Warsaw REDD+ Framework; FCCC/CP/2013/10/Add.1). Bonn: UNFCCC. Available at: http://unfccc.int/ resource/docs/2013/cop19/eng/10a01.pdf

[UNFCCC] United Nations Framework Convention on Climate Change. 2014. Definition of forest in Indonesia. Bonn: UNFCCC. Available at: http://cdm.unfccc.int/ DNA/bak/ARDNA.html?CID $=102$

[UNFCCC] United Nations Framework Convention on Climate Change. 2010. Decision 1/CP.16, The Cancun Agreements: Outcome of the Work of the Ad Hoc Working Group on Long-term Cooperative Action under the Convention (FCCC/CP/2010/7/Add.1). Bonn: UNFCCC. Available at: http://unfccc.int/ resource/docs/2010/cop16/eng/07a01. pdf\#page $=2$.
UN-REDD Programme. About REDD+. Geneva: UN-REDD Programme. Available at: http:// www.un-redd.org/AboutREDD/tabid/582/ Default.aspx.

[VCS] Verified Carbon Standard. 2012 (updated in 2013). VM0007 REDD + Methodology Modules $(R E D D+-M F), v 1.4$. Available at: http://v-c-s. org/methodologies/VM0007

[VCS] Verified Carbon Standard. 2012 (updated in 2013) Estimation of baseline carbon stock changes and greenhouse gas emissions from unplanned deforestation (BL-UP), v3.2. Available at: http:// v-c-s.org/methodologies/VM0007.

[VCS] Verified Carbon Standard. 2010. Estimation of baseline emissions from forest degradation caused by extraction of wood for fuel (BL-DFW), v1.0. Available at: http://v-c-s.org/methodologies/ VM0007.

Vieira ICG, Almeida AS, Davidson EA, Stone TA, Carvalho CJR and Guerrero JB. 2003. Classifying successional forests using Landsat spectral properties and ecological characteristics in eastern Amazônia. Remote Sensing of Environment 87(4):470-481.

Woodcock CE, Collins JB, Gopal S, Jakabhazy VD, Li X, Macomber S, Ryherd S, Harward VJ, Levitan J, Wu Y, et al. 1994. Mapping forest vegetation using Landsat TM imagery and a canopy reflectance model. Remote Sensing of Environment 50(3):240-254.

Wadi F. 2011. Role of Customary Institutions Semokan in Forest Resource Management in the Village Sukadana Bayan subdistrict, North Lombok. Mataram: Fakultas Pertanian Universitas Mataram.

Widiaryanto P. 2014. National Forestry Development: Mainstreaming KPH. Presentasi disampaikan pada pertemuan TOT Workshop bagi Tenaga Ahli Pendamping KPH (Expert Pool) Regional II - Jawa Bali Nusa Tenggara. Mataram.

[WWF] World Wildlife Fund. 2006. Dinamika Hubungan Kemiskinan dan Pengelolaan Sumberdaya Alam Pulau Kecil: Kasus Pulau Lombok. Mataram: WWF Indonesia - Nusa Tenggara Programme.

[WWF] World Wildlife Fund. 2008. Studi Analisis Hidrologis dan Perubahan Tutupan Lahan (Landuse land cover change) Kawasan Gunung Rinjani, Lombok. Mataram: WWF IndonesiaNusa Tenggara Programme.

Yudilastiantoro C and Sulistiono. 2008. Rights of Indigenous Peoples in Management "Community forest" in West Lombok NTB(in Indonesian). 
Prosiding Fungsi Kawasan Hutan Tahun 2008. Bogor:Pusat Penelitian Sosial ekonomi (Puslitsosek).

Zhuravleva I, Turubanova S, Potapov P, Hansen M,

Tyukavina A, Minnemeyer S, Laporte N, Goetz
S, Verbelen F and Thies C. 2013. Satellitebased primary forest degradation assessment in the Democratic Republic of the Congo, 2000-2010. Environmental Research Letters 8:024034. 

CIFOR Working Papers contain preliminary or advance research results on tropical forest issues that need to be published in a timely manner to inform and promote discussion. This content has been internally reviewed but has not undergone external peer review.

This paper explores opportunities for implementing activities for reducing emissions from deforestation and forest degradation (REDD) in areas with high poverty rates, rapid population growth and complex social dynamics. We focus on the potential role of localized Forest Management Units (or KPH) as an institutional partner, using the West Rinjani Protected Forest Management Unit (KPHL RB) on the island of Lombok, Nusa Tenggara Barat province, Indonesia as a case study. We relied on five essential elements for our analysis: (1) identification of land use changes, (2) estimation of average carbon stocks in forests and shrubland, (3) socioeconomic surveys to identify drivers of deforestation and forest degradation, (4) estimation of future reference emission levels, and (5) developing alternatives to reduce the rates of deforestation and forest degradation.

From 1990 to 2010, the forested area of Lombok decreased by $28.6 \%$ in the project area, representing a loss of 7130 ha (18.0\%), or 1 million $\mathrm{tC} \mathrm{ha}^{-1}$. Without intervention, carbon emission in the project area is conservatively estimated at 25.7 million metric $\mathrm{tCO}_{2}$ during the next 30 years. With the global average price for forest carbon offset at $\$ 7.8 /$ metric $\mathrm{tCO}_{2^{\prime}}$ we can expect a seven-fold return on investment. Our recommendations for this investment include: strengthening the $\mathrm{KPH}$ 's institutional and technical capacity, assuring de facto usufruct rights for local communities, bundling ecosystem services, cultivating local intermediaries, developing alternative energy sources and improving efficiency, and addressing the underlying drivers of deforestation through economic development, capacity building, and social investment.

\begin{tabular}{|c|c|c|}
\hline CGIAR & $\begin{array}{l}\text { RESEARCH } \\
\text { PROGRAM ON } \\
\text { Forests, Trees and } \\
\text { Agroforestry }\end{array}$ & $\begin{array}{l}\text { This research was carried out by CIFOR as part of the CGIAR Research Program on Forests, Trees } \\
\text { and Agroforestry (CRP-FTA). This collaborative program aims to enhance the management and } \\
\text { use of forests, agroforestry and tree genetic resources across the landscape from forests to farms. } \\
\text { CIFOR leads CRP-FTA in partnership with Bioversity International, CATIE, CIRAD, the International } \\
\text { Center for Tropical Agriculture and the World Agroforestry Centre. }\end{array}$ \\
\hline
\end{tabular}

